UNIVERSIDADE DE SÃO PAULO

ESCOLA DE ENFERMAGEM

ERLI MARTA REIS DA SILVA

ACIDENTE ESCORPIÔNICO NO MUNICÍPIO

DE SANTARÉM - PA: características

epidemiológicas e trajeto percorrido pelos pacientes

até o serviço de saúde

SÃO PAULO - SP 


\title{
ACIDENTE ESCORPIÔNICO NO MUNICÍPIO DE SANTARÉM - PA: características epidemiológicas e trajeto percorrido pelos pacientes até o serviço de saúde
}

\begin{abstract}
Versão corrigida da Dissertação apresentada ao Programa de Pós-Graduação em Mestrado Profissional em Enfermagem na Atenção Primária no Sistema Único de Saúde, da Escola de Enfermagem da Universidade de São Paulo, para obtenção de título de Mestra em Ciências da Saúde.
\end{abstract}

Área de concentração: Cuidado em Saúde na Atenção Primária

Orientador: Prof. Dr. Francisco Oscar de Siqueira França

\section{VERSÃO CORRIGIDA}

A versão original encontra-se disponível na Biblioteca da Escola de Enfermagem da Universidade de São Paulo e na Biblioteca Digital de Teses e Dissertações da Universidade de São Paulo.

São Paulo - SP 
AUTORIZO A REPRODUÇÃO E DIVULGAÇÃO TOTAL OU PARCIAL DESTE TRABALHO, POR QUALQUER MEIO CONVENCIONAL OU ELETRÔNICO, PARA FINS DE ESTUDO E PESQUISA, DESDE QUE CITADA A FONTE.

Assinatura: Earli Marta Reis da Sulva

Data:

\section{Catalogação na Publicação (CIP) \\ Biblioteca "Wanda de Aguiar Horta" \\ Escola de Enfermagem da Universidade de São Paulo}

Silva, Erli Marta Reis da

Acidente escorpiônico no município de Santarém- PA: características epidemiológicas e trajeto percorrido pelos pacientes até o serviço de saúde / Erli Marta Reis da Silva. São Paulo, 2017.

$99 \mathrm{p}$.

Dissertação (Mestrado) - Escola de Enfermagem da Universidade de São Paulo.

Orientador: Prof. Dr. Francisco Oscar de Siqueira França

Área de concentração: Cuidado em Saúde na Atenção Primária

1. Escorpiões. 2. Acidentes. 3. Acesso aos serviços de saúde. 4. Enfermagem. 5. Vulnerabilidade. I. Título. 
Nome: Erli Marta Reis da Silva. Título: Acidente escorpiônico no município de SantarémPA: características epidemiológicas e trajeto percorrido pelos pacientes até o serviço de saúde Dissertação apresentada ao Programa de Pós-Graduação em Mestrado Profissional em Enfermagem na Atenção Primária no Sistema Único de Saúde, da Escola de Enfermagem da Universidade de São Paulo, para obtenção de título de Mestra em Ciências da Saúde.

Aprovado em:

\section{Banca examinadora}

Prof. Dr. Instituição:

Julgamento: Assinatura:

Prof. Dr. Instituição:

Julgamento: Assinatura:

Prof. Dr. Instituição:

Julgamento: Assinatura: 


\section{DEDICATÓRIA}

Aos meus pais.

Benedito Pinto da Silva, meu eterno Babo, que no início da minha trajetória no mestrado pôde compartilhar comigo, ainda em vida, de sua alegria e orgulho pela minha conquista e hoje de um plano espiritual, sinto sua presença vibrante a me encorajar. Obrigado meu pai pelo privilégio de ter sido sua caçulinha.

E a minha mãe Maria Tereza Reis da Silva, mulher mais forte que já conheci em toda a minha vida, meu exemplo de fé, que ainda me proporciona o privilégio de ouvir sua voz forte, com seus conselhos sábios, bênçãos e incentivos. Obrigada por suas orações mãezinha, sem elas eu jamais teria tido forças e chegado até aqui. 


\section{AGRADECIMENTOS}

Este momento é muito especial, pois recordo de cada desafio para desenvolver a pesquisa e as disciplinas do Mestrado, entre viagens conturbadas a São Paulo, dificuldades finançeiras, a perda de meu pai querido, o compromisso de ser mãe, profissional, filha. E o quanto foi importante e necessário o envolvimento de pessoas especiais nesta trajetória.

Agradeço primeiramente a Deus, que ilumina e conduz minha caminhada.

À Escola de Enfermagem da USP, pela oportunidade de um aprendizado incrível, que transformou minha concepção de mundo.

À Biblioteca Wanda de Aguiar Horta da EEUSP, representada pelos funcionários que foram atenciosos e muito profissionais para atender minhas necessidades. Um especial agradecimento ao Carlos por sua simpatia e atenção.

À Secretária de Saúde de Santarém, ao Hospital Municipal de Santarém e ao setor de Urgência e Emergência que autorizaram a realização da pesquisa.

Ao Comitê de Ética e Pesquisa da EEUSP, pelas orientações fundamentais na submissão do projeto de pesquisa, que foi aprovado na primeira reunião, graças ao apoio técnico dos funcionários.

Ao meu orientador Prof. Dr. Francisco Oscar de Siqueira França, grande incentivador do conhecimento, que foi como um pai. Obrigada por sua paciência, e pela condução da pesquisa com suas ricas orientações, que foram fundamentais para o desenvolvimento da pesquisa. Foi uma honra ter sido orientada pelo senhor e ainda receber seus sábios conselhos.

À Prof. ${ }^{a}$ Dr. ${ }^{a}$ Maria Rita Bertolozzi, grande mulher, profissional, de um coração que transborda bondade. Obrigada pelo aprendizado nas disciplinas, pela coorientação do projeto de pesquisa e da pesquisa, por sua sensibilidade diante de minhas dificuldades e principalmente por acreditar no meu potencial.

A todos os Professores da Escola de Enfermagem da Universidade de São Paulo. Obrigada pelo rico desenvolvimento intelectual, conduzido com muita sabedoria nas disciplinas. 
Aos infectologistas João e Helena do Pronto Socorro Municipal, por participarem da coleta de dados referente ao exame clínico e por terem sido os informantes sobre a entrada das vítimas no PSM.

Aos participantes da pesquisa, que disponibilizaram suas ricas experiências e sabedorias.

A toda minha família, especialmente aos que fazem parte do meu dia a dia e acompanharam de perto essa jornada. Meus queridos sobrinhos irmãos, Andresa Maria, José Anderson, Andréa Dourado, Dilberto Júnior Seade e Angélica Dourado. A minha cunhada Edriane e à sobrinha Adriele, “a Didi”. E não poderia deixar de lembrar da tia Deusinha.

Ao meu filho do coração Lurian José, “o Ian”, mesmo de longe estava torcendo por $\operatorname{mim}$.

Ao meu filho Adriano Lucas, pelo seu amor, incentivo e apoio incondicional. Pelas nossas conversas confidenciais, entre mãe e filho, muitas vezes embaladas em nosso café paraense, de fim de tarde, que me servem de bálsamo e me fazem acreditar que os desafios são passageiros e os frutos servirão por toda uma vida.

As minhas filhas Ágatha Lís e Yasmim Pietra, que são minha alegria de viver, meus tesouros. O Mestrado foi pensando no melhor para vocês, minhas florzinhas.

A minha irmã Ana Tereza Reis. Obrigada maninha por todo o incentivo, pelo apoio emocional e financeiro que veio de forma tão generosa nos momentos mais difíceis dessa jornada. Obrigada, principalmente por ser referência em minha vida.

A minha irmã e mãe, mãe Célia, que me transfere energia positiva, fé e sabedoria. Obrigada pelas acolhidas em sua casa, quando eu chegava altas horas da noite em São Paulo, cansada, e era recebida com tanto amor e afeto.

Ao meu cunhado Seade Dourado, também por me acolher em sua casa, e muitas vezes me receber no aeroporto. Obrigada pela generosidade e apoio.

Ao meu cunhado Roberto Goulart, "o querido", que disponibilizou sua casa na Vila Madalena para que eu pudesse ter comodidade em minha estada em São Paulo. Obrigada também pelas orientações para andar sozinha em São Paulo. 
A querida Alessandra, que sempre me recebeu carinhosamente na Vila Madalena. Obrigada pelas conversas e por sua companhia.

A minha querida amiga Sheyla Mara Oliveira, seu otimismo e incentivo me fizeram embarcar nessa aventura inesquecível. Obrigada Sheylinha, por me instigar pro conhecimento, por suas orientações e apoio.

A minha colega Marilyn, companheira nas primeiras disciplinas do Mestrado. Obrigada pela troca de experiência e conhecimento.

A todos os meus colegas do Mestrado. Obrigada pela troca de experiência. Foi um privilégio conhecê-los.

A minha amiga Ana Cely. Obrigada pelo incentivo e apoio nas horas difíceis.

A minha queridíssima aluna de coração, Yamilles, essa flor de candura, que se disponibilizou em ser meu braço direito na formatação e ajustes finais, e pelo incentivo que tudo daria certo. Você foi um anjo encaminhado por Deus.

A todos os meus amigos e colegas de trabalho que me incentivaram e desejaram boa sorte nesta jornada.

Ao meu Dog “Beijamim”, meu brincalhão, companheiro nas madrugadas. 


\section{Canto Caboclo}

"é preciso voltar as horas até mil dias antes da nossa dor quem sabe receberemos proteção

a prevenção do tédio antes do remédio uma gota d'água antes da secura

quem sabe seus olhares nos vejam antes da cegueira serão necessárias mil horas antes da febre

para que seus barcos cheguem e seus acenos nos alcancem queremos a plenitude da vida, a morte não precisa se adiantar queremos a saúde do nosso povo e não a doença que podemos evitar canto a nossa vida simples, assim como as manhãs preparam as tardes e assim como as tardes anoitecem, precisamos do pão que os senhores escondem no breu dos nossos dias"

Consuelo de Paula 
Silva EMR. Acidente escorpiônico no Município de Santarém - PA: características epidemiológicas e trajeto percorrido pelos pacientes até o serviço de saúde [Dissertação]. São Paulo: Escola de Enfermagem, Universidade de São Paulo; 2017.

\section{RESUMO}

Introdução: O escorpionismo é reconhecido como um problema de saúde pública em alguns países em desenvolvimento devido à significativa incidência e gravidade, particularmente entre crianças e idosos com comorbidades. No Brasil, estima-se que ocorram cerca de 58.000 acidentes com mais de 80 óbitos por ano, o que representa uma incidência anual aproximada de 30 casos/100.000 habitantes/ano. Justifica-se, portanto, o presente estudo, tendo em vista que, no Município de Santarém-PA, na Amazônia, há dificuldade de acesso aos serviços de saúde pela população local, devido à extensão territorial da região. Objetivo: Analisar como se processa a ocorrência de acidente escorpiônico no Município de Santarém-PA. Método:O estudo foi observacional, exploratório, prospectivo, descritivo e qualitativo. Foram sujeitos do estudo, 19 pacientes vítimas de acidente escorpiônico atendidos no PSM, no período de Novembro de 2016 a Fevereiro de 2017. Dados relativos às características pessoais, de condições de vida e de trabalho foram extraídos dos prontuários e confirmados por ocasião das entrevistas realizadas enquanto estiveram internados na unidade hospitalar. Também foram levantados dados clínicos. Utilizou-se de instrumento para a captura dos dados. Os procedimentos éticos foram resguardados.Resultados: Em relação à caracterização dos sujeitos, verificou-se que dos 19 entrevistados 14 (73,7\%) eram do sexo masculino. Quanto à faixa etária, $5(26,3 \%)$ tinham idade entre 5 e 10 anos, e 2 (10,6\%) entre 11-20 anos, os demais eram adultos ente 21 e 60 anos. Em relação ao tempo de estudo, mesmo levando em consideração os sujeitos menores de idade, alguns dos sujeitos adultos possuíam baixa escolaridade, sendo o maior número de anos de estudo entre 8 e 10 anos, em 7 (36,8\%) dos entrevistados. A maior parte dos acidentes ocorreu na zona rural: $13(68,5 \%)$. Quanto aos sintomas, a dor local foi relatadapor 18 (94,7\%); a sensação de choque por $18(94,7 \%)$. O tempo de chegada à unidade hospitalar, após a picada, foi maior que uma hora em $15(78,9 \%)$ dos casos. A análise qualitativa dos depoimentos revelou cinco Temas: Situação em que ocorreu o acidente escorpiônico; Trajetória percorrida pelo paciente até o tratamento;Providências após a ocorrência do acidente; Manifestações clínicas apresentadas pelas vítimas dos acidentes escorpiônicos; $\mathrm{O}$ que foi feito com o escorpião (lacrau).Estes temas evidenciam a experiência dos sujeitos no manejo do agravo; a forma como se processa o percurso até a unidade de atendimento, evidenciando falhas no acesso e vulnerabilidade programática; e algumas características relacionadas ao modo de vida dos indivíduos. Conclusão: Verificou-se dificuldade no acesso aos serviços de saúde, relacionada à distância geográfica entre as comunidades rurais e o Município de Santarém, onde há o tratamento específico para o acidente escorpiônico, além da necessidade de percorrer várias unidades de saúde até a obtenção do tratamento adequado; a severidade das manifestações locais e sistêmicas; o desconhecimento da população local acerca do manejo apropriado do agravo escorpiônico; e afalta de informações a respeito de ações de prevenção e de tratamento correto. Propõe-se, portanto, uma cartilha para ser utilizada junto às comunidades, para instrumentalizá-las sobre as melhores ações a serem adotadas na prevenção e por ocasião do acidente.

Palavras-chave: escorpião, acidente, acesso aos serviços de saúde, enfermagem, vulnerabilidade. 


\section{Silva EMR.Scorpionic Accident in the Municipality of Santarém - PA: epidemiological characteristics and access of the patients to the health service [Dissertation]. São Paulo: School of Nursing, University of São Paulo; 2017.}

Introduction: Scorpionism is recognized as a public health problem in some developing countries due to its significant incidence and severity especially among children and elderly with comorbidities. It is estimated that about 58,000 accidents occur in Brazil with over 80 deaths per year, representing an approximate annual incidence of 30 cases $/ 100,000$ inhabitants per year. The present study is justified since in the Municipality of Santarém-PA, in the Amazon region, there is great difficulty of access to health services by the local population due to the territorial extension. Objective: Analyze how the scorpion accident occurs in the municipality of Santarem-PA. Method:The study was observational, exploratory, prospective, descriptive and qualitative. Nineteen patients who were victims of scorpionic accidents were included in the study. They were treated at the PSM during November 2016 through February 2017. Data on personal characteristics and living and working conditions were extracted from the medical records and confirmed at the time of the interviews while the patients were at the hospital. Clinical data was also collected. An instrument was used to collect the data. The ethical procedures were preserved. Results: In relation to the characterization of the subjects, it was verified that 14 out of the 19 interviewed (73.7\%) were male. As for the age group 5 (26.3\%) were aged between 5 and 10 years old and $2(10.6 \%)$ between 11 and 20 years old. The others were adults ranging from 21 and 60 years. Regarding the schooling, taking into consideration even the underage subjects, the majority of the adult subjects had low schooling and 7 (36.8\%) with the greatest number of years of schooling ranged only from 8 to 10 years. Most accidents occurred in the rural area $13(68.5 \%)$. Regarding to the symptoms, the local pain was pointed out by $18(94.7 \%)$; the shock sensation by $18(94.7 \%)$. The time of arrival at the hospital after the accident was over one hour in 15 (78.9\%) cases. The qualitative analysis of the testimonies revealed five themes: Situation in which the scorpionic accident occurred; Trajectory traveled by the patient to the treatment site, Measures taken after the occurrence of the accident; Clinical manifestations presented by the patients; What had been done with the scorpion (lacrau). The themes revealed evidence of the experience by which the subjects dealt with the situation; the flow of the trajectory to the service unit evidencing access failures and programmatic vulnerability; and some characteristics related to the way of life of individuals. Conclusion:There was difficulty in accessing health services, related to the geographical distance between rural communities and the Municipality of Santarém, where there is the specific treatment for the scorpionic accident, as well as the need to go through several health units until obtaining the treatment; the severity of local and systemic manifestations; the lack of knowledge of the local population about the proper management of the scorpionism; preventive actions and the lack of information regarding to the correct treatment. Therefore, it is proposed a hornbook to be used at the communities, to instrumentalize the population on the best actions to be taken for prevention and after the accident.

Key words: scorpion, accident, access to health services, nursing, vulnerability. 


\section{LISTA DE ILUSTRAÇÕES}

Figura1 -Morfologia externa do escorpião.

Figura2- T. Serrulatus

Figura3- T. Bahiensis

Figura4 - T. Stigmurus

Figura5- T. paraenses(T. obscurus)

Quadro1 - Classificação dos acidentes escorpiônicos quanto à gravidade, manifestações clínicas e tratamento específico

Figura6- Pronto Socorro Municipal de Santarém(PSM)

Figura 7-Mapa do Estado do Pará

Quadro2 - Perfil Sócio-demográfico dos sujeitos do estudo Santarém-PA, 2017

Quadro 3- Perfil de condições de vida e trabalho dos sujeitos do estudo. Santarém-PA, 2017.

Quadro4- Distribuição dos sujeitos do estudo segundo manifestações clínicasmencionadas. Santarém-PA, 2017

Quadro 5- Distribuição dos sujeitos do estudo segundo manifestações sistêmicas. SantarémPA, 2017.

Quadro6- Distribuição dos sujeitos do estudo segundo manifestações sistêmicas. SantarémPA

Figura8 - Modelo das categorias dos Determinantes Sociais da Saúde

Figura 9- Comércio de medicamentos caseiros e Fitoterápicos (Mercadão 2000). SantarémPA, 2017

Figura 10 -Comércio de medicamentos caseiros e Fitoterápicos (Mercadão 2000). SantarémPA, 2017

Figura 11 -Medicamento Fitoterápico comercializado para tratamento de picada de escorpião (Mercadão 2000 Santarém-PA, 2017 


\title{
LISTA DE SIGLAS
}

\author{
AIDS - Acquired Immunodeficiency Syndrome \\ CEP — Comitê de Ética em Pesquisa \\ COREME - Comissão de Residência Médica \\ CNRM - Comissão Nacional de Residência Médica \\ CNS - Conselho Nacional de Saúde \\ DSS - Determinantes Sociais da Saúde \\ HRBA - Hospital Regional do Baixo Amazonas \\ HMS - Hospital Municipal de Saúde \\ IBGE - Instituto Brasileiro de Geografia e Estatística \\ PSM — Pronto Socorro Municipal \\ SEMSA - Secretaria Municipal de Saúde \\ UTI — Unidade de Terapia Intensiva \\ UBS — Unidade Básica de Saúde \\ UPA — Unidade de Pronto Atendimento \\ UEPA - Universidade do Estado do Pará
}




\section{SUMÁRIO}

Erro! Indicador não definido.INTRODUÇÃOErro! Indicador não definido. .17

1.1CARACTERÍSTICAS GERAIS DOS ESCORPIÕESErro! Indicador não definido. .17

$\begin{array}{llll}1.2 T A X O N O M I A & \text { DOS } & \text { ESCORPIÕESErro! } & \text { Indicador }\end{array}$

1.3ESCORPIÕES DE IMPORTÂNCIA MÉDICA NO MUNDO E NO BRASILErro! Indicador não

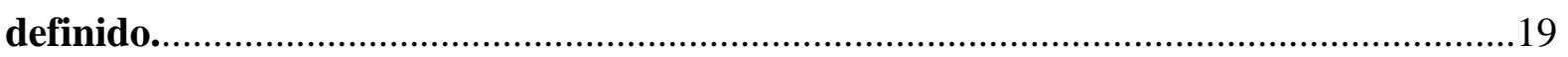
1.4EPIDEMIOLOGIA DOS ACIDENTES ESCORPIÔNICOS NO MUNDO E NO BRASIL.Erro! Indicador não

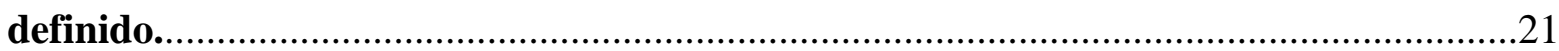

1.5ESCORPIONISMO NA AMAZÔNIA E EM SANTARÉM-PAErro! Indicador não definido. 22

1.6MECANISMO DE AÇÃO DO VENENOErro! Indicador não definido. .22

1.7ESCORPIONISMO:

CLÍNICA

$\mathbf{E}$

TRATAMENTO Erro! Indicador não definido.....23

1.8SUPORTE ÀS CONDIÇÕES VITAIS DAS VÍTIMAS DE ESCORPIONISMO......25

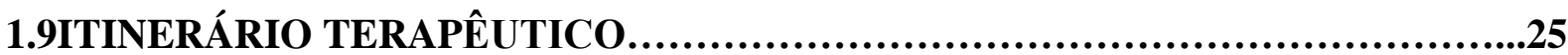

1.10VULNERABILIDADE: CONCEITO.....................................................................28

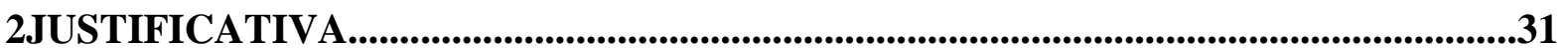

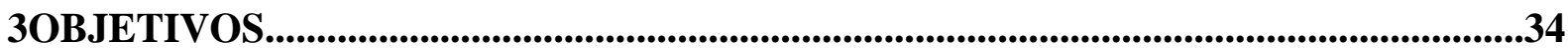

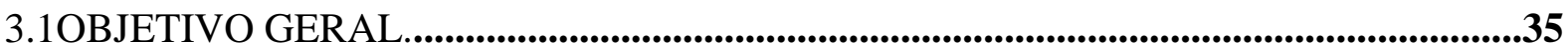

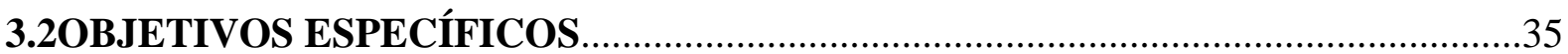

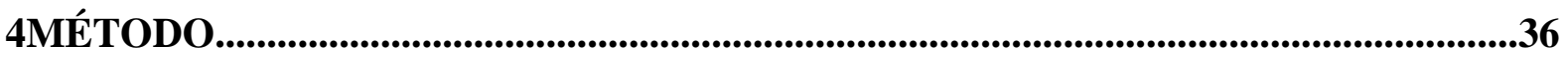

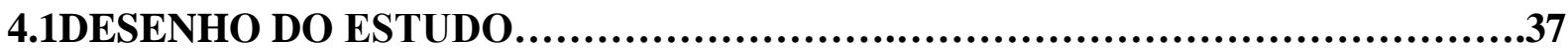


4.2PERÍODO DE COLETA DE DADOS

4.4SUJEITOS DO ESTUDO........................................................................................................40

4.5INSTRUMENTOS DE COLETA DE DADOS ………………………………...........

4.6 PROCEDIMENTOS NA COLETA DE DADOS …………………………….............

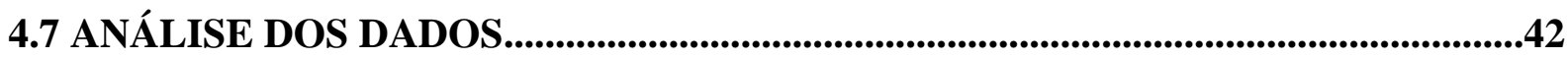

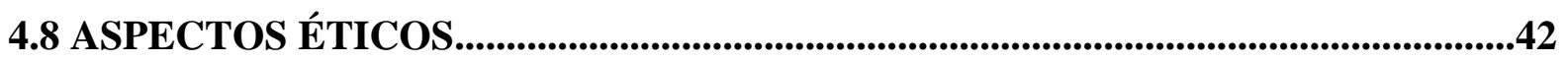

5. RESULTADOS E DISCUSSÃO................................................................................43

5.1 CARACTERIZAÇÃO SOCIOECONÔMICA E DEMOGRÁFICA DOS SUJEITOS, SITUAÇÃO EM QUE OCORREU O ACIDENTE E MANIFESTAÇÕES LOCAIS E SISTÊMICAS..........................................................................................................44

5.2OS DEPOIMENTOS DOS SUJEITOS..............................................................................58

6CONSIDERAÇÕES FINAIS......................................................................................75

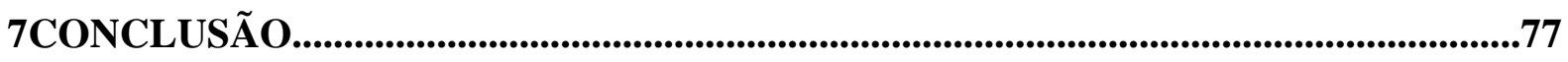

8PROPOSTA DE INTERVENÇÃO............................................................................................80

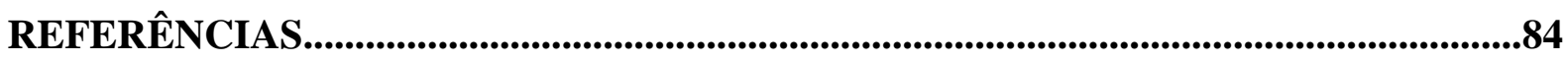

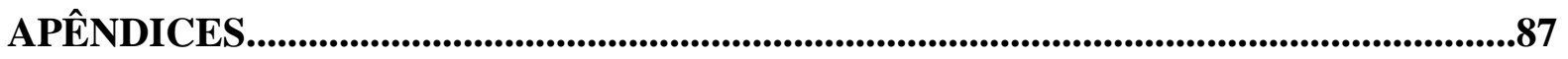

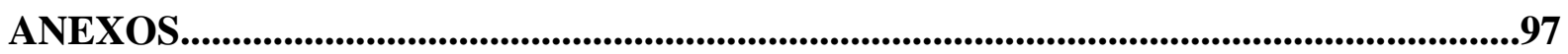




\section{INTRODUÇÃO}

\section{INTRODUÇÃO}

\subsection{CARACTERÍSTICAS GERAIS DOS ESCORPIÕES}

Os escorpiões (Scorpiones), também conhecidos popularmente como Lacraus na região Amazônica, surgiram há 450 milhões de anos em ambiente marinho; sendo descritos em ambiente terrestre de 325 à 350 milhões de anos (POLIS, 1990).

Estes artrópodes apresentam ampla distribuição geográfica, estando distribuídos em todos os continentes, com exceção da Antártica (SOLEGLAND; FET, 2003). Os países que apresentam maior diversidade de escorpiões no mundo são: Brasil, Equador, Colômbia e Peru (COSTA, 2012).

Os escorpiões podem ser encontrados nos mais variados ambientes e esconderijos, como linhas de trem, construções, e em moradias. A maioria das espécies possui hábitos noturnos e os animais são ativos o ano todo, carnívoros e predadores de uma série de outros pequenosanimais.Têm diversos predadores, como: camundongos, morcegos, galinhas, corujas, quatis, sapos, formigas, lacraias, algumas aranhas, macacos, lagartos e até mesmo os próprios escorpiões (FUNDAÇÃO NACIONAL DE SAÚDE, 2009).

O corpo do escorpião é dividido em:

$\checkmark$ Carapuça (prossoma), que é formada por um par de quelíceras (que trituram os alimentos), um par de pedipalpos (pinças ou mãos) e quatro pares de pernas.

$\checkmark$ Abdômen (opistossoma), composto por:

Tronco (Mesassoma),onde se encontram o opérculo genital, apêndices sensoriais e espiráculos, que são aberturas externas dos pulmões.

Cauda (Metassoma), que possui na extremidade o telson, de onde se origina o ferrão, usado para inocular sua peçonha (FUNDAÇÃO NACIONAL DE SAÚDE, 2009). 
A Figura 1 apresenta a morfologia de um escorpião, com sua respectiva divisão: carapuça e abdômen (tronco e cauda).

Figura 1: Morfologia externa do escorpião. 1. Vista Dorsal, 2. Vista Ventral

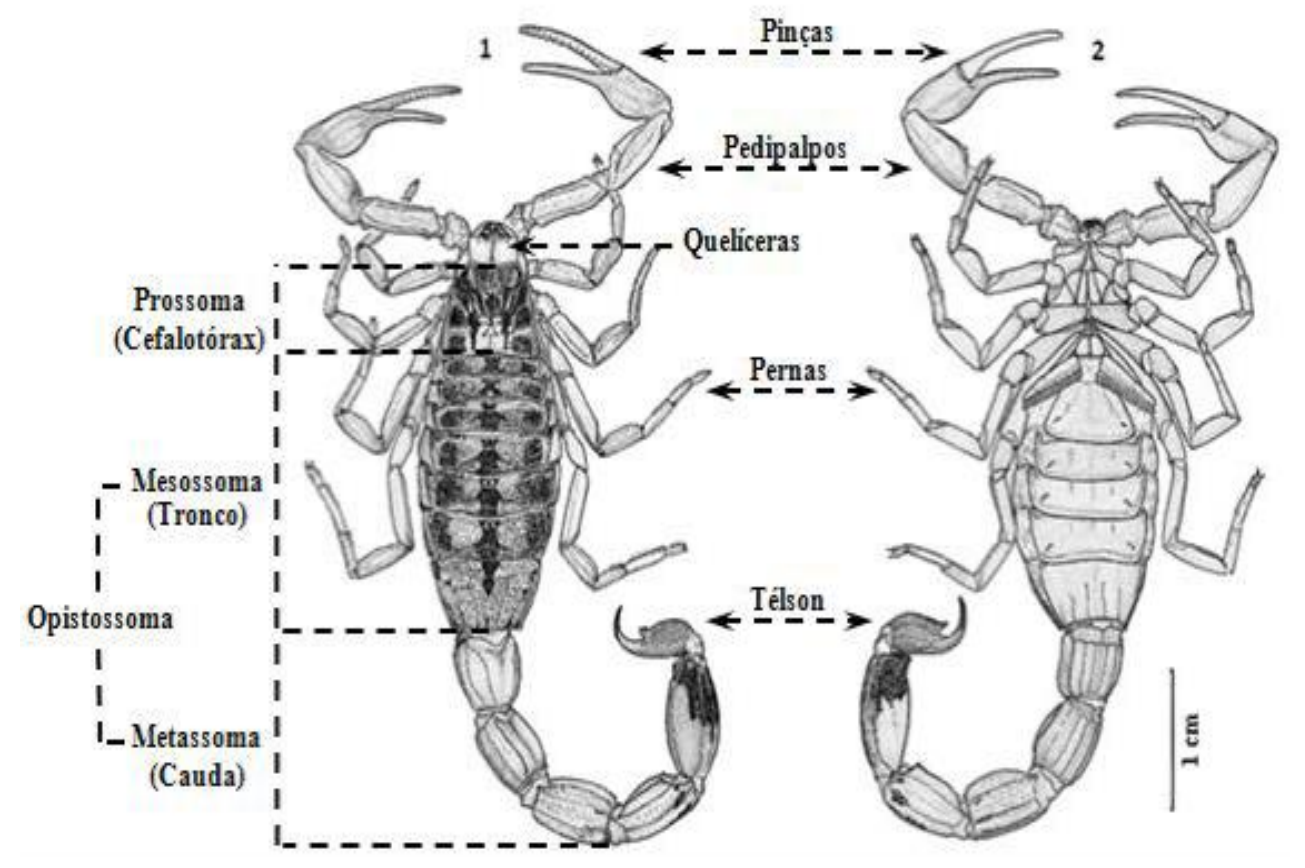

Fonte: Ministério da Saúde - Brasília/DF, 2009.

\subsection{TAXONOMIA DOS ESCORPIÕES}

O Brasil é o maior país tropical do mundo, apresentando grande variedade de clima, relevo, solos e vegetação, que formam diferentes biomas e ecorregiões (AB'SABER, 2003). Apresenta um ecossistema diversificado, sendo o que apresenta maior número de espécies, estimado em 1,8 milhões; deste total, são conhecidos apenas 10\%. Os aracnídeos, por exemplo, correspondem somente a 5.600 a 6.500 espécies (LEWINSOHN et al., 2005). 
A fauna de escorpiões é uma das mais estudadas na atualidade, sendo descritos novos táxonos desde 1970 (LOURENÇO; EICKSTEDT, 2009). A família Buthidae apresenta 82 espécies distribuídas em 8 gêneros, sendo o gênero Tityus o que apresenta o maior número de espécies: 54 (BRAZIL; PORTO, 2010).

Estudos biológicos de escorpiões são necessários, embora sejam um grande desafio, devido à escassez de profissionais habilitados em pesquisar estes animais (LOURENÇO; EICKSTEDT, 2009).

A produção científica sobre o escorpionismo na Amazônia, assim como sobre a diversidade de espécies, epidemiologia, clínica, e, principalmente, do manejo do paciente, ainda requer muitos avanços. Faz-se necessário o desenvolvimento de estudos que possam ampliar o conhecimento de profissionais da área da saúde e da população em geral sobre estes organismos (COSTA, 2012).

\subsection{ESCORPIÕES DE IMPORTÂNCIA MÉDICA NO MUNDO E NO BRASIL}

Atualmente, existem 1.600 espécies conhecidas no mundo; destas, 25 são consideradas de interesse em saúde (FUNDAÇÃO NACIONAL DE SAÚDE, 2009).

Entre as de maior importância médica, em território brasileiro, por causarem envenenamentos que podem evoluir para quadros graves ou até mesmo causar óbito, destacam-se: T. serrulatus, além do T. bahiensis, do T. obscurus, e do T. stigmurus (BRAZIL; PORTO, 2010). Na Amazônia são encontradas muitas espécies, destacando-se o T. obscurus, o T. silvestris e o T. metuendus, que também estão presentes na cidade de Santarém-PA (PARDAL et al., 2014).

O T. serrulatus, conhecido como escorpião amarelo (Figura 2), é a principal espécie causadora de acidentes graves, com registros de óbitos, particularmente em crianças. Este animal possui pernas e cauda amarelo-clara, e o tronco escuro, e mede até $7 \mathrm{~cm}$ de comprimento. Possui boa adaptação a ambientes urbanos, com rápida proliferação (FUNDAÇÃO NACIONAL DE SAÚDE, 2009).

Figura 2: T. serrulatus (Escorpião amarelo) 


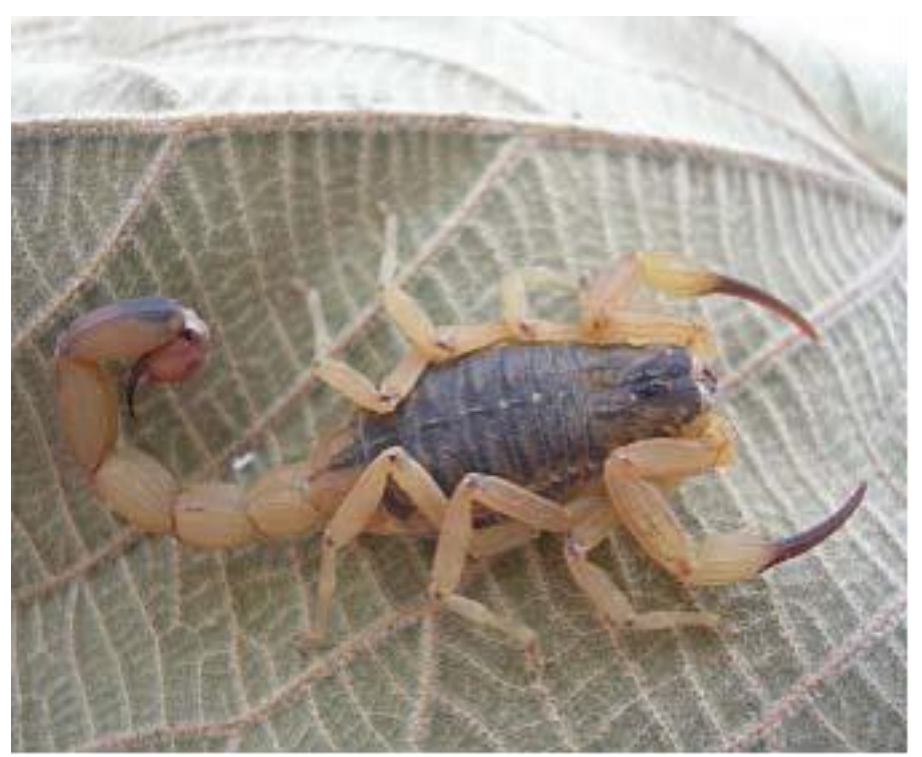

Fonte: Ministério da Saúde - Brasília/DF, 2009.

Também merece destaque o T. bahiensis, conhecido como escorpião marrom ou preto (Figura 3), maior causador de acidentes em São Paulo; a seguir o T. stigmurus, escorpião amarelo do Nordeste (Figura 4) sendo o maior causador de acidentes nesta região e, por último, o T. paraensis(Figura 5), denominado atualmente por T. obscurus, o escorpião preto da Amazônia (FUNDAÇÃO NACIONAL DE SAÚDE, 2009).

Figura 3: T. bahiensis

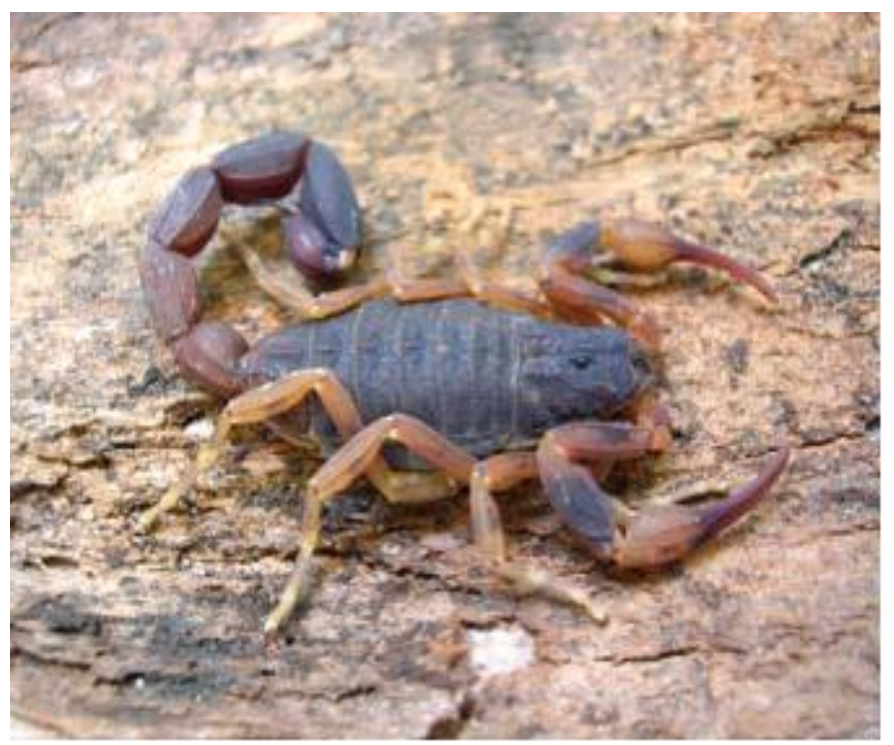

Fonte: Ministério da Saúde - Brasília/DF, 2009.

Figura 4: T. stigmurus 


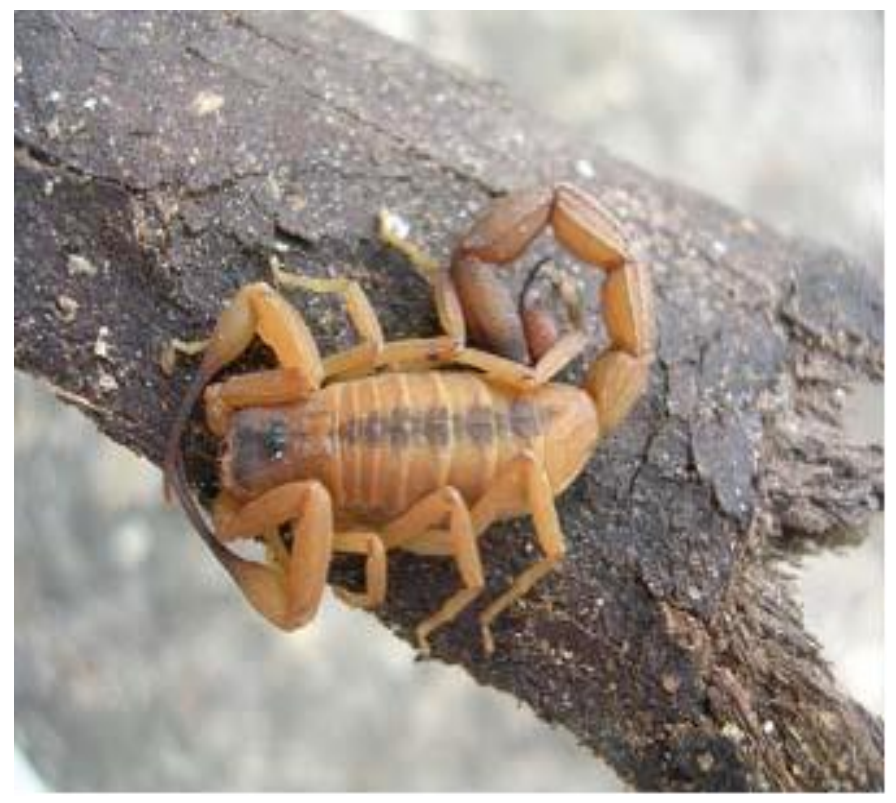

Fonte: Ministério da Saúde - Brasília/DF, 2009.

Figura 5: T. Paraenses(T. obscurus).

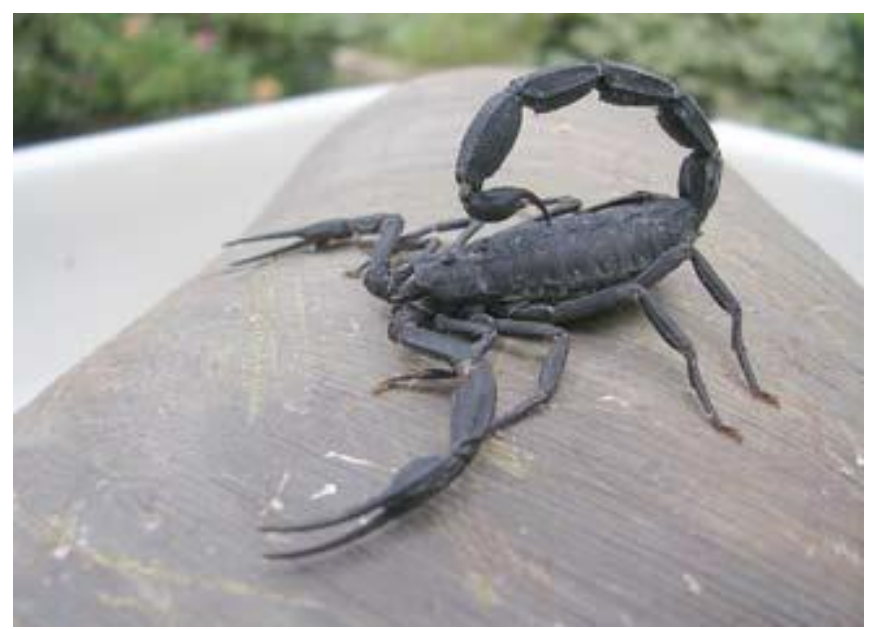

Fonte: Ministério da Saúde - Brasília/DF, 2009.

\subsection{EPIDEMIOLOGIA DOS ACIDENTES ESCORPIÔNICOS NO MUNDO E NO BRASIL}

No Brasil, há três espécies de escorpiões de gênero Tityus, responsáveis por acidentes humanos: o T. serrulatus (escorpião amarelo), oT. baienses (escorpião marrom), e o $T$. stigmurus, sendo o T. serrulatuso causador da maioria dos casos graves (CUPO et al., 2015). 
Aproximadamente 2,3 bilhões de pessoas vivem em áreas de risco, por habitarem áreas com a presença de escorpiões de importância médica e ocorrem 1,2 milhões de acidentes anuais, sendo que, dentre as regiões afetadas, encontra-se a América do Sul. A epidemiologia no mundo apresenta muitas especificidades e peculiaridades, em cada região, devido às importantes variações geográficas, o que interfere na definição da gravidade do acidente nas diversas áreas de risco (CHIPPAUX;GOYFFON, 2008).

A picada de escorpião é um acidente comum na infância, devido à maior exposição desse grupo. Para Horta et al. (2007),nesta faixa etária há um risco maior de gravidade. Nesse contexto, é essencial avaliar precocemente a gravidade do envenenamento para que se estabeleça de imediato o tratamento (CHIPPAUX; GOYFFON, 2008).

Dados obtidos do Sistema de Informação de Agravos e Notificação, em 2013, mostram que foram notificados, no Estado do Pará, 242 casos de acidentes por escorpião, sendo que destes, 53 ocorreram no Município de Santarém e, em 31 destes, o tempo entre o acidente e o atendimento médico foi maior que 12 horas (SINAN, 2016).

Em 2014, foram notificados 144 acidentes por escorpião no mesmo Município e, destes, em 7o período de tempo entre o momento do acidente e o atendimento médico, foi maior do que 24 horas (SINAN, 2016).

\subsection{ESCORPIONISMO NA AMAZÔNIA E EM SANTARÉM-PA}

Na Amazônia o escorpionismo é um reconhecido problema de saúde pública (PARDAL et al., 2003). O escorpião é o artrópode que mais ocasiona acidentes nos pacientes atendidos no Centro de Informações Toxicológicas de Belém.

Em Santarém, localizada à margem direita do Rio Tapajós, são atendidas pessoas vítimas de acidentes por escorpião, procedentes do próprio Município, de distritos, de comunidades ribeirinhas, do planalto, como Alter-do-Chão, localizada à $30 \mathrm{~km}$ do Municípioe até mesmo de outros municípios circunvizinhos.

Nesta região, a assistência oferecida aos pacientes apresenta muitas dificuldades a serem superadas, evidenciando que a população não tem acesso a serviços dotados de equipamentos e de equipes de saúde com competência para o manejo do acidente segundo a gravidade. Outra dificuldade refere-se às grandes distâncias que a população precisa percorrer para chegar a uma unidade de saúde. 
No Estado do Pará, a espécie de escorpião mais frequentemente responsável por envenenamento é o Tityus obscurus, anteriormente conhecido como $T$. paraensis e $T$. cambridge (PARDAL et al., 2003). Em análise das diversas regiões do Estado verificou-se que a maior frequência de casos moderados e graves notificados, nos anos de 1998 a 2005, encontrava-se no Baixo Amazonas, Nordeste Paraense e região Metropolitana de Belém (NETO etal., 2008).

\subsection{MECANISMO DE AÇÃO DO VENENO}

O veneno do escorpião é uma composição complexa de proteínas de baixo peso molecular, aminoácidos e sais, produzidas e localizadas no télson, que atuam em sítios específicos dos canais de sódio e de potássio de membranas celulares (CUPO, 2015).

As toxinas escorpiônicas que atuam no canal de $\mathrm{Na}+$ causam despolarização intensa e prolongada, conduzindo à excitação neuronal. Estimulam as terminações nervosas pósganglionares do sistema nervoso simpático e parassimpático e da medula supra-renal, induzindo a liberação de acetilcolina, adrenalina e noradrenalina (CUPO, 2015). A composição do veneno pode variar de acordo com a área habitada e hábitos alimentares destes animais (TORREZ et al., 2015).

\subsection{ESCORPIONISMO: CLÍNICA E TRATAMENTO}

O acidente ocorre através da inoculação do veneno nas vítimas, pelo aparelho inoculador (ferrão) (PARDAL et al., 2003).

Diversos estudos sobre o escorpionismo descrevem a severidade dos casos ocorridos em populações selecionadas, assim como as manifestações clínicas mais frequentes, descritas como alterações locais e sistêmicas.

A gravidade dos acidentes escorpiônicos depende de fatores relacionados à espécie e tamanho do escorpião, à quantidade de veneno inoculado, à massa corporal e à sensibilidade do paciente ao veneno. Além disso, outros fatores, como o tempo decorrido entre a picada e a administração do soro antiescorpiônico e o monitoramento dos sinais vitais, podem interferir na evolução e no prognóstico (ALBUQUERQUE et al., 2009).

Após o acidente é necessário adotar algumas medidas imediatamente, conforme as orientações abaixo (FUNDAÇÃO NACIONAL DE SAÚDE, 2009). 
O que se deve fazer?

$\checkmark$ Limpar o local com água e sabão;

$\checkmark$ Procurar orientação médica imediatamente na Unidade Básica de Saúde (UBS) ou no Hospital mais próximo;

$\checkmark$ Capturar o animal se for possível, e levá-lo ao serviço de saúde paraidentificar a espécie e, assim, auxiliar no diagnóstico;

O que não se deve fazer?

$\checkmark$ Amarrar ou fazer torniquete;

$\checkmark$ Aplicar qualquer tipo de substância sobre o local da picada;

$\checkmark$ Cortar, perfurar ou queimar o local da picada.

Oferecer bebida alcoólica ao acidentado, ou outros líquidos, como álcool, gasolina, querosene.

Os acidentes escorpiônicos são classificados, para fins terapêuticos e prognóstico, com base nas manifestações clínicas, conforme o Quadro 1 (Ministério da Saúde, 2001).

Quadro1: Classificação dos acidentes escorpiônicos quanto à gravidade, manifestações clínicas e tratamento específico

\begin{tabular}{|c|l|l|}
\hline $\begin{array}{c}\text { CLASSIFICAÇÃO } \\
\text { DO QUADRO }\end{array}$ & \multicolumn{1}{|c|}{$\begin{array}{c}\text { MANIFESTAÇÕES } \\
\text { CLÍNICAS }\end{array}$} & \multicolumn{1}{c|}{ TRATAMENTO } \\
\hline \multirow{2}{*}{ LEVE } & $\begin{array}{l}\text { Apenas quadro local: dor, } \\
\text { eritema, parestesia, sudorese; } \\
\text { Ocasionalmente: náusea, } \\
\text { vômito, agitação e taquicardia } \\
\text { discretas;relacionadas à dor. }\end{array}$ & $\begin{array}{l}\text {-Observação clínica por } \\
\text { 6horas; } \\
\text {-Analgésico e compressa } \\
\text { local quente e/ou bloqueio } \\
\text { anestésico local. }\end{array}$ \\
\hline
\end{tabular}




\begin{tabular}{|c|l|l|}
\hline \multirow{2}{*}{ MODERADO } & $\begin{array}{l}\text { Quadro local associado a } \\
\text { algumas das seguintes } \\
\text { manifestacões sistêmicas de } \\
\text { pequena intensidade:sudorese, } \\
\text { náuseas, alguns episódios de } \\
\text { vômitos, } \uparrow \text { ou } \downarrow \text { FC, } \uparrow \text { PA, } \\
\text { (CHIPPAUX; GOYFFON, } \\
\text { 2008). }\end{array}$ & $\begin{array}{l}\text {-SAEsc: 3 ampolas, IV } \\
\text { - Internação; } \\
\text { local quente e/ou bloqueio } \\
\text { anestésico local. }\end{array}$ \\
\hline $\begin{array}{l}\text { Manifestacões sistêmicas } \\
\text { intensas:inúmeros episódios de }\end{array}$ & $\begin{array}{l}\text { - Internação; } \\
\text { vômitos,sudorese profusa, } \uparrow \text { ou } \downarrow \\
\text { FC, } \uparrow \text { ou } \downarrow \text { PA, sialorreia, } \\
\text { agitação alternada com } \\
\text { sonolência, taquidispneia, } \\
\text { priapismo, convulsões, } \\
\text { insuficiência cardíaca, Edema } \\
\text { Pulmonar Agudo. }\end{array}$ & $\begin{array}{l}\text { - Monitorização contínua; } \\
\text { - Cuidados de Terapia } \\
\text { Intensíva se necessário; } \\
\text {-Analgésico e compressa } \\
\text { local quente e/ou bloqueio } \\
\text { anestésico local. }\end{array}$ \\
\hline
\end{tabular}

Fonte:Ministério da Saúde, 2001. Legenda: IV: Intravenoso; SAA: Soro Antiaracnídico; SAE: Soro Antiescorpiônico.

\subsection{SUPORTE Às CONDIÇÕES VITAIS DAS VÍTIMAS DE ESCORPIONISMO}

O manejo clínico e farmacológico às vítimas de escorpionismo é de fundamental importância, principalmente nos casos graves, como ressaltam Cupo et al. (2015, p. 492):

Todos os casos graves de escorpionismo devem ser monitorizados continuamente quanto à frequência cardíaca e respiratória, pressão arterial, oxigenação, equilíbrio ácido-base e estado de hidratação. Traçado eletrocardiográfico, contínuo ou de forma seriada, é necessário para detecção de arritmias e outras alterações cardíacas.

Destaca-se aqui o papel e o compromisso dos profissionais de saúde que são responsáveis pelo atendimento das vítimas de picada de escorpião, tanto em relação àquelas sob observação quanto às que necessitam de internação. 
As pessoas que apresentam quadro moderado ou grave exigem cuidados rigorosos, por isso, o monitoramento contínuo dos sinais vitais e de possíveis complicações é indispensável, para que seja possível conduzir o tratamento de forma prudente. O controle dos sinais e sintomas, por exemplo, é imprescindível para controlar possíveis alterações e tomar condutas ágeis e viáveis para a estabilidade do paciente.

É fundamental implementar medidas concomitantemente ao tratamento estabelecido, de maneira a fornecer suporte às condições vitais do paciente, para minimizar os sintomas secundários à ação do veneno. Todo paciente que chegar à unidade de saúde deverá permanecer em observação por 6 horas, em caso leve; por 24 a 48 horas em casos moderados; e os casos graves devem ser encaminhados para unidade de terapia intensiva (CIRUFFO etal., 2012).

\subsection{ITINERÁRIO TERAPÊUTICO}

O Itinerário Terapêutico (IT) possui várias denominações, dentre estas, "trajetória terapêutica", "processos terapêuticos", "caminhos percorridos", "procura de cuidados em saúde", "trajetória bibliográfica", "peregrinação", evidenciando sua polissemia. A maioria dos estudos limita a definição a apenas dois eixos. O primeiro na perspectiva individual, em que o sujeito escolhe e traça seu itinerário. O segundo, em que o meio cultural determina as escolhas do sujeito (BELLATO et al., 2008).

Analisar o Itinerário Terapêutico significa ir além de identificar serviços disponíveis, mas inclui seus modelos explicativos e o uso das instituições de saúde pelos indivíduos. Compreender este complexo processo de escolha significa escolher um tratamento levando em consideração o contexto sociocultural em que ele ocorre, e analisar a forma como as diferentes trajetórias se constituem perante as possibilidades socioculturais para a elaboração e a implementação de projetos específicos (VELHO, 1994).

Em um modelo proposto por Kleinman (1978;1980), acerca das diferentes interpretações sobre doenças e processos de tratamento, aponta-se para uma articulação sistêmica entre diferentes elementos ligados à saúde, como por exemplo, a experiência de sintomas, modelos específicos de conduta do doente, decisões concernentes ao tratamento, práticas terapêuticas e avaliação dos resultados.

Este autor considera que a maioria dos cuidados com a saúde contém três arenas sociais onde a enfermidade é vivenciada, são elas: profissional, folk e popular: 
$\checkmark$ A arena profissional: é formada pela medicina científica "ocidental" cosmopolítica, pelas profissões paramédicas ou pelos sistemas médicos tradicionais.

$\checkmark$ A arena folk: é composta pelos especialistas "não oficiais" da cura, como curandeiros, rezadeiros, e espiritualistas "não oficiais".

$\checkmark$ A arena popular: compreende o campo leigo, não especializado da sociedade, como a automedicação, conselhos de amigos, vizinhos, dentre outros.

É justamente nesta última arena que são resolvidasa maioria das questões ligadas à interpretação, ao tratamento e ao cuidado com a doença.

O Itinerário Terapêutico existe desde os primórdios da humanidade. Isto porque os indivíduos enfrentam as doenças em seu cotidiano, desenvolvendo várias estratégias no processo saúde-doença, e o ambiente em que vivem serve de cenário para o estudo dos itinerários.Assim,os tratamentos são construídos de forma individual e coletiva, correspondendo às necessidades para enfrentar os agravos encontrados pelos indivíduos (ROSA, 2007 apud LEITE; VASCONCELOS, 2006).

Há uma importante relação entre Itinerário Terapêutico e pobreza, onde a busca de cuidados terapêuticos descreve práticas individuais e socioculturais de saúde em relação aos caminhos percorridos, com a finalidade de encontrar solução para uma necessidade de saúde, que pode ser um sintoma físico ou psíquico (GERHARDT, 2006).

Conhecer e analisar o Itinerário Terapêutico, no intuito de entender como e em que momento os indivíduos procuram ajuda para solucionar suas demandas e agravamento da saúde, é cada vez mais frequente em estudos sobre o planejamento, organização e avaliação de serviços assistenciais de saúde. É buscar compreender a escolha de estratégias adequadas que garantam acesso aos usuários no momento certo, de forma contínua, possibilitando vínculo com a equipe de profissionais de saúde e, com isso, a adesão ao tratamento proposto (CABRAL et al., 2011).

O panorama atual da saúde no Brasil permite entender que, em geral, os profissionais de saúde não são preparados para estabelecer condutas ágeis, seguras e resolutivas à população. Através do estudo do Itinerário Terapêutico podem ser observadas limitações na resolubilidade dos agravos de saúde, e a insensibilidade com a população, que percorre longos percursos em busca de serviços e tratamentos.

Os conceitos e ideias relacionados à saúde e à doença, ainda se concentram no modelo biomédico, por isso, é necessário apropriar-se de um modelo orientado pela promoção da saúde, fortalecendo a autonomia dos sujeitos. Isso significa preparar os indivíduos para que 
sejam capazes de agir de forma individual e coletiva, considerando o contexto em que vivem. Contudo, é necessário que o profissional compreenda a saúde em suas diferentes dimensões, considerando as práticas integradoras, assim como as desigualdades sociais que limitam e/ou impedem o acesso aos serviços de saúde e à informação (SILVA et al., 2014).

A prática de saúde no Brasil é hegemonicamente hospitalocêntrica, com grande lacuna na atenção primária, evidenciando falhas no enfrentamento dos problemas básicos de saúde e nas linhas de cuidado. Por isso, é necessário implementar medidas de promoção à saúde e prevenção de agravos, buscando transformar o panorama atual dos serviços que são oferecidos.

A população precisa ter acesso a informações e intervenções pertinentes ao momento do processo saúde-doença, e assim, seja corresponsável pela prevenção, promoção e recuperação da sua própria saúde, com autonomia para enfrentar potenciais agravos em suas vidas cotidianas.

É relevante considerar também, que o livre acesso aos serviços, quando estes são eficientes, proporciona segurança e tranquilidade ao usuário e facilita o seu percurso em busca de cuidados. Nesse contexto, é fundamental a interação entre os profissionais, nas diversas áreas da saúde e nos diversos níveis de atenção, para que sejam resolutivos em sua assistência.

A revisão de literatura demonstra que estudos sobre Itinerário Terapêutico ainda são insuficientes, o que, se fosse de outra forma, qualificaria positivamente os serviços de saúde.

Na região de Santarém-PA é clara a insatisfação dos usuários que buscam atendimento para suas necessidades de saúde, assim como a fragilidade e a ineficiência do sistema de saúde ante tais necessidades. É comum deparar-se com usuários "perdidos”, sem orientações, e sem apoio para traçar itinerários que garantam melhor acesso e qualidade dos serviços.

A trajetória percorrida se dá entre os níveis de atenção em saúde, e depende da necessidade que o indivíduo apresenta, sendo por ela delimitada. O sistema de "regulação" dos serviços de saúde é responsável por intermediar o fluxo de serviços, e deveria direcionar as referências e contrarreferências nos três níveis de atenção à saúde, e nas intervenções realizadas (BELLATO et al., 2008).

Entre os obstáculos enfrentados pelos usuários na busca de atendimento e as fragilidades do Sistema Único de Saúde (SUS), em garantir serviços eficientes, ainda há outras dificuldades, comuns em algumas regiões do Brasil. Destaca-se aqui a situação na região do Oeste do Pará, onde a população enfrenta desafios no acesso aos serviços de saúde, devido à extensão territorial. 
Nesta região, os usuários são referenciados de cidades vizinhas, comunidades de várzea, planalto e distritos distantes, percorrendo longos caminhos, em transporte público, por estradas em estado precário, sem pavimentação adequada, ou de barco, pelos extensos rios da região, em viagens que muitas vezes duram horas ou mais do que um dia para chegar ao Município onde há serviços especializados.

Para compreender o caminho vivenciado por cada indivíduo, é necessário também compreender, que as formas de cuidado adotadas partem das relações do indivíduo com familiares, vizinhos, terapeutas populares, organizações religiosas, além do próprio serviço de saúde procurado (ROSA,2007 apudSCHOLZE; SILVA, 2005).

A experiência da doença se constitui em uma situação-problema que leva o indivíduo à reflexão sobre um processo até então desconhecido. Enfrentar a enfermidade remete a um conjunto de práticas, crenças e valores, em que a pessoa que apresenta um determinado agravo ou necessidade, junto aos seus familiares, vizinhos e terapeutas, cria, reproduz e transmite soluções, receitas, práticas e proposições. Este processo ocorre por meio de escolhas referentes ao universo sociocultural em que o indivíduo está inserido, pela situação presente, pelas experiências vividas, e por projetos de vida previamente elaborados por cada um (NABÃO; MARUYANA, 2006).

\subsection{VULNERABILIDADE: CONCEITO}

A partir do pressuposto de que no processo saúde-doença, nas diversas circunstâncias da vida, os indivíduos buscam um Itinerário Terapêutico específico para atendersuas necessidades, e que a acessibilidade aos serviços de saúde e o contexto socioeconômico de cada indivíduo, grupo social e população, influencia na qualidade da assistência, no tratamento, e na resolubilidade do agravo à saúde, a seguir apresentam-se alguns aspectos importantes a respeito do conceito de vulnerabilidade e itinerário terapêutico, com base em alguns autores.

A constituição da ciência epidemiológica configura-se, em pressupostos epistemológicos e procedimentos conceituais,descritana busca do conhecimento sobre a saúde-doença, e na forma como as populações estabeleceram seus modos de viver. Isto influenciou a construção de um conceito formal da epidemiologia de risco (AIRES et al., 2006).

Com o início da epidemia de AIDS, após os avanços do conhecimento sobre corpo e técnicas e tecnologias de cuidado à saúde e prevenção de agravos, emerge a necessidade de 
estabelecer associações probabilísticas, através do uso do instrumental epidemiológico, que apoiaria a identificação de fatores de risco relacionados a essa nova doença (AYRES et al., 2006).

Segundo os autores mencionados acima, a análise de vulnerabilidade, no contexto da AIDS, poderia ser estabelecida em três dimensões:

$\checkmark \quad$ Dimensão Individual: diz respeito ao modo de vida de cada indivíduo, que pode contribuir para sua exposição ao agente etiológico ou a proteger-se deste; está relacionada ao grau de informação sobre o agravo, e à incorporação desta em sua vida cotidiana.

$\checkmark \quad$ Dimensão Social:diz respeito ao acesso à informação, ao conteúdo e qualidade dessa informação, aos significados que as informações representam perante os valores e interesses das pessoas, assim como à possibilidade de colocá-las em prática.Também refere-se ao acesso aos meios de comunicação, à escolaridade, à disponibilidade de recursos materiais, ao poder de influenciar decisões políticas, à possibilidade de enfrentar barreiras culturais, dentre outros elementos.

$\checkmark \quad$ Dimensão programática: está relacionada à vida das pessoas em sociedade ea instituições sociais como, famílias, escolas, serviços de saúde, etc. A análise dessa dimensão requer avaliar como as instituições (de saúde, educação, bem-estar social, cultura) atuam, reproduzem ou aprofundam condições de vulnerabilidade. Refere-se a como os serviços de saúde, de educação, atuam, para oferecer à sociedade, percepção e superação em relação a um contexto desfavorável ao qual estão as vulnerabilidades. Assim, a elaboração de propostas de intervenção deve sempre ser realizada entre os sujeitos e os seus contextos sociais, estimulando a participação e a autonomia dos indivíduos, no diagnóstico, e na busca de caminhos que os ajudem a superar o desafio da vulnerabilidade.

De fato, a definição de vulnerabilidade apresenta uma multiplicidade significativa. Wisner, por exemplo, a define na perspectiva de indivíduos e populações expostos aos acidentes, apontando aspectos relevantes que neles incidem, como o nível socioeconômico, a ocupação, a nacionalidade, pois estes fatores repercutem no acesso à informação, aos serviços e à disponibilidade de recursos, que podem potencializar ou diminuir a vulnerabilidade (SÁNCHEZ; BERTOLOZZI, 2007).

No contexto da família, Gomes e Pereira (2005, p.362) ressaltam que a condição de vulnerabilidade está atrelada às políticas públicas: 
As políticas sociais muito pouco têm contribuído para amenizar as condições de vulnerabilidade da família pobre, no entanto, há de se fazer referência em termos de política pública que centrou seu foco na família. O PSF tem como unidade de atendimento a família em seu habitat e prevê ações que levem em conta a possibilidade de detectar no domicilio as necessidades de suporte e incrementar estratégias comunitárias no sentido de ampliar redes de apoio social. Com atenção contínua e ativa, desenvolve ações de promoção, proteção e recuperação da saúde dos indivíduos e da família de forma integral e contínua, objetivando com isso melhorar a qualidade de vida dos indivíduos.

Os autores abordam a importância de políticas, no enfrentamento das condições vulneráveis de famílias pobres, assim como o impacto que uma estratégia apropriada pode proporcionar no combate às desigualdades sociais. 


\section{JUSTIFICATIVA}

\section{JUSTIFICATIVA}

O escorpionismo é reconhecido como um problema de saúde públicaem alguns países em desenvolvimento devido à significativa incidência ou gravidade, particularmente entre crianças e idosos com morbidades (CHIPAUX; GOYFFON, 2008). A frequente limitação de conhecimento para o manejo apropriado e a dificuldade de gestão dos serviços de saúde (SS) em abordar os pacientes picados contribuem para a magnitude do agravo. A avaliação precoce da gravidade e o acompanhamento da evolução do quadro clínico, com a consequente instituição terapêutica adequada, são determinantes para um bom prognóstico.

A sintomatologia da vítima é determinada por muitos fatores que atuam simultaneamente, como a idade e peso do paciente, a espécie de escorpião causador do acidente, a quantidade de veneno inoculada, o tempo entre a picada e o atendimento realizado pelo profissional de saúde e a correta abordagem terapêutica. 
Nesse contexto, há necessidade de informar a população a respeito de condutas adequadas, e da necessidade de procurar imediatamente o serviço de saúde. É fundamental também, que o serviço de saúde tenha profissionais capacitados e estrutura adequada para estabelecer o tratamento sintomático e a soroterapia específica, caso haja indicação, evitando complicações severas e o óbito das vítimas.

No Município de Santarém-PA, na Amazônia, constituído de zona urbana e rural, com diversas comunidades que vivem em áreas de planalto e de várzea, o acidente escorpiônico é frequente. Nestas regiões há muita dificuldade de acesso aos serviços de saúde e, muitas vezes, limitações na formação de recursos humanos para atender a estes pacientes, conforme preconiza o Ministério da Saúde.

A população local, na maioria das vezes, desconhece as orientações corretas do manejo nos primeiros socorros à vítima de picada de escorpião, o que pode prejudicaro prognóstico, aumentando a frequência de complicações graves. Não é raro o uso de ervas ou medicamentos caseiros para o tratamento do acidente escorpiônico, o que também pode influenciar na evolução do quadro. Justifica-se, pois, este estudo, que tem a finalidade de contribuir para identificar os principais estrangulamentos que limitam o acesso dos pacientes aos serviços de saúde, em sua trajetória de busca pelo cuidado, além de contribuir para divulgar o conhecimento sobre ações de prevenção e de manejo imediato após o acidente. Neste sentido, o estudo foi conduzido a partir das seguintes questões norteadoras:

Quais são as dificuldades encontradas pelas vítimas de escorpionismo desde o momento da picada (ferroada) até o atendimento hospitalar? Os serviços de atendimento de Atenção Primária local atendem/participam do atendimento aos acidentes ocorridos nas comunidades? Há materiais de divulgação para informar a população quanto aos sintomas, primeiros socorros e tratamento do escorpionismo? Qual a percepção do usuário, em relação à necessidade de buscar tratamento para o escorpionismo? Como o paciente caracteriza esta experiência?

Nessa linha, realizou-se uma pesquisa acerca da trajetória percorrida da vítima de acidente por escorpião, avaliando características epidemiológicas e alguns aspectos do quadro clínico, assim como a análise do percurso realizado pela vítima na busca de cuidados e tratamento específico.

Este estudo é de grande relevância para a Enfermagem, uma vez que esta área reúne profissionais que atuam rotineiramente no enfrentamento do agravo, seja em UBSs ou em unidades de pronto atendimento (UPAs), incluindo serviços de emergência, estabelecendo o 
primeiro contato com as vítimas de picada de escorpião. Contudo, nem sempre possuem o devido preparo para conduzirem o cuidado de forma correta. 


\section{OBJETIVOS}

\section{OBJETIVOS}

\subsection{OBJETIVO GERAL:}

Analisar como se processa a ocorrência de acidentes escorpiônicos no Município de Santarém-PA.

\subsection{OBJETIVOS ESPECÍFICOS:}

$\checkmark$ Identificar características epidemiológicas de pessoas acometidas por acidente escorpiônico; 
$\checkmark$ Verificar como a população procede em relação ao manejo desse acidente;

$\checkmark$ Verificar como é o trajeto percorrido pelos pacientes até o estabelecimento do tratamento adequado;

$\checkmark$ Identificar o conhecimento da população para subsidiar um instrumento acerca da prevenção e do manejo adequado ao agravo escorpiônico. 


\section{MÉTODO}

\section{MÉTODO}

\subsection{DESENHO DO ESTUDO}

O estudo foi observacional, exploratório, prospectivo, descritivo e qualitativo. Os dados foram coletados por meio de dois questionários, sendo que o questionário (A) buscou caracterizar os sujeitos participantes, em termos socioeconômicos, demográficos e epidemiológicos, além das manifestações clínicas. O questionário (B) contém perguntas abertas e permitiu analisar o itinerário terapêutico, na busca de cuidado em decorrência do escorpionismo. 
Foram realizadas 19 entrevistas com o questionário (A), e apenas 18 com o questionário (B), pois uma paciente recebeu alta, não havendo tempo para a entrevista. As entrevistas foram gravadas e transcritas integralmente.

\subsection{PERÍODO DE COLETA DE DADOS}

A coleta de dados ocorreu de 28 de Outubro de 2016 a 27 de Fevereiro de 2017.

\subsection{CENÁRIO DO ESTUDO}

O estudo foi realizado no Pronto Socorro Municipal (PSM) que se localiza no Município de Santarém-PA, após a autorização da Secretaria Municipalde Saúde — SEMSA (ANEXO A)e do Hospital Municipal de Santarém - HMS (ANEXO B). O Município está situado na Amazônia, à margem direita do Rio Tapajós. O clima é predominantemente equatorial, quente e úmido. A base de sua economia é o comércio, a pesca, a agricultura, o artesanato e o turismo (IBGE, 2010).

Figura 6: Pronto Socorro Municipal de Santarém - PSM

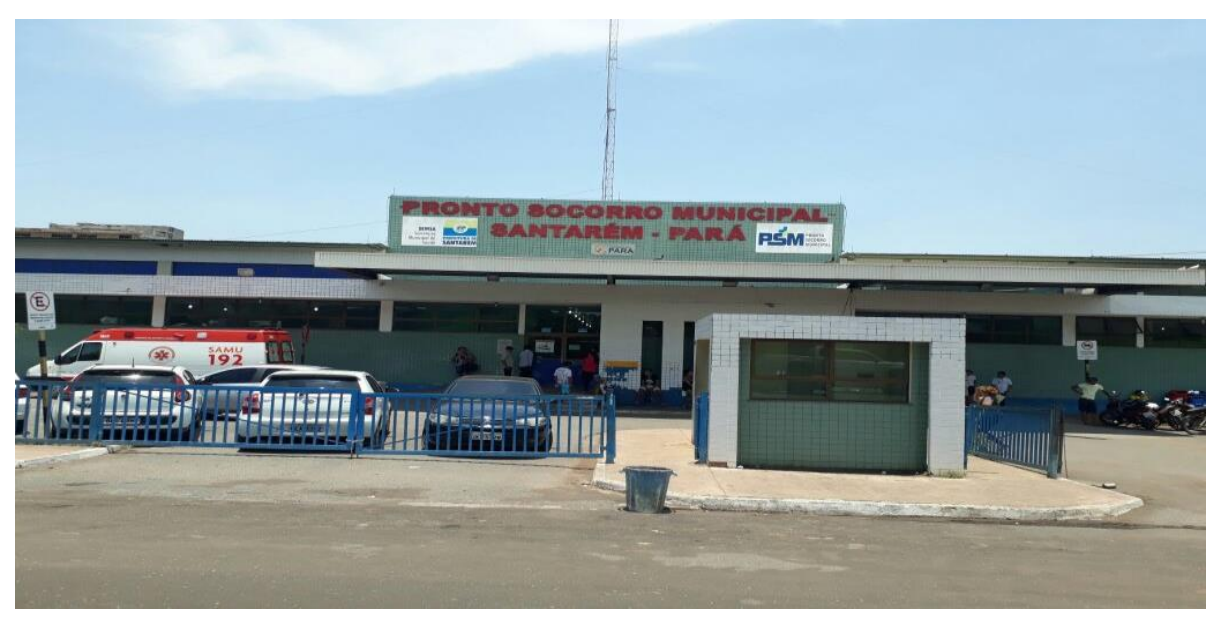


Fonte: Acervo fotográfico da pesquisadora (2017).

Figura 7: Estado do Pará

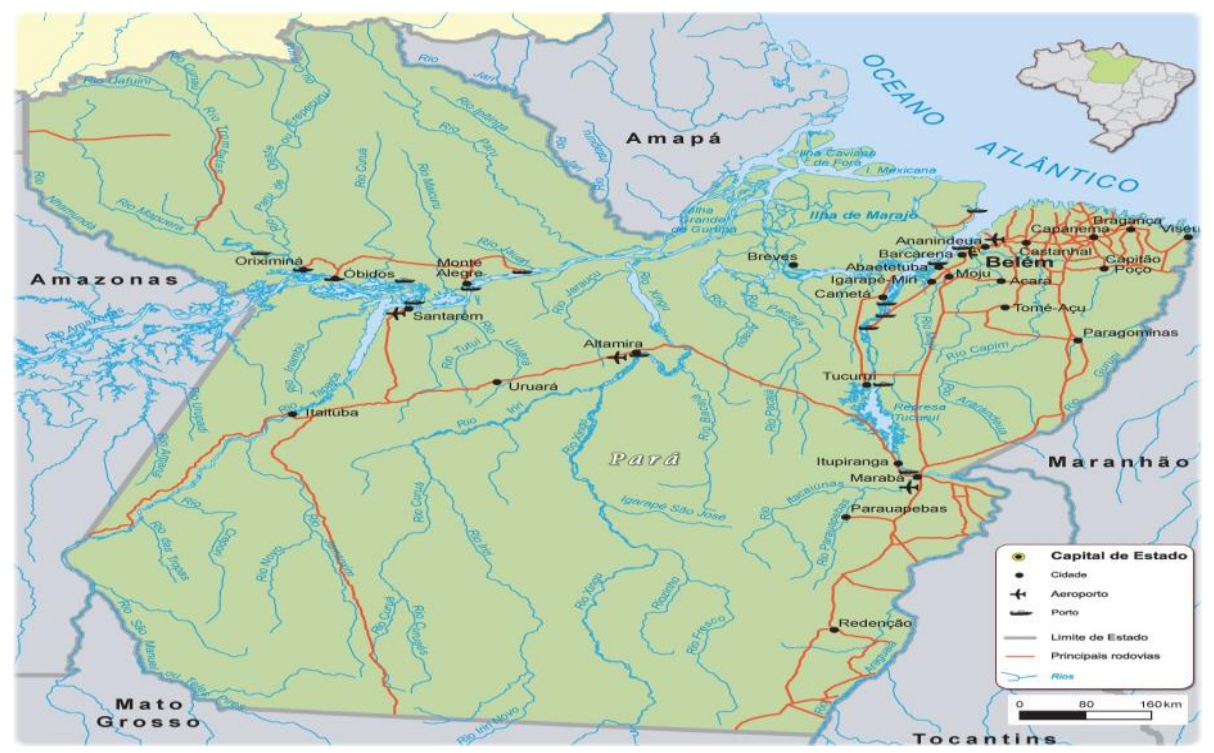

Fonte: Instituto Brasileiro de Geografia e Estatística (IBGE), 2016.

Os serviços de saúde do Município possuem como referência dois hospitais que atendem a demanda de toda a região do Baixo Amazonas: o Hospital Municipal de Santarém (HMS) e o Hospital Regional do Baixo Amazonas (HRBA).

O primeiro, HMS, é de competência municipal e oferece serviços de baixa e média complexidade; possui 130 leitos, nas especialidades de Clínica Médica, Cirúrgica, Obstétrica, Pediátrica, Infectologia e Unidade de Terapia Intensiva (UTI). Tem portas abertas para urgência e emergência, recebendo pacientes de toda a região do oeste do Pará com os mais diversos agravos, entre os quais, os acidentes por escorpião.

Os pacientes vítimas de escorpionismo são atendidos pelos médicos infectologistas do PSM e pelos médicos colaboradores do Núcleo de Medicina Tropical (NUMETROP). Além do suporte pelos residentes da Comissão de Residência Médica (COREME) e dos acadêmicos de medicina da Universidade do Estado do Pará (UEPA), que atuam na área de infectologia.

O hospital HRBA é um órgão estadual, administrado por uma Organização Social, a Pró-Saúde, que administra a unidade desde 2009. É hospital de grande porte, referência em média e alta complexidade, mas não atende urgência e emergência. Possui 128 leitos, distribuídos nas áreas de Clínica Médica, Cirúrgica, Pediátrica, Oncológica e Obstétrica, além de serviços ambulatoriais em diversas especialidades, exames laboratoriais, de imagem, hemodiálise, quimioterapia, radioterapia e captação de órgãos para transplante em outros estados do País. 
Ambos são hospitais de ensino e pesquisa, e oferecem campo de estágio para Residência Médica, Internato de Medicina e Estágios Supervisionados em diversas áreas da saúde. Têm convênio com a Universidade do Estado do Pará (UEPA), com Instituições de Ensino Superior (IES) particulares, e com a Comissão de Residência Médica (COREME) da UEPA-Santarém, que possui 13 programas de Residência Médica aprovados pela Comissão Nacional de Residência Médica (CNRM).

O Município conta também com uma Unidade de Pronto Atendimento (UPA), uma unidade do SAMU e 103 Unidades Básicas de Saúde - UBS que, juntas, prestam assistência na atenção primária, secundária e terciária à população do Município, de cidades vizinhas, de distritos e comunidades de planalto e várzea. Os serviços de saúde de competência do Município são administrados pela Secretaria Municipal de Saúde (SEMSA) e os de competência do Estado, pela Secretaria do Estado do Pará (SESPA).

A extensão do Estado do Pará é um ponto nevrálgico que repercute no acesso aos serviços de saúde. Assim, grande parte da população referida por cidades vizinhas ou por comunidades distantes percorrem longos caminhos em transporte público, por estradas em estado precário, sem pavimentação adequada, ou por barco, navegando através dos extensos rios da região, muitas vezes levando horas ou dias até chegar aos hospitais de referência.

O Município possui 2 barcos ABARÉ, que levam assistência básica à população ribeirinha e de floresta; 2 "ambulanchas", que realizam o transporte de usuários das comunidades para o Município, em casos de urgência e emergência. No entanto, não são suficientes para suprir as necessidades de saúde da população.

O percurso que um usuário necessita realizar, na busca por atendimento que proporcione resolutividade e que muitas vezes requer rapidez, por se tratar de quadros agudos com variada gravidade, constitui-se em um verdadeiro calvário, com desgaste físico e psicológico, resultando, não raro, na desistência do usuário em buscar o serviço necessitado.

\subsection{SUJEITOS DO ESTUDO}

Os sujeitos do estudo foram pacientes vítimas de acidente escorpiônico, atendidos no Pronto Socorro Municipal de Santarém (PSM).

Foram critérios de inclusão: todos os sujeitos atendidos no PSM, independentemente da gravidade do quadro clínico, sexo, idade e condições de alta. Foi critério de exclusão vítimas que apresentassem comprometimento cognitivo que impedisse responder às perguntas da entrevista. 
Em 2 casos as entrevistas foram realizadas com o responsável da criança que foi acometida pelo acidente.

Algumas entrevistas necessitaram de 2 ou 3 visitas ao PSM para conseguir realizar a gravação completa, pois na(s) visita(s) inicial(is) o paciente não se encontrava suficientemente restabelecido para responder a todas as perguntas. Muitos apresentaram manifestações sistêmicas, como dificuldade para falar, e esta condição exigiu, em algumas situações, a suspensão da entrevista, com retorno posterior para completar a coleta dos dados sobre a experiência do acidente.

Durante o período de coleta, alguns pacientes que apresentavam quadro definido como leve, evadiram-se do Pronto Socorro Municipal de Santarém em menos de 3 horas após serem admitidos e, por este motivo, não foram entrevistados.

\subsection{INSTRUMENTOS DE COLETA DE DADOS}

Foram dois os instrumentos para a coleta de dados, denominados de (A) e (B): Através do questionário (A) foram coletados dados socioeconômicos, clínicos e epidemiológicos, a partir do exame clínico diário e de informações relacionadas ao acidente, fornecidas pelo paciente ou acompanhante (APÊNDICE A).

O exame clínico foi realizado diariamente durante a visita do profissional médico que assumia o plantão, até a alta do paciente, de forma a acompanhar a evolução de seu quadro clínico.

O questionário (B) incluiu perguntas abertas com a finalidade de fazer emergir como se processou a trajetória percorrida pela vítima de escorpionismo (APÊNDICE B).

As perguntas abertas foram gravadas e transcritas posteriormente para a análise do conteúdo. Nestas, a pessoa que sofreu o acidente foi convidada a descrever o percurso desde o momento da picada pelo escorpião até a admissão no serviço hospitalar (PSM) para o atendimento adequado, conforme preconiza o Ministério da Saúde, e quais foram as maiores dificuldades nesse percurso.

\subsection{PROCEDIMENTOS NA COLETA DE DADOS}

A coleta de dados foi realizada durante a internação do paciente. 
O questionário (A) foi preenchido pela pesquisadora e pelos médicos infectologistas responsáveis em prestar assistência médica aos pacientes vítimas do escorpionismo, com competência para avaliar clinicamente a sintomatologia do agravo, os quais foram convidados a participar do estudo, como colaboradores.

O questionário (B) foi aplicado exclusivamente pela autora do estudo. Dois pacientes não necessitaram de internação e permaneceram apenas em observação, e foram entrevistados antes da sua alta.

Algumas entrevistas foram realizadas em local restrito para conservar a privacidade do participante, no entanto, algumas foram realizadas à beira do leito, pois o paciente apresentava dificuldade para deambular.

Nos casos em que o paciente apresentou envenenamento moderado ou grave, foi necessário aguardar sua melhora para realizar a entrevista.

Acordou-se com profissionais do PSM, Enfermeiras e Técnicos, que a autora seria avisada, por ocasião da admissão de paciente vítima de acidente escorpiônico no prontosocorro do HSM. Todos os profissionais colaboradores da coleta de dados foram previamente esclarecidos e orientados sobre o tema, objetivos e métodos do estudo, para que pudessem abordar adequadamente as vítimas do escorpionismo, respeitando o protocolo de atendimento por picada de escorpião, de forma a conduzirem a aplicação do questionário (A) com coerência, ética e responsabilidade.

Após a admissão de cada paciente no pronto-socorro era feito o primeiro contato com ele, acompanhante ou representante legal, para apresentar os objetivos do estudo, por meio do Termo de Consentimento Livre e Esclarecido - TCLE (APÊNDICE C)ou do Termo de Assentimento Livre e Esclarecido (APÊNDICE D).

Seguem as etapas da coleta de dados:

1. Orientação sobre a importância do estudo e leitura do TCLE ao paciente ou acompanhante familiar.

2. Avaliação clínica do paciente e preenchimento do questionário pelo colaborador médico e a autora do estudo (Questionário A).

3. Reavaliação clínica diária, durante a visita médica, até a alta hospitalar.

4. Coleta do relato do participante do estudo, por meio de entrevista gravada.

\subsection{ANÁLISE DOS DADOS}


Os dados descritivos foram armazenados em planilha do Excel 2010. Os dados qualitativos foram gravados, transcritos integralmente conservando a expressão oral dos sujeitos e analisados segundo técnica apropriada de análise de conteúdo, da qual emergiram 5 (cinco) temas:

* Situação em que ocorreu o acidente escorpiônico;

* Trajetória percorrida pelo paciente até o tratamento;

* Providências após a ocorrência do acidente ("a ferroada");

* Manifestações clínicas apresentadas pelas vítimas dos acidentes escorpiônicos;

* O que foi feito com o escorpião (lacrau).

\subsection{ASPECTOS ÉTICOS}

Todos os preceitos éticos foram contemplados, segundo as recomendações da Resolução 466/12 do Conselho Nacional de Saúde (CNS).

O projeto foi aprovado pelo Comitê de Ética em Pesquisa (CEP) da Escola de Enfermagem da USP, sob o número do parecer 1.780.899. 


\section{RESULTADOS E DISCUSSÃO}

\section{RESULTADOS E DISCUSSÃO}

Apresentam-se, inicialmente, os resultados relativos à caracterização dos sujeitos. Participaram do estudo 19 sujeitos, que foram vítimas de acidente escorpiônico. Conforme anteriormente mencionado, a análise qualitativa ocorreu somente para 18 pessoas, pois um participante obteve alta antes da possibilidade de realizar-se a entrevista. 


\subsection{CARACTERIZAÇÃO SOCIOECONÔMICA E DEMOGRÁFICA DOS SUJEITOS, SITUAÇÃO EM QUE OCORREU O ACIDENTE E MANIFESTAÇÕES LOCAIS E SISTÊMICAS}

O perfil sócio-demográfico dos sujeitos do estudo está caracterizado no Quadro 2. Dos 19 entrevistados, $14(73,7 \%)$ foram as próprias vítimas que prestaram depoimento após seu restabelecimento e $5(26,3 \%)$ foram os pais ou responsáveis das vítimas, por serem pacientes menores de idade, e em 2 casos, tanto as vítimas quanto o responsável relataram.

Conforme anteriormente mencionado, a coleta de dados foi iniciada em 01 de novembro de 2016 e finalizada em 27 de fevereiro de 2017. O mês de Janeiro foi o que apresentou maior número de acidentes, com 9 (47,3\%) vítimas, como demonstra o Quadro 1.

Os acidentes foram mais frequentes na região rural, com $13(68,5 \%)$ casos, o que se justifica porque a espécie Tityus obscurus, implicada nesta ocorrência, não está plenamente adaptada ao habitat urbano.

Quanto ao local do corpo em que ocorreu o acidente, verificou-se maior incidência no pé, em $11(57,8 \%)$ das vítimas. Não houve predominância em relação ao período do dia, tendo sido registrados acidentes tanto pela manhã: 5 (26,3\%), como à tarde: $7(36,8 \%)$, e à noite $6(31,5 \%)$.

Quanto ao início dos sintomas, 14 (73,7\%) sujeitos disseram que os mesmos surgiram em até 1 hora.

Em relação ao tempo de internação,para6(31,5\%) foi maior que 24 horas.

Uma característica relevante também foi o tempo desde o momento da picada até a chegada da pessoa ao hospital, que foi maior que $1 \mathrm{~h}$ em 15 (78,9\%) casos. A distância entre as comunidades ribeirinhas e de planalto à região urbana do município de Santarém, onde se encontra o Hospital Municipal de Santarém (HMS), único local que possui o tratamento específico para o escorpionismo, é um dos nós críticos que dificultam a assistência àpopulação, evidenciando a dificuldade na trajetória percorrida e no acesso aos serviços de saúde, o que se assemelha ao estudo de Pardal et al. (2003), no que se refere à demora da vítima para chegar ao serviço de saúde, pois esta região tem grande predomínio da área rural, e também por apresentar dificuldade em relação à disponibilidade de meios de transporte.

Dados do Sistema Nacional de Agravo e Notificação - SINAN, registraram, no ano de 2015, 102 casos de escorpionismo em Santarém-Pará; destes, o tempo entre a picada e a chegada da vítima ao serviço de saúde foi de 6-12 horas em 11 casos, 12-24 horas em 3 casos, e mais do que 24 horas em 1 caso. Nos demais casos o tempo variou entre 1 a 6 horas. 
A internação foi considerada necessária para 19 (100\%) das vítimas atendidas no PSM, e o quadro clínico foi caracterizado como moderado ou grave, tendo sido administrado tratamento específico, qual seja, o uso do soro antiescorpiônico. De fato, todos esses pacientes só apresentaram condições para participar da entrevista após seu restabelecimento. Entretanto, todos evoluíram para completa remissão do quadro apresentado.

Verificou-se também que $3(15,7 \%)$ das vítimas já haviam sido picadas por escorpiões previamente. Quando interrogados sobre qual era o nome do animal, 11 (57,8\%) disseram que o conhecem como Lacrau.

O escorpião de coloração negra foi o maior responsável pelos acidentes, pois 17 $(89,4 \%)$ dos sujeitos afirmaram ter sido este o causador do acidente. Trata-se, provavelmente, do Tytius obscurus, a principal espécie causadora dos acidentes escorpiônicos na região de Santarém e, muito possivelmente, em muitas regiões da Amazônia, devido à sua ampla distribuição nessa região (PARDAL et al., 2003).

Entretanto, $16(84,2 \%)$ dos sujeitos não trouxeram o animal para ser identificado, o que pode evidenciar a falta de informação sobre a importância da captura do animal para que seja feita a sua identificação no serviço de saúde.

Quadro 2. Perfil Sócio-demográfico dos sujeitos do estudo. Santarém-PA, 2017.

\begin{tabular}{|c|c|c|c|}
\hline Indicador & Variável & $\mathbf{N}^{\mathbf{0}}$ & $\mathbf{\%}$ \\
\hline Paciente entrevistado & Sim & 14 & 73,7 \\
\cline { 2 - 4 } & Não & 5 & 26,3 \\
\hline
\end{tabular}




\begin{tabular}{|c|c|c|c|}
\hline \multirow[t]{2}{*}{ Se não, quem? } & Pai & 1 & 20 \\
\hline & Mãe & 4 & 80 \\
\hline \multirow[t]{5}{*}{ Meses de ocorrência } & Outubro(2016) & 3 & 15,7 \\
\hline & Novembro(2016) & 4 & 21 \\
\hline & Dezembro(2016) & 1 & 5,3 \\
\hline & Janeiro(2017) & 9 & 47,3 \\
\hline & Fevereiro(2017) & 2 & 10,6 \\
\hline \multirow[t]{3}{*}{ Local do acidente } & Zona urbana & 3 & 15,7 \\
\hline & Zona rural & 13 & 68,5 \\
\hline & Sem dados & 3 & 15,7 \\
\hline \multirow[t]{5}{*}{ Local da picada } & Dedo da mão & 1 & 5,3 \\
\hline & Mão & 5 & 26,3 \\
\hline & Braço & 1 & 5,3 \\
\hline & Joelho & 1 & 5,3 \\
\hline & Pé & 11 & 57,8 \\
\hline \multirow[t]{4}{*}{ Horário da picada } & Manhã & 5 & 26,3 \\
\hline & Tarde & 7 & 36,8 \\
\hline & Noite & 6 & 31,5 \\
\hline & Sem dados & 1 & 5,3 \\
\hline \multirow[t]{3}{*}{ Início dos sintomas } & Imediato & 3 & 15,7 \\
\hline & Até 1hora & 14 & 73,7 \\
\hline & Sem dados & 2 & 10,6 \\
\hline
\end{tabular}




\begin{tabular}{|c|c|c|c|}
\hline Indicador & Variável & $\mathbf{N}^{\mathbf{o}}$ & $\begin{array}{c}\text { (continuação) } \\
\%\end{array}$ \\
\hline \multirow{3}{*}{$\begin{array}{c}\text { Tempo de chegada ao } \\
\text { hospital }\end{array}$} & $<1$ hora & 2 & 10,6 \\
\hline & $>1$ hora & 15 & 78,9 \\
\hline & Sem dados & 2 & 10,6 \\
\hline \multirow[t]{4}{*}{ Tempo de internação } & $<24$ horas & 1 & 5,3 \\
\hline & 24horas & 4 & 21 \\
\hline & $>24$ horas & 6 & 31,5 \\
\hline & Sem dados & 8 & 42,1 \\
\hline \multirow[t]{3}{*}{ Cor do animal } & Preto & 17 & 89,4 \\
\hline & Marron & 1 & 5,3 \\
\hline & Sem dados & 1 & 5,3 \\
\hline \multirow[t]{4}{*}{ Nome do animal } & Escorpião & 5 & 26,3 \\
\hline & Lacrau & 11 & 57,8 \\
\hline & Lacráia & 1 & 5,3 \\
\hline & Sem dados & 2 & 10,6 \\
\hline \multirow[t]{2}{*}{ Trouxe o animal } & Sim & 3 & 15,7 \\
\hline & Não & 16 & 84,2 \\
\hline \multirow[t]{2}{*}{ Acidente anterior } & Sim & 3 & 15,7 \\
\hline & Não & 16 & 84,2 \\
\hline
\end{tabular}

Fonte: Questionário de Pesquisa (Autora). 
No Quadro 3, observa-se que grande parte dos sujeitos entrevistados foram do sexo masculino, $14(73,7 \%)$. Quanto à faixa etária, 5 (26,3\%) tinham idade entre 5-10 anos, e 2 $(10,6 \%)$ entre 11-20 anos, os demais eram adultos ente 21 e 60 anos.

No indicador estado civil, verifica-se que $10(52,6 \%)$ dos sujeitos são casados. No que se refere à orientação religiosa, $12(63,2 \%)$ eram católicos.

Quanto à ocupação, $8(42,1 \%)$ eram agricultores e 5 (26,3\%) estudantes. Em relação ao tempo de estudo, mesmo levando em consideração os sujeitos menores de idade, alguns dos sujeitos adultos possuem baixa escolaridade, sendo o maior número de anos de estudo entre 8 e 10 anos, em 7 (36,8\%) dos entrevistados.

No que se refere ao local de moradia dos sujeitos incluídos no presente estudo, em sua maioria: $13(68,5 \%)$ residiam na zona rural, correspondendo ao local de ocorrência do acidente, o que se pode depreender que vivem e trabalham no campo. Residiam em casa de madeira $8(42,1 \%)$. A maioria, 18 (94,7\%), moravam em casa própria, com os familiares.

Em relação ao número de horas de trabalho por dia, a maioria, 11 (57,9\%), trabalhavam de 8 a 12 horas. Quanto ao meio de transporte mais utilizado para se locomover, $9(47,3 \%)$ dos sujeitos responderam ser o ônibus.

No que se refere aos recursos financeiros, os sujeitos consideramo que ganham, respectivamente, suficiente para: morar, 15 (78,9\%); para comer, $17(89,4 \%)$; para o transporte, 9 (47,3\%); para o laser, $7(36,8 \%)$, e para vestir-se $10(32,6 \%)$.

Quadro 3. Perfil de condições de vida e trabalho dos sujeitos do estudo. Santarém-PA, 2017.

\begin{tabular}{|c|c|c|c|}
\hline Indicador & Variável & $\mathbf{N}^{\mathbf{0}}$ & $\%$ \\
\hline \multirow{2}{*}{ Sexo } & Feminino & 5 & 26,3 \\
\cline { 2 - 4 } & Masculino & 14 & 73,7 \\
\hline Faixa etária & $5-10$ & 5 & 26,3 \\
\hline
\end{tabular}




\begin{tabular}{|c|c|c|c|}
\hline \multirow[t]{4}{*}{ (anos) } & $11-20$ & 2 & 10,6 \\
\hline & $21-30$ & 5 & 26,3 \\
\hline & $41-50$ & 4 & 21 \\
\hline & $51-60$ & 3 & 15,8 \\
\hline \multirow[t]{3}{*}{ Estado civil } & Casado & 10 & 52,6 \\
\hline & Solteiro & 7 & 36,8 \\
\hline & Divorciado & 2 & 10,6 \\
\hline \multirow{2}{*}{$\begin{array}{c}\text { Orientação } \\
\text { religiosa }\end{array}$} & Católico(a) & 12 & 63,2 \\
\hline & Evangélico(a) & 7 & 36,8 \\
\hline \multirow[t]{5}{*}{ Ocupação } & Funcionário público(a) & 2 & 10,6 \\
\hline & Agricultor(a) & 8 & 42,1 \\
\hline & Esudante & 5 & 26,3 \\
\hline & Autônomo & 3 & 15,7 \\
\hline & Sem dados & 1 & 5,3 \\
\hline Indicador & Variável & $\mathbf{N}^{\mathbf{o}}$ & $\begin{array}{c}\text { (continuação) } \\
\%\end{array}$ \\
\hline \multirow{4}{*}{$\begin{array}{c}\text { Tempo de } \\
\text { estudo(anos) }\end{array}$} & $1-3$ & 2 & 10,6 \\
\hline & $4-7$ & 8 & 42,1 \\
\hline & $8-10$ & 7 & 36,8 \\
\hline & Sem dados & 2 & 10,6 \\
\hline \multirow[t]{2}{*}{ Reside em: } & Zona Urbana & 6 & 31,5 \\
\hline & Zona Rural & 13 & 68,5 \\
\hline
\end{tabular}




\begin{tabular}{|c|c|c|c|}
\hline \multirow[t]{4}{*}{ Tipo de moradia } & Madeira & 8 & 42,1 \\
\hline & Alvenaria & 5 & 26,3 \\
\hline & Mista & 1 & 5,3 \\
\hline & Sem dados & 5 & 26,3 \\
\hline \multirow{2}{*}{$\begin{array}{l}\text { Situação da } \\
\text { moradia }\end{array}$} & Própria & 18 & 94,7 \\
\hline & Sem dados & 1 & 5,3 \\
\hline \multirow{5}{*}{$\begin{array}{l}\text { Número de } \\
\text { pessoas que } \\
\text { moram na casa }\end{array}$} & $1-2$ & 4 & 21 \\
\hline & $3-4$ & 8 & 42,1 \\
\hline & $5-6$ & 5 & 26,3 \\
\hline & $>7$ & 1 & 5,3 \\
\hline & Sem dados & 1 & 5,3 \\
\hline \multirow[t]{3}{*}{ Coleta de lixo } & Sim & 4 & 21,1 \\
\hline & Não & 0 & 0 \\
\hline & Sem dados & 15 & 78,9 \\
\hline \multirow{5}{*}{$\begin{array}{l}\text { Meio de } \\
\text { transporte } \\
\text { utilizado }\end{array}$} & Ônibus & 9 & 47,3 \\
\hline & Motocicleta & 6 & 31,5 \\
\hline & Bicicleta & 1 & 5,3 \\
\hline & Ônibus/carro & 1 & 5,3 \\
\hline & Sem dados & 2 & 10,6 \\
\hline
\end{tabular}

\begin{tabular}{|c|c|c|c|}
\hline & & & (continuação) \\
Indicador & Variável & $\mathbf{N}^{\mathbf{0}}$ & $\%$ \\
\hline
\end{tabular}




\begin{tabular}{|c|c|c|c|}
\hline \multirow{4}{*}{$\begin{array}{c}\text { Serviço público } \\
\text { de saúde } \\
\text { utilizado }\end{array}$} & UBS & 15 & 78,8 \\
\hline & Hospital & 1 & 5,3 \\
\hline & UPA & 1 & 5,3 \\
\hline & Sem dados & 2 & 10,6 \\
\hline \multirow{6}{*}{$\begin{array}{l}\text { Recursos } \\
\text { Financeiros }\end{array}$} & Suficiente para morar & 15 & 78,8 \\
\hline & Suficiente para comer & 17 & 89,4 \\
\hline & $\begin{array}{l}\text { Suficiente para o } \\
\text { transporte }\end{array}$ & 9 & 47,3 \\
\hline & Suficiente para o lazer & 7 & 36,8 \\
\hline & Suficiente para vestir & 10 & 52,6 \\
\hline & Insuficiente para morar & 2 & 10,6 \\
\hline \multirow{5}{*}{$\begin{array}{c}\text { Recursos } \\
\text { Financeiros }\end{array}$} & Insuficiente para comer & 0 & 0 \\
\hline & $\begin{array}{c}\text { Insuficiente para o } \\
\text { transporte }\end{array}$ & 4 & 21 \\
\hline & Insuficiente para o lazer & 6 & 31,5 \\
\hline & Insuficiente para vestir & 4 & 21 \\
\hline & Sem dados & 2 & 10,6 \\
\hline
\end{tabular}

Fonte: Questionário de Pesquisa (Autora).

No Quadro 4 podem ser verificadas as características das manifestações locais causadaspelo envenenamento escorpiônico. A dor foi manifestada em 18 (94,7\%) dos sujeitos, seguido do edema em 11 (57,8\%), do eritema em 7 (36\%), do calor em $11(57,8 \%)$ e da piloereção em $1(5,3 \%)$ dos entrevistados.

A parestesia foi manifestada pela totalidade dos pacientes: 19 (100\%), seguida da sudorese em $8(42,1 \%)$ e da dor proximal em $12(63,1 \%)$

Quadro 4. Distribuição dos sujeitos do estudo segundo manifestações clínicasmencionadas. Santarém-PA, 2017. 


\begin{tabular}{|c|c|c|c|}
\hline Indicador & Variável & $\mathbf{N}^{\mathbf{o}}$ & $\%$ \\
\hline \multirow[t]{2}{*}{ Dor } & Sim & 18 & 94,7 \\
\hline & Não & 1 & 5,3 \\
\hline \multirow[t]{2}{*}{ Edema } & Sim & 11 & 57,8 \\
\hline & Não & 8 & 42,1 \\
\hline \multirow[t]{2}{*}{ Eritema } & Sim & 7 & 36,8 \\
\hline & Não & 12 & 63,1 \\
\hline \multirow[t]{2}{*}{ Calor } & Sim & 11 & 57,8 \\
\hline & Não & 8 & 42,1 \\
\hline \multirow[t]{3}{*}{ Piloereção } & Sim & 1 & 5,3 \\
\hline & Não & 9 & 47,3 \\
\hline & Sem dados & 9 & 47,3 \\
\hline \multirow[t]{2}{*}{ Parestesia } & Sim & 19 & 100 \\
\hline & Não & 0 & 0 \\
\hline \multirow[t]{3}{*}{ Sudorese } & Sim & 8 & 42,1 \\
\hline & Não & 9 & 47,3 \\
\hline & Sem dados & 2 & 10,6 \\
\hline \multirow[t]{2}{*}{ Dor proximal } & Sim & 12 & 63,1 \\
\hline & Não & 7 & 36,8 \\
\hline
\end{tabular}

Fonte: Questionário de Pesquisa (Autora).

Por meio do Quadro 5 pode se verificar que as manifestações sistêmicas mais frequentes nos sujeitos foram: tremor $15(78,9 \%)$, prostração $12(63,1 \%)$, astenia $9(47,3 \%)$, hipertermia $1(5,3 \%)$, taquicardia $8(42,1)$, hipertensão $8(42,1 \%)$, sudorese $11(57,8 \%)$, 
náusea $5(26,3 \%)$, vômitos $2(10,6 \%)$, sialorréia 10 (52,6\%), eupnéia $13(68,5 \%)$, cianose 2 $(10,6 \%)$.

Os sintomas de bradicardia, hipotensão, diarréia e priapismo não foram manifestados nos sujeitos desta pesquisa.

Cupo et al. (2009) também apresentam resultados semelhantes, apontando que pacientes com quadro moderado apresentaram, além das manifestações locais, algumas manifestações sistêmicas como náuseas, sudorese, taquicardia, taquipnéia, hipertensão arterial e agitação.

Quadro 5. Distribuição dos sujeitos do estudo segundo manifestações sistêmicas. Santarém-PA, 2017.

\begin{tabular}{|c|c|c|c|}
\hline Indicador & Variável & $\mathbf{N}^{\mathbf{o}}$ & $\%$ \\
\hline \multirow[t]{2}{*}{ Tremores } & Sim & 15 & 78,9 \\
\hline & Não & 4 & 21 \\
\hline \multirow[t]{3}{*}{ Prostração } & Sim & 12 & 63,1 \\
\hline & Não & 6 & 31,5 \\
\hline & Sem Dados & 1 & 5,3 \\
\hline \multirow[t]{3}{*}{ Astenia } & Sim & 9 & 47,3 \\
\hline & Não & 9 & 47,3 \\
\hline & Sem Dados & 1 & 5,3 \\
\hline \multirow[t]{3}{*}{ Hipertermia } & Sim & 1 & 5,3 \\
\hline & Não & 17 & 89,4 \\
\hline & Sem Dados & 1 & 5,3 \\
\hline \multirow[t]{3}{*}{ Taquicardia } & Sim & 8 & 42,1 \\
\hline & Não & 10 & 52,6 \\
\hline & Sem Dados & 1 & 5,3 \\
\hline
\end{tabular}




\begin{tabular}{|c|c|c|c|}
\hline Bradicardia & Sim & 0 & 0 \\
\cline { 2 - 4 } & Não & 18 & 94,7 \\
\cline { 2 - 4 } & Sem Dados & 1 & 5,3 \\
\hline Hipertensão & Sim & 8 & 42,1 \\
\cline { 2 - 4 } & Não & 10 & 52,6 \\
\cline { 2 - 4 } & Sem Dados & 1 & 5,3 \\
\hline
\end{tabular}

\begin{tabular}{|c|c|c|c|}
\hline Indicador & Variável & $\mathbf{N}^{\mathbf{o}}$ & $\begin{array}{c}\text { (continuação) } \\
\%\end{array}$ \\
\hline \multirow[t]{3}{*}{ Hipotensão } & Sim & 0 & 0 \\
\hline & Não & 18 & 94,7 \\
\hline & Sem dados & 1 & 5,3 \\
\hline \multirow[t]{2}{*}{ Sudorese } & Sim & 11 & 57,8 \\
\hline & Não & 8 & 42,1 \\
\hline \multirow[t]{2}{*}{ Náuseas } & Sim & 5 & 26,3 \\
\hline & Não & 14 & 73,7 \\
\hline \multirow[t]{2}{*}{ Vômitos } & Sim & 2 & 10,6 \\
\hline & Não & 17 & 89,4 \\
\hline \multirow[t]{3}{*}{ Sialorréia } & Sim & 10 & 52,6 \\
\hline & Não & 8 & 42,1 \\
\hline & Sem dados & 1 & 5,3 \\
\hline Diarréia & Sim & 0 & 0 \\
\hline
\end{tabular}




\begin{tabular}{|c|c|c|c|}
\hline & Não & 15 & 78,9 \\
\hline & Sem dados & 4 & 21 \\
\hline \multirow[t]{3}{*}{ Priaprismo } & Sim & 0 & 0 \\
\hline & Não & 11 & 57,8 \\
\hline & Sem dados & 8 & 42,1 \\
\hline \multirow[t]{3}{*}{ Eupnéia } & Sim & 13 & 68,5 \\
\hline & Não & 2 & 10,6 \\
\hline & Sem dados & 4 & 21 \\
\hline \multirow[t]{3}{*}{ Cianose } & Sim & 2 & 10,6 \\
\hline & Não & 9 & 47,3 \\
\hline & Sem dados & 8 & 42,1 \\
\hline
\end{tabular}

Fonte: Questionário de Pesquisa (Autora).

O Quadro 6 permite verificar outras manifestações sistêmicas que complementam a caracterização destes dados observados nos sujeitos. A dor foi manifestada por $17(89,4 \%)$ com início entre 0 a 15 minutos em $12(63,1 \%)$ dos sujeitos.

Em relação à sensação de choque, manifestou-se na maioria, 18 (94,7\%), com início entre 0 a 15 minutos em 7 (36,8\%) dos entrevistados. Para os demais surgiu em menos do que uma 1 hora.

Quanto à ataxia da marcha, manifestou-se em 17 (89,4\%), com início entre 0 a 15 minutos em 6 (31,5\%), seguido da dificuldade da fala em 14 (73,7\%) dos entrevistados, com início entre 0 a 15 minutos em 3 (15,7\%). Torrez et al. (2015) e Pardal etal. (2003) também observaram tais manifestações com frequência variável.

As manifestações sistêmicas apresentadas no Quadro 6 diferem dos acidentes graves observados por Cupo et al. (2015). No estudo destes autores há manifestações locais e algumas manifestaçõessistêmicas semelhantes (mas com menor frequência) como tremores e espasmos musculares, mas não apresentam manifestações compatíveis com disfunção cerebelar aguda, frequentemente descritas nos acidentes na região de Santarém. 
Cupo et al. (2015) enfatizam também a possível evolução para edema agudo de pulmão, insuficiência cardíaca e choque circulatório, que são as principais causas de óbito nos acidentes por escorpião no Brasil e na maior parte das regiões do mundo, mas que não ocorreram nos pacientes que compuseram a amostra do presente estudo.

As manifestações clínicas predominantemente neurológicas encontradas na região de Santarém, são diferentes das encontradas em outras regiões do Brasil (PARDAL et al., 2003; TORREZ et al. 2015).

Quadro 6. Distribuição dos sujeitos do estudo segundo manifestações sistêmicas. Santarém-PA, 2017.

\begin{tabular}{|c|c|c|c|}
\hline \multirow{2}{*}{ Indicador } & Variável & $\mathbf{N}^{\mathbf{0}}$ & $\mathbf{\%}$ \\
\hline \multirow{2}{*}{ Dor } & Sim & 17 & 89,4 \\
\cline { 2 - 4 } & Não & 2 & 10,6 \\
\hline \multirow{2}{*}{ Score } & $0-2$ Leve & 3 & 15,7 \\
\cline { 2 - 4 } & $3-7$ Moderada & 6 & 31,5 \\
\cline { 2 - 4 } & $8-10$ Intensa & 10 & 52,6 \\
\hline \multirow{2}{*}{$\begin{array}{c}\text { Início da Dor } \\
\text { (Tempo em } \\
\text { Minutos) }\end{array}$} & $0-15$ & 12 & 63,1 \\
\cline { 2 - 4 } & $16-30$ & 6 & 31,5 \\
\cline { 2 - 4 } & Sem dados & 1 & 5,3 \\
\hline
\end{tabular}

\begin{tabular}{|c|c|c|c|}
\hline \multirow{2}{*}{ Indicador } & Variável & $\mathbf{N}^{\mathbf{0}}$ & $\begin{array}{c}\text { (continuação) } \\
\text { \% }\end{array}$ \\
\hline \multirow{2}{*}{$\begin{array}{c}\text { Sensação de choque } \\
\text { elétrico }\end{array}$} & Sim & 18 & 94,7 \\
\cline { 2 - 4 } & Não & 1 & 5,3 \\
\hline \multirow{2}{*}{$\begin{array}{c}\text { Início da sensação de } \\
\text { choque elétrico }\end{array}$} & $0-15$ & 7 & 36,8 \\
\cline { 2 - 4 } & $16-30$ & 3 & 15,7 \\
\cline { 2 - 4 } & $>30$ & 2 & 10,6 \\
\cline { 2 - 4 } & Sem dados & 1 & 31,5 \\
\hline Ataxia de Marcha & Sim & 17 & 5,3 \\
\cline { 2 - 4 } & Não & 2 & 89,4 \\
\hline
\end{tabular}




\begin{tabular}{|c|c|c|c|}
\hline \multirow{4}{*}{$\begin{array}{c}\text { Início da Ataxia de Marcha } \\
\text { (minutos) }\end{array}$} & $0-15$ & 6 & 31,5 \\
\cline { 2 - 4 } & $16-30$ & 4 & 21 \\
\cline { 2 - 4 } & $>30$ & 1 & 5,3 \\
\cline { 2 - 4 } & $>1$ hora & 5 & 26,3 \\
\cline { 2 - 4 } & Sem dados & 3 & 15,7 \\
\hline \multirow{4}{*}{$\begin{array}{c}\text { Dificuldade para falar } \\
\text { Início da dificuldade para } \\
\text { falar(minutos) }\end{array}$} & Sim & 14 & 73,7 \\
\cline { 2 - 4 } & Não & 5 & 26,3 \\
\cline { 2 - 4 } & $16-30$ & 3 & 15,7 \\
\cline { 2 - 4 } & $>30$ & 3 & 15,7 \\
\cline { 2 - 4 } & $>1$ lhora & 5 & 5,3 \\
\cline { 2 - 4 } & Sem dados & 7 & 36,8 \\
\hline
\end{tabular}

Fonte: Questionário de Pesquisa (Autora).

\subsection{OSDEPOIMENTOSDOS SUJEITOS DO ESTUDO}

Conforme anteriormente dito, foram entrevistados 18 pacientes. Os depoimentos foram submetidos à análise de conteúdo, que possibilitou a emergência de cinco temas:

Situação em que ocorreu o acidente escorpiônico;

* Trajetória percorrida pelo paciente até o tratamento;

Providências após a ocorrência do acidente(“a ferroada”);

Manifestações clínicas apresentadas pelas vítimas dos acidentes escorpiônicos; 
O que foi feito com o escorpião (lacrau).

\section{Tema 1: Situação em que ocorreu o acidente escorpiônico.}

As narrativas sobre as situações em que ocorreram os acidentes demonstram que as vítimas encontravam-se em situações que favoreciam a sua ocorrência. Dos 18 sujeitos entrevistados, 14 relataram que, no momento do acidente, estavam realizando atividades manuais como: fazer uma trilha (um caminho), carregar toras de madeira, "trabalhando" com a terra (plantando arroz, abóbora, capinando). Quatro encontravam-se no interior do domicílio em atividades domésticas e uma criança estava brincando no terreiro, como demonstram os fragmentos $5,11,13,17,18$.

Uma característica importante, é que a maioria dos acidentes ocorreu em região de planalto ou floresta, o que evidencia maior risco de acidente nessas áreas, como demonstram os relatos.

"Ele foi no mato, ele fez um ramal de tarde, então foi até o mato vê se conseguia pegar uma caça, chegando lá, ele agarrou levou o pé ai ele sentiu uma ferrada". Sujeito 1.

“Eu tava andando no sitio, pisei no lado do escorpião e ele ferrou”. Sujeito 2.

\footnotetext{
"Sim. Eu tava no mato é.... partindo estaque e... num certo momento nós fomo tomba uma tora de madeira e quando eu meti a mão no pau que a gente chama de nerva, pra ajudar a rolar a madeira eu peguei em cima do escorpião e ele me picou. " Sujeito 3.
}

Os escorpiões também são encontrados, com relativa frequência, no interior dos domicílios, com uma tendência crescente a se adaptarem ao ambiente urbano, devido à facilidade de encontrarem alimento, como baratas (BRASIL, 2009).

“....ela tava... jantando e foi pra televisão, ai normalmente ela vai pra televisão e encosta o braço na parede! Ele pegou por cima da cortina né? Mas pegou de cheio, quando ele picou a garota o meu filho falou: pai! A ! O inseto pegou ela aqui pai! vamo vê onde Foi? Ai ele correu abriu a cortina... era o escorpião!’ Sujeito 13.

O relato dos sujeitos, sobre a situação em que se encontravam no momento do acidente, proporciona uma noção sobre o modo de vida dessa população, suas práticas diárias, o trabalho que realizam. 


\begin{abstract}
“Eu tava na roça! Sai pra plantar umas abóboras lá! dai passei mais pra frente, tava roçando de baixo dos pés de manga lá, nos arvoredo quando eu tava roçando com o facão, tava de chinelo num tinha ido de bota, coisa que eu não saio sem bota de jeito nenhum. Ai eu falei eu num vou com essa bota ta tudo limpo, tava tudo limpo lá debaixo dela! É folha né! Têm aqueles matinho lá, ai eu comecei a cortar, quando eu vi a ferroada no pé, que eu olhei ele tava grudado no pé, eu vi o escorpião preto grudado no pé, ai eu peguei só chacoalhei o pé e ele saiu também..." Sujeito 12.
\end{abstract}

\begin{abstract}
"Foi assim, a gente tava lá no forno né? a gente ia seca ele lá, a gente tem um forno de carvão lá, que a gente faz, aí ontem a fomos lá, eu abri lá pra limpa todinho que a gente ia ajeitar, ai eu fui tira... eu fui tira um, eu fui tira uma bacia assim de pneu, ai quando eu afastei assim eu não prestei atenção, só fiz afastar assim mesmo, ai na hora que eu fui pega alguns materiais que tinha assim pra limpa, ai só que eu já senti uma ferrada assim bem forte mesmo, ai eu olhei assim pro chão ai eu vi só um bichinho assim tipo uma centopéia mas eu falei será que foi isso? Ai o meu amigo disse olha um lacrau, escorpião... "Sujeito 6.
\end{abstract}

"Tava capinando, capinando....uma tarefa lá pra plantar arroz, ai na hora que eu cortei assim a moita ela saiu de dentro, ai ferrou bem no meu pé. Eu tinha tirado o "calçado também, tava cheio de barro ai eu tirei, ai na hora que eu cortei o mato...eu já ia embora ai ela ferrou...” Sujeito 15.

"O meu amigo tava trabalhando, e... ele mandou eu carregar estaca, e...e...ele mandou eu carregar estaca e..eu carreguei uma estaca, butei no ombro eu senti a picada aqui, na hora que senti a picada eu cai, num conseguia levanta não, num consegui, um amigo carregô...." Sujeito 14.

De acordo com os fragmentos 6,15, atividades que integram o cotidiano da zona rural, como capinar, plantar, ou manusear uma carvoaria, propiciam a ocorrência de diversos acidentes, neste caso, o acidente por escorpião.

As narrativas deste eixo temático expressam situações de vulnerabilidade individual e social, conforme ensina Ayres (2006):A dimensão individual refere-se ao modo de vida, e de como pode contribuir para a exposição a um agravo à saúde ou a proteger-se deste. A dimensão individual também está relacionada ao grau de informação e à sua incorporação no diaadia.

A dimensão social diz respeito ao acesso às informações e como as pessoas as interpretam e incorporam no cotidiano. Todo esse processo não depende unicamente do indivíduo, mas do grau de escolaridade, do acesso a recursos materiais, dentre outros aspectos.

As condições de saúde de um indivíduo são estabelecidas a partir de uma série de fatores, e não se restringem à atitude comportamental, mas de todo um contexto sociopolíticocultural e econômico e de serviços disponíveis que irão propiciar ou não os riscos para que ocorra ou não um determinado agravo à sua saúde (NICHIATA et al., 2008). 
A população ribeirinha e de florestageralmente tem pouco acesso a informações pertinentes à prevenção de acidentes por animais peçonhentos, sobre sua gravidade e os primeiros cuidados após o acidente.

A situação em que ocorreu o acidente também pode ser analisada a partir dos Determinantes Sociais de Saúde (DSS),segundo o modelo proposto por Dahlgren e Whitehead (2007).

O indivíduo está na base, na primeira categoria, que inclui idade, sexo e fatores genéticos. A segunda categoria refere-se aos estilos de vida dos indivíduos, seguida da terceira, que inclui as redes comunitárias e de apoio que possibilitam uma rede de solidariedade aos grupos mais desfavorecidos da sociedade. A quarta categoria diz respeito às condições de vida e de trabalho, e na quinta e última categoria estão os macrodeterminantes, que são as condições socioeconômicas, culturais e ambientais, como exemplifica a figura 8.

Figura 8: Modelo das categorias dos Determinantes Sociais da Saúde.

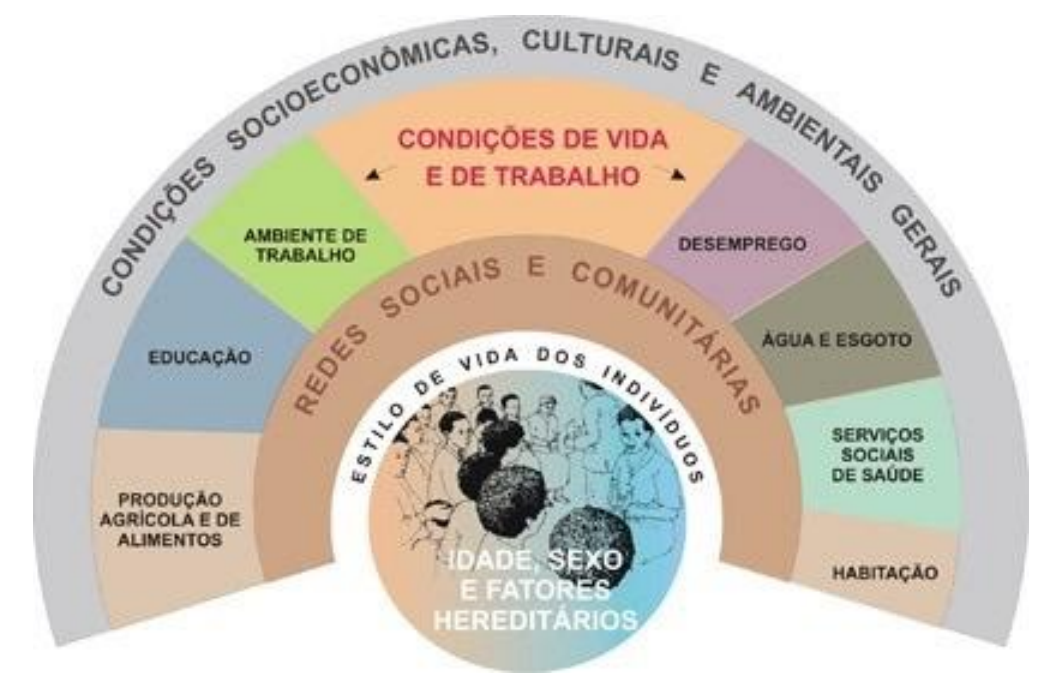

Fonte:Dahlgren e Whitehead, 2007. 
Aquarta categoria é evidenciada no relato dos sujeitos, e envolve a condição em que ocorreu o acidente. Conforme apresentado anteriormente, no perfil de ocupação dos sujeitos do estudo, a maioria eram trabalhadores braçais, com pouca segurança em seu trabalho, o que propicia condições que favorecem a ocorrência do acidente, como mostra o fragmento 9.

\footnotetext{
"É..eu fui é..levantá uma estaca, tava carregando estaca e quando eu fui vê o escorpião, tava na madeira... "Sujeito 9.
}

\title{
Tema 2: Trajetória percorrida pelo paciente até o tratamento.
}

Os relatos das trajetórias foram expressos através de concepções singulares sobre o cuidado à saúde, experiências de vida, da cultura local, e do adoecimento, peculiares ao homem do campo como demonstra os relatos 3 e 4 .

\begin{abstract}
“...Ai eu ainda fiquei por lá...e ai quando eu comecei a sentir os sintomas ai a gente veio embora pra casa....ai nós resolvemos vim embora, ai chegando em casa o papai foi até o posto de saúde da comunidade do Palhau do Una, região do município do Mojuí dos Campos, acionou a ambulância pra adiantar a viagem,o meu cunhado me pegou no carro e ele veio de encontro a ambulância e assim nós chegamos até aqui. ”Sujeito 3
\end{abstract}

“...ai eu fiquei apavorado, chamei meu amigo que tava lá comigo pra nós ir embora, não dava tempo de chega em casa, ai ainda cortei o pé na outra hora, ai peguemo o carro, ainda tomei banho em casa, peguemo o carro viemo pro posto de saúde lá não tinha contra veneno, ai encaminharam pra cá pra cidade, ai chegou na comunidade de Boa Esperança nós peguemo outro carro que é a ambulância. Da comunidade do Boralá para comunidade de Boa Esperança são uns 20 quilômetros de distancia ai de lá nós pegamo a ambulância e cheguemo até aqui. "Sujeito 4

A distância percorrida pelas pessoas até a assistência e o tratamento específico foi obstáculo, evidenciado nos depoimentos. A maioria dos casos era proveniente de regiões distantes, tendo sido necessário recorrer a transporte público ou particular, o qual, de acordo com o relato de alguns, não era disponível no momento do acidente, o que tornou a trajetória ainda mais difícil.

Entretanto, apesar da dificuldade de acesso às informações, os pacientes são detentores de uma vasta experiência sobre a natureza, a diversidade de animais e dos possíveis acidentes, devido ao contato direto com a floresta. Também são conhecedores de algumas medidas de prevenção, como por exemplo, o simples uso de botas, muito comum ao homem do campo, que pode evitar diversos acidentespor animais peçonhentos.

Em todos os depoimentos, a família, vizinhos e conhecidos foram mencionados como apoio fundamental na busca de cuidados, com o auxílio de transportes, ajuda financeira e 
busca de socorro para o tratamento contra os sintomas ocasionados pelo veneno. Ou, até mesmo com conselhos, de experiências anteriores, como a utilização de medicamentos caseiros e terapia medicinal utilizados em outras vítimas.

\begin{abstract}
"ai ele voltou pra casa,ai o meu genro trouxe ele de moto até o Jamaracua, chegando lá não tinha carro, passemo pra outra comunidade, chegamolá, a professora trouxe até Belterra, lá foi medicado, passado dipirona, e daí trouxeram, o SAMU trouxe até aqui no municipal...." Sujeito1.
\end{abstract}

"Eu e теи irmão pegamo o carro e viemo pro hospital.Viemo até a UPA, chegamos na UPA não tinha material, medicamento pra esse tipo de soro, trouxeram a gente pro hospital municipal, aqui que a gente recebeu o primeiro atendimento. "Sujeito 2

Nas trajetórias percorridas, relatadas nesta pesquisa, observou-se contextos que envolvem principalmente os princípios e diretrizes do Sistema Único de Saúde (SUS), como por exemplo, a assistência recebida pelas vítimas, assim como, as experiências e concepções dos sujeitos e seus familiares no contexto político, econômico, social e demográfico no qual estão inseridos.

Os fragmentos 12,13 demonstram os momentos de afliçãodas vítimas, que envolve a participação familiar na trajetória percorrida, e como estas se organizam perante o acidente.

\begin{abstract}
"Rapidinho vesti uma roupa, meu marido arrumou as coisas! Eu subi uma subida correndo! quando eu to bem normal eu nem guento quase subi a subida, eu subo bem devagazinho, e aquele dia com chuva ele me levou até no pé da ladeira de moto, eu subi correndo! Até onde tava a caminhonete! Cento e poucos metros, subi correndo, quando eu cheguei lá na caminhonete sentei lá dentro da caminhonete esperando eles arruma as coisas.... Na verdade eu vim correndo até na caminhonete, da caminhonete que ele veio comigo, daí aqui eles me carregaram que num agüentava, eu tava tudo dura né? meus pé, minhas mão." Sujeito 12
\end{abstract}

"Eu providenciei o carro, ai levamo, ai minha esposa veio, eu fiquei em casa cuidando das outras filhas, garotinhas que são pequena, uma de 1 ano e a outra de 7 anos, ai quando chegou aqui no hospital ai tem aquela demora de fazer a papelada, aquela coisa toda, ai o que acontece, ai num tinha o medicamento, já veio chega já, isso foi domingo a noite né, o médico chegou umas 10:00 horas do dia no domingo, ai veio o medicamento pra ela toma. "Sujeito 13

O eixo mais importante do IT não é discutido na maioria das pesquisas e que se refere à relação de tensão entre as pessoas e as instituições de cuidado, que precisa ser respondida no âmbito do Sistema Único de Saúde (SUS), em que um dos princípios é a universalização, que inclui a responsabilidade de atender as diversas necessidades em todos os níveis de atenção. Entretanto, diversas lacunas são apontadas como restritivas à concretização desse princípio (BELLATO et al., 2008). 
O Sistema Único de Saúde (SUS) apresenta lacunasque dificultam a busca de atendimento e socorro aos agravos dos indivíduos, como por exemplo, a falta do soro antiescorpiônico nas UBS das comunidades e até mesmo a falta de manejo e qualificação dos profissionais com o agravo, relatado pelos mesmos.

É essencial a interação entre as necessidades de saúde e a organização do sistema de atenção à saúde, para que estas sejam atendidas com efetividade. No entanto, o que ocorre é uma discrepância entre as necessidades epidemiológicas, frequentemente com predomínio decondições crônicas, com baixa acessibilidade e longitudinalidade, evidenciando-se sistemas fragmentados voltados a atender as situações agudas ou eventos de agudizações decorrentes de situações crônicas (MENDES, 2012).

Brasil (2008) corrobora os achados deste estudo, ao enfatizar que o vínculo nas instituições é o encontro entre o usuário e o trabalhador de saúde. Neste, ambos possuem intenções, necessidades, razões e sentimentos, no entanto, concretiza-se em um momento instável, em que o usuário busca assistência e o profissional deveria responder com o atendimento, cuidando da fragilidade apresentada. $\mathrm{O}$ vínculo criado geraria afeto, respeito e ética entre ambos.

No excerto 17 , uma criança foi vítima do acidente, e sua genitora indignada relatou a trajetória e a conduta do profissional que atendeu a criança na UPA e a encaminhou para o Pronto Socorro Municipal.

“Ai ele correu, chamou o vizinho que tem carro, ai a gente veio pra UPA, ai quando
chegou na UPA, quando agente tirou ela do carro ta horrivel já o choque, o corpo
dela todinho tremendo! Ai botemo lá, passou direto, atenderam ela, ai a moça disse:
olha vou da um remédio pra dor aqui! Ela tava com muita dor! Mas aqui a gente
não tem o soro, ela tem que toma, e nem tavam fazendo coleta, do exame, ela vai
ficar 6 horas de observação, ai com 6 horas a gente vai vim aqui, qualquer coisa a
gente manda pro municipal. Como aumentou o choque, ela chamou o meu esposo e
disse: olha pai melhor levar ela pro municipal! Logo! Ai eu pensei que eles iam
mandar o carro de apoio trazer né? Ai tipo assim... se vira né? Ai lá vai o meu
esposo, sorte que o vizinho tinha ficado lá na frente, botemo de volta no carro e
trouxemos pra cá, ai chegou aqui, foi logo atendida ela né? Ai trouxeram ela pra lá
ai aplicaram logo o soro, trouxeram pra cá pra esse quarto aqui...”Sujeito 17

O profissional que atua no enfrentamento do escorpionismo deve ter sensibilidade e comprometimento perante as condições e a gravidade do acidente, conduzindo o caso com a certeza de que o usuário foi acolhido, assistido e tratado com dignidade e respeito, levando em consideração o sofrimento e as possíveis complicações.

Assim, denota-se que há necessidade de capacitação dos profissionais que recebem vítimas destes agravos, que apresentam peculiaridades em sua sintomatologia, que preocupa 
os familiares. Portanto, é necessária a sensibilidade e o compromisso ao conduzir estasituação,que requer olhar acolhedor.

$\mathrm{Na}$ condição de pesquisadora e receptora dos relatos, emocionei-me algumas vezes, ao ouvir as trajetórias comoventes, momentos de angústia e sofrimento diante da necessidade de buscar cuidados urgentes, em consequência da gravidade do acidente, que em alguns casos não foi uma assistência adequada, digna e humanizada, como demonstra os discursos dos sujeitos.

\section{Tema 3: Providências após a ocorrência do acidente (“a ferroada").}

As atitudes iniciais, após a picada, podem determinar o desfecho do estado clínico do paciente. Por isso os primeiros socorros, realizados adequadamente, são imprescindíveis, assim como identificar a espécie do escorpião.

Nesse contexto, evidenciou-secondutas inadequadas para o acidente escorpiônico:

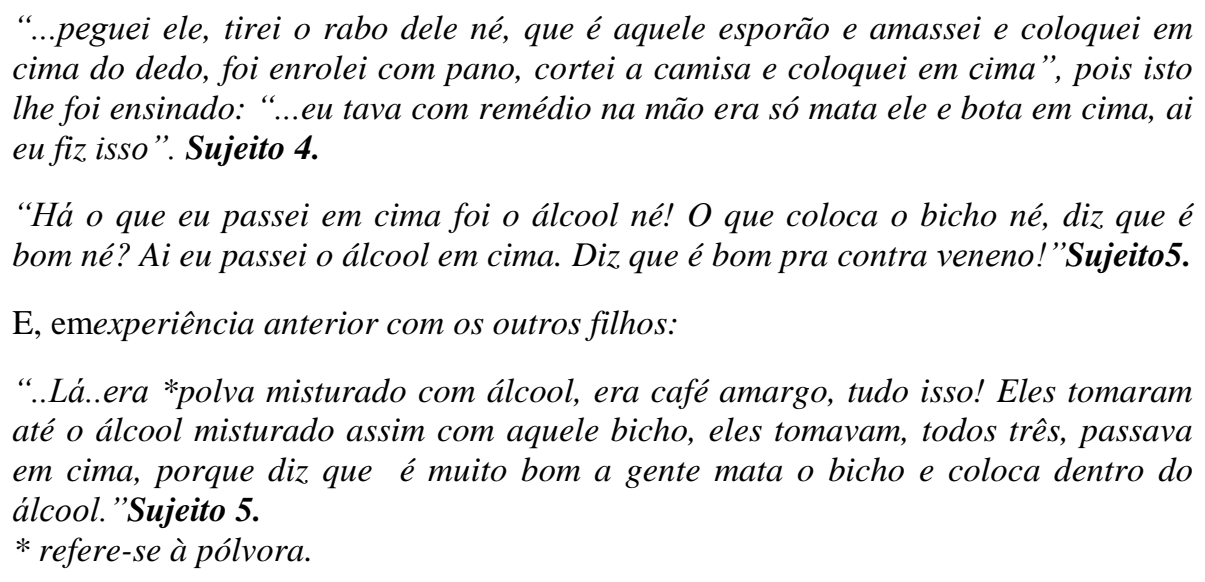

A maior parcela dos sujeitos tomou atitudes caseiras, baseadas em experiências similares às de seus familiares ou conhecidos, o que denota não estarem suficientemente informados sobre as práticas corretas ao se depararem com a sintomatologia.

Algumas das práticas mais relatadas pela maioria dos sujeitos foram: fazer torniquete para impedir a circulação sanguínea, cortar o local, aplicar querosene, cebola, ou tabaco no local da picada:

\footnotetext{
“...eu ainda pensei assim em cortá meu dedo assim...não eu vou corta meu dedo pro veneno sai com o sangue, ai falei... ai não tinha nenhuma faca lá na hora, só tinha um punhal mesmo, só que era muito grosso."

"Foi! O meu cunhado que falou. Olha quando alguma coisa te pica,...tu faz um corte assim...o veneno pode sai!’ Sujeito 6.

“..nós fomo na casa do meu avó pega tabaco pra amarrar com óleo."

"Foi o meu avó que pegou óleo, de lá o papai foi perguntá o que que era pra passa. Ele num ia me trazer pro hospital não por causa que num tava muito grave, de lá foi
} 
coizando, de lá eles rapidinho, me truxeram. Minha língua travou, fiquei com coisa é...com a perna dura." Sujeito 11.

“ nós colocamos um óleo elétrico com tabaco. Café com água... café amargo, forte. o café amargo aguado na água, foi isso que ela tomou." Relato do pai do Sujeito 11.

E o relato de outrasexperiências:

“Isso! É! geralmente fazem! Tanto pro escorpião quanto pra...todos eles fazem o remédio caseiro lá, uns funcionam, outros não (Risos..). ...eles cortam a cebola e põe em cima pra puxa o veneno, eles cozinham o ovo e põe em cima, eles dizem que a... aquela gema do ovo puxa o veneno, são várias coisas que fazem, ou eles cortam a região pra espremer o sangue né? E assim, são esses basicamente os remédios que eles fazem lá." Relato do pai do Sujeito 11.

\begin{abstract}
"Eu num passei nada não. Eu só fiz cortar onde ela picou pra saii o sangue, pra vê se o veneno sai, mas num adiantou nada, cortei mas num adiantou não, num saiu quase sangue..algumas pessoas que fala.... ai eu fui e cortei pra vê se sai o veneno, que num atinge muito o veneno, se cortar e sai o sangue ela num atinge assim o corpo todo, ai eu num agüentei nem cortar porque eu num agüentava cortar, só pra gente que tem coragem mesmo de cortar, ai eu cortei só um corinho mesmo mas num sai sangue não quase. Se eu tivesse cortado ia saí bem sangue mesmo, ai ela num ia... mas eu acho que assim mesmo cortando ela faz efeito, é rápido demais!" Sujeito 15.
\end{abstract}

Estas são algumas atitudes comuns da região Amazônica, mas que não contribuem para a evolução clínica do acidente. De acordo com a Fundação Nacional de Saúde (2009), após o acidente é necessário adotar algumas medidas imediatamente: limpar o local com água e sabão, procurar orientação médica imediatamente (UBS, Hospital), capturar o animal se for possível e levá-lo ao serviço de saúde para ser identificada a espécie e, assim, estabelecer o tratamento específico.

Torrez (2016), em sua tese de doutorado, também obteve resultados que se assemelham aos deste estudo, como amarrar (fazer torniquete), cortar com a finalidade de "eliminar as toxinas pelo sangue", ou ainda aplicar substâncias no local da picada, banha, folhas, álcool, água morna, dentre outras.

Poucos sujeitos relataram condutas adequadas, como demonstra o excerto a seguir:

“...É..apenas foi lavado o local, com água e sabão e.. disseram que era bom tomar água morna e eu tomei, e foi só isso até eu chegar aqui na unidade de saúde hospital. 'Sujeito 3.

Orientações sobre o que não deve ser feito: amarrar ou fazer torniquete; aplicar qualquer tipo de substância sobre o local da picada; cortar, perfurar ou queimar o local da picada; oferecer bebidas alcoólicas ao acidentado, ou outros líquidos como álcool, gasolina, entre outros, também estão contemplados no Manual da Fundação Nacional de Saúde (2009). 
Neste tema, observou-se a valorização e o uso singular da medicina natural, procurada com frequência pela população local. O uso de medicamentos fitoterápicos na região Oeste do Pará é uma prática cultural, para tratar ou remediar agravos e patologias, além de ter se tornado também uma fonte de renda para a comunidade local. No mercado de Santarém (Mercadão 2000), o comércio é intenso e atende diversas demandas da população como escolha terapêutica para atender suas necessidades de saúde.

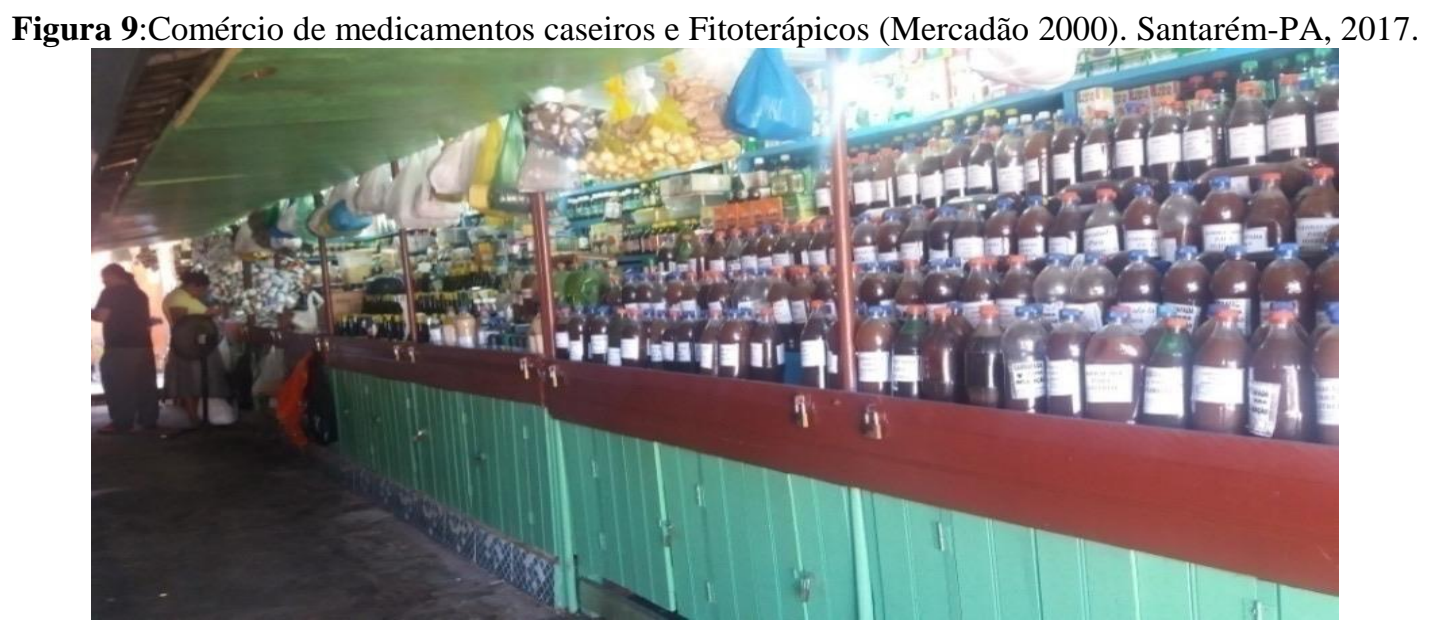

Fonte:Acervo fotográfico da autora (2017).

Tanto os medicamentos fitoterápicos, que são produzidos com matéria-prima extraída de plantas medicinais, quanto os caseiros, são utilizados para tratar dores, febres, inflamações e outros sinais/sintomas e são denominados de "contraveneno" que, no caso da picada de escorpião, irá "cortar" o veneno inoculado pelo animal. Tais conhecimentos são culturalmente reconhecidos, valorizados e passados de geração em geração, por familiares e amigos:

\footnotetext{
"Quando ferrou lá nela meu marido fez...deu um café amargo pra ela e fez uma fumaça assim da casca do ovo e algumas coisas, remédios lá e dela num deu essa coisa como deu nesse..." Sujeito 1.

"Foi nós colocamos um óleo elétrico com tabaco. Café com água parece que a XXX fez lá. $O$ café amargo, forte. $O$ café amargo aguado na água, foi isso que ela tomou... geralmente fazem! Tanto pro escorpião quanto pra...todos eles fazem o remédio caseiro lá, uns funcionam, outros não (Risos..). Eu já assim, por exemplo..eles cortam a cebola e põem em cima pra puxá o veneno, eles cozinham o ovo e põe em cima, eles dizem que a... aquela gema do ovo puxa o veneno, são várias coisas que fazem, ou eles cortam a região pra espremer o sangue né? E assim, são esses basicamente os remédios que eles fazem lá." (Relato do pai do Sujeito 11.
}

Em geral, o tratamento caseiro para acidentes com animais peçonhentos, especificamente por escorpião, objeto do presente estudo, é baseado em crenças locais, que 
incluem uso do fumo, beber solução de álcool contendo o animal, aplicar gordura de sucuri ou álcool no local da picada, utilizar óleo misturado com tabaco, beber café amargo. Alguns destes procedimentos também foram reportados neste estudo. Na concepção popular, tais práticas podem eliminar o veneno:

“...Ai eu passei o álcool em cima. Diz que é bom pra contra veneno!’Sujeito 5.

Ou, práticas realizadas com familiares, vítimas de acidentes anteriores:

"Lá..era *polva misturado com álcool, era café amargo, tudo isso! Eles tomaram até o álcool misturado assim com aquele bicho, eles tomavam, todos os três, passava em cima, porque diz que é muito bom, a gente mata o bicho e coloca dentro do álcool. "Sujeito $7 *$ refere-se a pólvora

"Pra combater né? É, é normal, tem contra veneno que a gente toma e fica bom, até aqui no dia que eu tava aqui mais minha sobrinha aqui tinha um cara aqui conversando com a minha sobrinha aqui, que disse que a pessoa que é picado por escorpião se toma uma colher de querosene diz que num senti nada! Querosene que ele falou, tem várias coisas que toma, é o contraveneno." Sujeito 7.

A maioria dos sujeitos entrevistados alegou que tais práticas populares são eficazes, recomendando seu uso. No entanto, alguns se contrapõem e desaconselham, pois acreditam que depois que o veneno é inoculado no organismo da vítima, nada há mais a ser feito.

"É...o pessoal, tem muitos deles que usa elixir, como é meu Deus? Um tipo de
remédio lá, um contra veneno, um pau chamado! Eu nunca tumei não e eu acho que
num adianta não, depois de ser picado, que o veneno contamina logo o corpo né? E
essa foi uma das mas rápida, porque! Quando as duas me picaram eu ainda cheguei
a passar uma hora sem o choque, e essa com 15 minutos já fiquei disisperado."
Sujeito 8.

A matéria prima desta diversidade de "medicamentos" é extraída de ervas medicinais, de cascas de tronco de árvores, folhas e sementes de plantas, óleo extraído da andiroba, da copaíba, leite de súcuba (extraído do tronco de uma árvore), sebo de Holanda (pasta branca extraída de uma planta), além de gordura de animais como a sucuri, mel de abelha, entre outras.

Tais substâncias são preparadas e conservadas em recipientes devidamente embalados e identificados, contendo a sua indicação, posologia, e até mesmo as possíveis reações, como demonstra as Figuras 9 e10. A população em geral tem extrema confiança no benefício e resolutividade dessas substâncias, utilizadas em diversos agravos à saúde.

Figura 10:Comércio de medicamentos caseiros e Fitoterápicos (Mercadão 2000). Santarém-PA, 2017. 


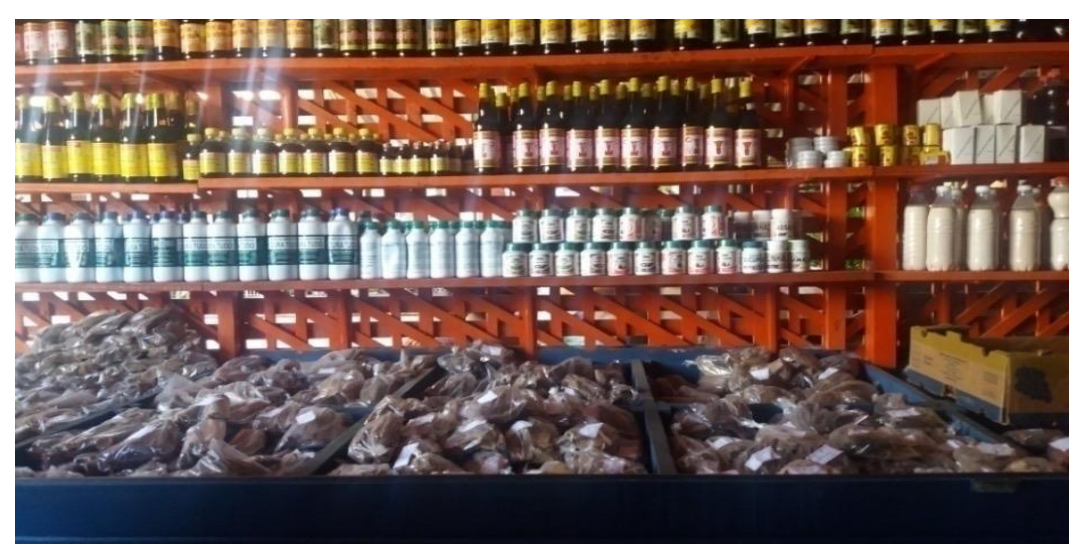

Fonte:Acervo fotográfico da autora (2017).

No presente estudo verificou-se que, para a picada de escorpião, alguns sujeitos mencionaram e recomendaram uma solução muito utilizada, em forma de xarope: o "Pau-x":

\footnotetext{
“Já! Conheço e já vi gente ficá melhor, bom mesmo, num senti nada...é o féu de paca e Pau-x, a senhora já ouviu fala no Pau-x? São dois contra veneno bom pra combater o escorpião. Já vi alguém fazer. Deu certo...diz que é muito bom, servi como contra veneno, é amargo! Mas é bom!' Sujeito 10.
}

Especificamente em relação ao Pau-x verifica-se, inclusive, a sua indicação em casos graves, como mostra a figura 11.

Figura 11: Fitoterápico comercializado para tratamento de picada de escorpião (Mercadão 2000) Santarém-PA, 2017. 


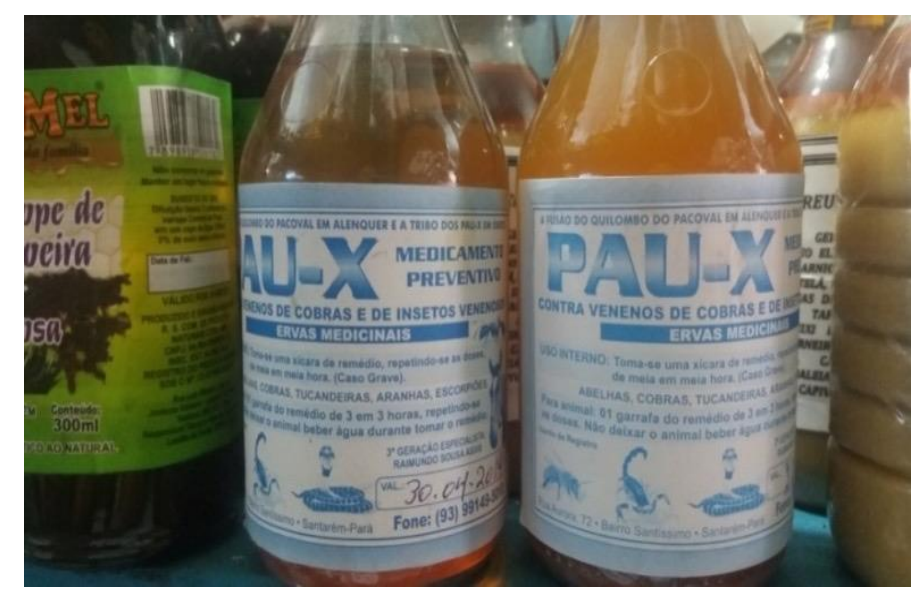

Fonte:Acervo fotográfico da autora (2017).

Tais práticas encontram lugar na Amazônia, onde a cosmovisão do mestiço e do caboclo converteu-se num intrincado amálgama que inclui representações nativas e estrangeiras, como a europeia. É importante compreender a formação do sistema religioso do caboclo, que se estabeleceu singularmente na Amazônia, assim como os processos que o diferenciam etnicamente de outras identidades existentes e como ele interpreta sua realidade a partir desses modelos conceituais (FERNANDO, 2007).

Entretanto, Albuquerque et al. (2009) lembram que nenhuma substância caseira substitui o soro antiescorpiônico. Também orientam a aplicação de medidas para alívio da dor, como compressas mornas, e indicam que, em caso de não regressão do quadro, o paciente deve ser levado ao serviço de saúde.

É importante que a população conheça os procedimentos corretos a serem realizados por ocasião desse agravo, e que podem ser divulgados amplamente em escolas, no trabalho, nas unidades de saúde, em espaços coletivos. As instituições de saúde e educação são responsáveis por disseminar tais informações e instrumentalizar a população sobre as formas mais adequadas de intervenção nesse tipo de agravo (PEREIRA; OLIVEIRA, 2014).

Mais do que isso, Oguisso et al.(2017, p. 19) argumentam que:

\begin{abstract}
A promoção da saúde busca articular saberes técnicos e populares, a partir de uma concepção ampliada do processo saúde-doença e seus determinantes. Nessa concepção, profissionais e usuários podem trabalhar juntos ao enfrentamento de diversos problemas e necessidades de saúde.
\end{abstract}

Trata-se da concepção de saúde a partir de um conceito que envolve a interação de diversos atores que, juntos, viabilizam estratégias para minimizar o agravo causado.

Considerando os relatos dos sujeitos sobre as condutas realizadas após a picada de escorpião, é perceptível a necessidade de desenvolver práticas educativas, para que as 
pessoas mantenham-se informadas da gravidade do acidente e pratiquem as condutas corretas.

\section{Tema4: Manifestações clínicas apresentadas pelas vítimas dos acidentes escorpiônicos.}

O tema sobre a sintomatologia apresentada revela indícios de que a maior parte dos acidentes foram moderados ou graves, uma vez que foi necessária a internação da pessoa que sofreu o acidente, além da administração do soro antiescorpiônico associado a outros medicamentos.

Os sinais e sintomas decorrentes da picada do escorpião, na maioria das vezes, são desconhecidos pela população em geral, particularmente aqueles causados pelo Tityus obscurus, de cor negra e mais prevalente na região Amazônica: dor local intensa, frequentemente irradiada, edema discreto e sudorese local; em casos graves pode-se observar alterações cardiovasculares e edema agudo de pulmão (BRASIL, 2001).

Os sujeitos do estudo, em sua maioria, mencionaram a sensação de choque elétrico, formigamento, dormência, dor local intensa que irradiava para outros locais, dificuldade para falar, para andar, para respirar e queimação, dentre entre outros sintomas:

“... choque, não conseguir deambular, “...começou se babar, começou se tremer tudinho"... aquele choque dava nele... deu alergia nele...; estava "desorientado" (não se lembra como chegou no Hospital Municipal).” Sujeito 1.

"Dor na parte que foi picada, após... ai subiu pro corpo o choque, começou a prender a garganta e o suspiro, no andar foi difícil também, as pessoas que me levavam, não tive condições de andar por causa do choque que era demais, perdi a força, os movimentos das pernas". Sujeito 2.

"Começou um formigamento no local da picada e foi subindo pelo meu braço, aí eu já comecei sentir na outra mão...” Sujeito 3.

"O que eu senti? Foi um tremor na carne, no músculo, todo corpo, até no coro da cabeça. Tremia, mas era só por dentro, não era tremor de ficar né? ... Choque, mas sentia que por dentro tava dando, mas assim pra da choque mesmo pra ta pisoteando não. Depois que eu tomei o remédio aqui, o contra veneno, que eu nem sei dizer como é que o nome me deu um suador grande, eu tirei até a camisa ai me abanaram aqui, que pra mim ia da uma agonia, fiquei todo impolado e vermelho. Ficou meio escura a minha vista, a língua quis embola, mas não embolou ficou assim tipo grossa, mas não embolou. Eu andei meio ruim, porque tava meio dormente meus pés, pra mim eu não tava pisando no chão. ”Sujeito 4.

"No local, formigando, formigando, formigando, até o corpo todo formigava! Aí, depois veio aquele frio, frio, frio! Me contorcia assim! Veio o choque! Até agora o choque." Sujeito 16. 
De acordo com os relatos, o surgimento dos sintomas é geralmente imediato, a dor se inicia no momento da ferroada e aumenta de intensidade. Os demais sintomas começam a surgir dentro dos primeiros 15 minutos após o acidente. Entretanto, o período de tempo para a ocorrência dos sintomas pode variar para cada paciente.

A literatura evidencia que a sintomatologia depende de fatores como a espécie de escorpião, a quantidade de peçonha inoculada, a idade da vítima, sua massa corporal, sua sensibilidade ao veneno, dos mediadores químicos liberados, do tempo entre o acidente e o estabelecimento do tratamento, da conduta nos primeiros socorros, entre outros (ZOCAL, 2014).

Ciruffo et al. (2012, p. 30) descrevem os quadros grave e moderado:

Os casos moderados a grave são observados principalmente em crianças e
progridem com exacerbação do quadro local e manifestações sistêmicas. Nos
moderados, ocorrem algumas manifestações sistêmicas isoladas e pouco intensas
como náuseas, vômitos ocasionais, sudorese discreta, taquicardia, taquipneia e picos
hipertensivos leves. Já os graves cursam com o agravamento do comprometimento
geral do paciente e das manifestações sistêmicas como sudorese profunda, vômitos
incoercíveis, salivação excessiva, alternância entre prostração e agitação,
bradicardia, insuficiência cardíaca, edema agudo de pulmão, choques, convulsões e
coma. As manifestações cardiorrespiratórias, particularmente o edema agudo de
pulmão e o choque, são as principais causas de óbito no acidente escorpiônico grave.

Os casos leves não necessitam de soro antiescorpiônico, mas requerem observação. Já o moderado e o grave sempre necessitam de internação, uso do soro e condutas médicas apropriadas para estabilizar a vítima.

A gravidade é mais comum em crianças e idosos; os sintomas são intensos e agressivos, causando sensação de angústia na vítima e desespero de quem acompanha a pessoa durante as primeiras $12 \mathrm{~h}$ após a picada.

As manifestações locais e sistêmicas em decorrência da picada do escorpião, na maioria das vezes, são desconhecidas pelas vítimas. Quando possuem experiências anteriores com o acidente, tendem a sentir angústia e medo, mas entendem que se trata de sintomas causados pelo veneno do escorpião e que o tratamento específico irá controlar.

No entanto, os que se deparam pela primeira vez com a sintomatologia,tendem a sentirangústia, medo da morte,e este sofrimento tende a levá-lo ao desespero, como se verifica nos fragmentos 5,12.

“... dor local, edema no local da ferroada: pé; ...ele não queria se acalmar, gritando, gritando, gritando”; “...Era uma quentura imensa, e ele gritava, eu tive que tirar toda a roupa dele....eu fiquei perturbada (mãe), ... parece que ia morrer porque uma vez pra lá, já tá com uns 3 anos, morreu uma criança picada disso, ele tava com sete 7 anos! Ele não resistiu! Por isso que eu trouxe ele né,... se eu 
ficasse lá eu tinha certeza que ele não ia aguentá, foi a noite inteira gritando e se entortando, ele pegava o meu cabelo e me mordia todinha! Já quando foi de manhã..pronto! Já hoje de tarde passou o dia dormindo, ai a noite coloquei ele na cama, ele ta até com o rosto inchado ele dormiu de bruços, ele acordou agora de manhã, ele só ta convidando pra ir embora pra casa!" Sujeito 5.

"E já começou a latejar o pé, e eu falei num é nada não! É igual formiga!... "A primeira coisa que eu senti foi outra picada parece no corpo e na garganta que foi tacando a garganta e daí já começou o corpo inteiro até a cabeça assim, pescoço, peito, parecia que ele tava mordendo nos peito assim tudo. Mesma picada que eu tinha sentido aquela hora, eu sentia assim mordendo e o choque! O choque é demais! o choque sempre que a caminhonete dava uma maneirada na quebra-mola parecia que o choque partia tudo assim, parecia que eu ia morrer daquilo, a sensação que eи ia morrer daquele choque sabe? Que tava muito forte!... “..eu num agüentava falar, só...minha garganta tava travada, isso aqui parece que ele começou morder de novo aqui nesse braço, ai começou morder no corpo assim e a minha garganta parece que tava trancada, sensação ruim de muito choque! Muito choque! Num agüentava mais de choque! Aquele tremor, aquela coisa e eи num aguentava falá de jeito nenhum e minha vista já escureceu, num conseguia mais enxergar." Sujeito 12.

Um relato que chamou a atenção, em relação à sintomatologia, foi apresentado por uma criança de 12 anos de idade. O acidente ocorreu em zona urbana, no interior do domicílio, aproximadamente às 21 horas.

O início da sintomatologia difere dos outros relatos do estudo, pois no momento da picada sentiu somente dor leve, no entanto, por volta de 5 horas da manhã, a criança começou a apresentar choque e alucinações, ou seja, cerca de 8 horas após a picada.

Este evento difere dos demais casos, em que as vítimas apontam que o iníciodos sintomas ocorre logo após a picada, e o choque com 15 minutos ou 30 minutos, no máximo 2 horas, fragmento 8,13 .

"Ela ficou variando! Falando besteira, falando coisas assim. Eu to vendo um cachorro! E a dor!' Sujeito 13.

"Na hora que picou? Queima! parecendo aquelas ferrada de caba, dueu, mas só que parou! Eu fiquei calma!... "eu só fui senti umas 5 horas da manhã, o choque e a dor! E ai eu fiquei ruim da cabeça, não sabia, mas o que eu ia falá, da vista, também eu fiquei ruim." Sujeito 13

\footnotetext{
"Quando as duas me picaram eu ainda cheguei a passar uma hora sem o choque, $e$ essa com 15 minutos já fiquei disisperado.......eu perdi as pernas rápido, é...em 10 minutos eu já tinha perdido as perna, eu não conseguia mais andá, já foi preciso me butarem na ambulância, jogado mesmo, eu num cunseguia mais andar. Ai o choque, mas o choque porque a cada vez que a ambulância batia no chão, ai balançava, é porque o escorpião muitas vezes controla pelo fulgo*, se você prender o fulgo que quando você se solta, só falta estoura o peito..." Sujeito 8.

*O participante se refere à "fôlego".
} 
O restabelecimento das vítimas do escorpionismo do presente estudo foi positivo, pois apresentaram boa evolução clínica, em geral, sem complicações posteriores, não tendo havido óbito. No entanto, demonstraram muito medo em relação à sintomatologia apresentada, o que evidencia a necessidade de divulgação de informações a respeito, assim como do manejo apropriado da vítima. Isto tornaria mais fácil aos familiares conduzirem a situação, em que as vítimas se apresentam, pois é necessário tranquilidade e observação contínua da vítima até que o tratamento amenize a sintomatologia.

\section{Tema 5:0 que foi feito com o escorpião(lacrau)?}

Em relação a este tema, os sujeitos relataram condutas inadequadas com o que foi feito com o escorpião, mas que em geral são comuns pela população de zona rural da região local. As condutas mencionadas partem de conselhos de familiares ou vizinhos que já haviam passado pela experiência do acidente escorpiônico.

A maioria dos sujeitos relatou ter matado, queimado, desprezado, ou colocado o animal em álcool. Outros, o utilizaram morto e macerado no local da picada, e uma minoria levou o escorpião à unidade de saúde para sua identificação, que é a conduta correta; as duas situações são demonstradas nos fragmentos 4,5,11,12.

"Peguei ele tirei o rabo dele, né, que é aquele esporão e amassei e coloquei em cima do dedo, foi enrolei com pano, cortei a camisa e coloquei em cima" Sujeito 4.

"Eu coloquei no álcool, ficou lá em casa. Porque lá a gente mata e vai colocando tudo no álcool." Sujeito 5.

“A minha prima matou! Vi na hora que ele me mordeu, aí ela puxou, ele já ia correndo." Sujeito11.

"Matemo ele!! Trouxe até ai! ( mostrou o escorpião negro morto em uma sacola) E é grande viu! O escorpião preto bem grande viu!’ Sujeito 12.

"Há esse escorpião ele ficou na garota e veio pro pessoal confirma que era o escorpião, é o correto isso? Eu peguei o intestino dele, abri, coloquei num pano e amarrei onde ele picou a garota. É bom trazer o inseto assim né..pra confirma que aquilo foi. Esse que veio era preto, bem longo, grande. Porque quando a gente traz a serpente ou cobra que pica, que seja o escorpião, ou uma espécie de aranha né? É bom a gente trazer porque ai o médico vai vê...pra vê o qual é o tipo, que ele é são vários tipo né? Tem do preto, tem do roxo, tem do vermelhinho, é como a cobra, ai o cara chega, ah! a cobra mordeu a minha filha, que cobra foi? Você trouxe a cobra? Você viu? Não num vi, ai fica atrapalhado né? porque pega aquele veneno certo pra medica o paciente." Relato do pai do Sujeito 13.

"Eu num tava vendo, aí eu procurei assim, na hora que eu vi ele já pegou o pau. Eu ainda falei assim, não! guarda aí que eu vou leva. Ai não porque já tava tudo amassado já." Sujeito 6. 
Levar o escorpião para o serviço de saúde é necessário após um acidente escorpiônico, para que este seja identificado e assim iniciado o tratamento específico, além de confirmar se se trata de acidente escorpiônico. A identificação do escorpião é recomendada pelo Ministério da Saúde e por alguns autores (ALBUQUERQUE et al., 2009).

No entanto, a maioria das pessoas desconhece esta informação e acaba matando e desprezando o animal:

\author{
“Matei ele! Preto!” Sujeito 16. \\ “O meи esposo matou ele, e a minha sogra queimou ele!’Sujeito17. \\ “Pegamos ele vivo e botamos dentro de um vidro e tampamos. "Sujeito18.
}

Outra situação mencionada por alguns sujeitos foi a dificuldade para capturar o escorpião, pois após a picada, em geral, os animais fogem ou se escondem em folhagens, madeiras:

\footnotetext{
“....ninguém conseguiu vê, mas, mas a gente sabe que era o escorpião mesmo, que eu já havia sido ferrado. Eu num matei porque eu num vi, num consegui vê, era de noite né?.." Sujeito 7.

"Não! Que quando eu... ele se escondeu, porque o pau ele sempre tem uma brecha, que quando ele pegou, eu vi que quando ele se escondeu, num deu de mata, aí eu sufocado com a dor também deixei pra lá. Ele era preto. ’Sujeito 8.
}

Mesmo que não seja possível capturar o escorpião, mas se as pessoas veem e reconhecem a espécie, ou pelo menos sabem dizer uma característica como a cor, o tamanho, tais dados ajudam na identificação e até mesmo a certeza de que realmente se trata de um acidente escorpiônico. 


\section{CONSIDERAÇÕES FINAIS}

\section{CONSIDERAÇÕES FINAIS}

Os cinco temas revelam a experiência dos sujeitos e a forma como lidam com o agravo escorpiônico. Em relação ao primeiro tema, que se refere às "Condições em que ocorreu o 
acidente", evidenciou-se vulnerabilidade nas três dimensões, individual, social e pragmática, desde a exposição do indivíduo ao acidente, a limitação de informações a respeito do agravo, e a fragilidade das instituições de saúde em garantir acesso a informações adequadas em relação à exposição ao agravo. Por se tratar, neste estudo, sobretudo de moradores da zona rural, entende-se que há importante exposição dos indivíduos ao acidente. Além disso, as condições de vida e de trabalho ajudam a determinar a ocorrência do acidente, assim como o acesso aos serviços de saúde.

No tocante ao tema relativo à "Trajetória percorrida pela vítima até o tratamento", constatou-se uma série de dificuldades, entre as quais, a extensão territorial da região, a necessidade de percorrer várias unidades de saúde até a obtenção do tratamento adequado, pois o soro antiescorpiônico somente é disponibilizado no Hospital Municipal. Também verificou-se dificuldade no manejo do acidente por parte dos profissionais de saúde.

Em relação ao terceiro tema: "Providências após a ocorrênciado acidente", a família é que promove os primeiros cuidados à vítima, muitas vezes a partir de experiências anteriores. São utilizadas terapias fitoterápicas e substâncias caseiras, com a intenção de minimizar a sintomatologia. Esta é uma cultura frequente e muito respeitada pela população local, considerada uma opção segura no enfrentamento da sintomatologia decorrente do agravo. No entanto, certas atitudes podem complicar as condições da vítima.

No que diz respeito ao tema "Manifestações clínicas apresentas pelas vítimas do acidente escorpiônico", identificou-se a precocidade e a intensidade dos sinais e dos sintomas, e o desconhecimento e despreparo da população em lidar com estas manifestações.

No que tange ao último tema, “O que foi feito com o escorpião?”, verificou-se que há desconhecimento sobre as condutas corretas após a picada. Os dados analisados no presente estudo permitem entender que não há uma política de saúde, que trabalhe na disseminação de informações sobre o agravo escorpiônico, incluindo a sintomatologia, as medidas de primeiros socorros com a vítima, as principais espécies causadoras dos acidentes de importância médica na região, o tratamento específico, entre outras. Dessa forma, seria recomendável a elaboração de materiais educativos, contendo as orientações necessárias para a população, que pudessem ser distribuídos gratuitamente e discutidos nas comunidades, de preferência nas regiões onde ocorreo maior número de acidentes. Na tentativa de suprir essa lacuna, apresentar-se-á uma proposta de material educativo. Uma cartilha, no formato de história em quadrinhos, e um cartaz, contendo informações sobre o escorpionismo. 


\section{CONCLUSÃO}

\section{CONCLUSÃO}

As dificuldades enfrentadas pelas vítimas de acidente escorpiônico, atendidas no Hospital Municipal de Santarém, reveladas neste estudo, incluem: a dificuldade de acesso das 
comunidades rurais aos serviços de saúde, onde há o tratamento específico para o acidente escorpiônico; a falta de soro antiescorpiônico próximo às comunidades, assim como profissionais com competência para administrá-lo, o que poderia minimizar o sofrimento da vítima; a "agressividade" dasmanifestações decorrentes do acidente e que, em geral, são desconhecidas pela população.

Evidenciou-se que a vítima de acidente escorpiônico é vulnerável ao acidente nasdimensões individual e social, principalmente em decorrência de sua inserção social e consequentes condições de vida e de trabalho; mas também em relação à dimensão programática, devido às dificuldades de acesso aos serviços dotados de tratamento adequado, assim como falhas na competência de profissionais de saúde (em unidades percorridas até a unidade hospitalar dotada de tratamento correto) para manejar o acidente escorpiônico. Também verificou-se a necessidade da disponibilidade de ambulância, dada a dificuldade de acesso dos pacientes ao transporte público ou privado.

Entretanto, é necessário mencionar que, no Hospital Municipal de Santarém, verificou-se que o tratamento adequado sempre foi estabelecidorapidamente.

A utilização de práticas populares é muito comum no atendimento de primeiros socorros no acidente escorpiônico; percebeu-se que os sujeitos do estudo as acolhem com muitasimpatia, e que tal cultura é repassada de geração em geração. No entanto, aponta-se que não há comprovação de seu benefício no tratamento do agravo escorpiônico.

O estudo permitiu propor ações educativas sobre o acidente escorpiônico, a serem difundidas entre a comunidade. Como profissional da saúde, compreendo anecessidade de contribuir com a população que, na maioria das vezes, é desprovida de informações em relação à gravidade do acidente, ao reconhecimento do animal, acerca das medidas corretas após a picada, sobre a sintomatologia e sobre a busca por tratamento específico.

É importante destacar que as conclusões deste estudo serão apresentadasaos gestores de saúde do município de Belterra-PA, município vizinho que demandou o maior número de pacientes encaminhados ao Hospital Municipal de Santarém.

Destaca-se, ainda, que arealização de uma intervenção que contemple o maior número de comunidades da região da Flona do Tapajós (Belterra-PA), e que permita avançar no compromisso de estabelecer um diálogo entre profissionais de saúde e população local, é de extrema relevância, pois, nessa troca de experiências, poderão surgir sugestões ou propostas de melhoria na acessibilidade da população aos serviços de saúde. 


\section{PROPOSTA DE INTERVENÇÃO}

\section{PROPOSTA DE INTERVENÇÃO}

O estudo intitulado "Acidente escorpiônico no município de Santarém-PA: características epidemiológicas e trajeto percorrido pelos pacientes até o serviço de saúde" foi desenvolvido a partir da seguinte pergunta: Como as pessoas vítimas de acidentes por escorpião procedem após o acidente até o atendimento hospitalar? A proposta de intervenção 
como resultado do estudo está centrada em ações educativas nas regiões onde houve maior número de acidentes durante a coleta de dados. E, como material de apoio na intervenção, propõe-se a elaboração de uma cartilha, no formato de história em quadrinhos, e um cartaz, contendo informações sobre o escorpionismo. Nestes, serão desenvolvidos os temas:

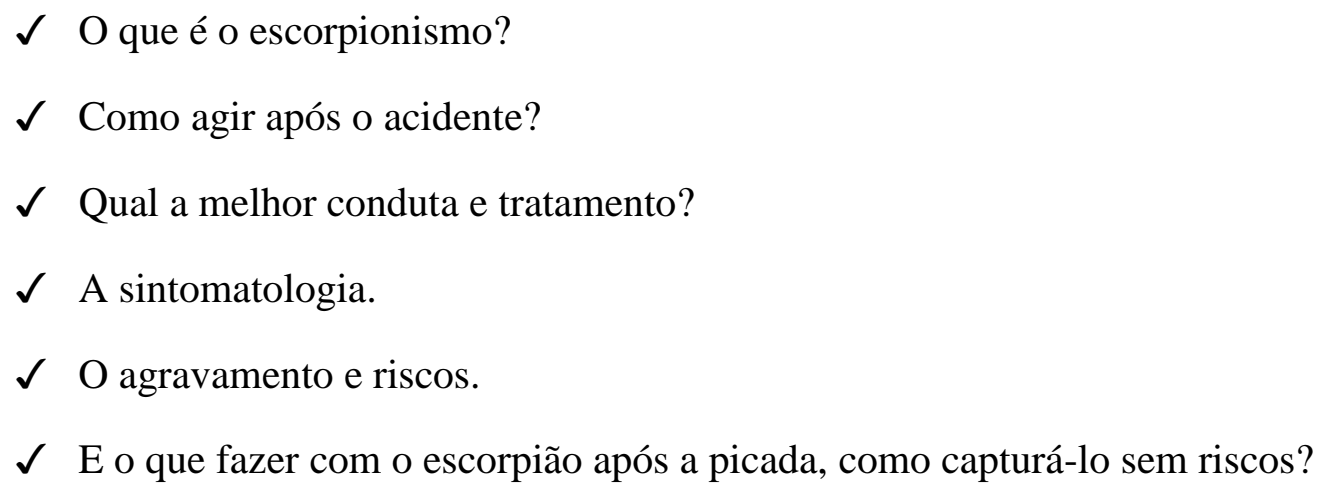

\section{A proposta de intervenção será composta por três fases:}

Primeira fase: apresentação da proposta aos gestores de saúde do Município de Belterra, a partir dos resultados deste estudo. Também será abordada a importância do agravo como problema de saúde pública e a relevância da implementação desta intervenção, informando a população sobre o tema, suas complicações e riscos.

Segunda fase: Apresentação e treinamento de profissionais da saúde de Belterra e comunidades vizinhas, acadêmicos de enfermagem, onde serão abordados os resultados do estudo, e o papel dos profissionais de saúde no manejo do agravo. Estes profissionais serão treinados e convidados para integrar a terceira fase.

Terceira fase:Realização da intervenção junto à população das comunidades da Flona do Tapajós, como Jamaracuá, Maguari, entre outras, onde ocorreu o maior número de casos de escorpionismo atendidos durante a coleta de dados deste estudo. A intervenção terá como população alvo Agentes Comunitários de Saúde (ACS), representantes e líderes comunitários, e a população em geral de comunidades próximas, de forma a capacitá-los para que sejam multiplicadores do manejo correto à vítima de escorpionismo. Os profissionais de saúde capacitados na segunda fase desta proposta serão convidados a integrar a fase 3 .

\section{Dinâmica da Intervenção da $3^{\text {a }}$ fase:}

Serão separados grupos de 10 pessoas. Os profissionais iniciarão abordando o contexto do estudo, seus resultados, estimulando a troca de experiência entre os participantes e, em seguida, desenvolverão os temas disponíveis na cartilha: 
* O que é o escorpionismo?

* Como agir após o acidente?

* Qual a melhor conduta e tratamento?

* A sintomatologia.

* O agravamento e riscos.

* E o que fazer com o escorpião após a picada, como capturá-lo sem riscos?

Os participantes serão convidados a compartilhar experiências individuais sobre o acidente. Buscar-se-á envolver a população para que possa protagonizar a proposição de melhorias no manejo do escorpionismo. 
REFERÊNCIAS 


\section{REFERÊNCIAS}

Ab`Saber A.N. Os domínios de natureza no Brasil: potencialidades paisagísticas. Atelie editorial, São Paulo - SP, 2003.

Albuquerque C.M.R.; Porto T.J.; Amorim M.L.P.; Neto P.L.S.; Neto P.L.S. Eccorpionismo por TityuspusillusPocock, 1893 (Scorpiones; Buthidae) no Estado de Pernambuco. Revista Brasileira de Medicina Tropical. V. 42 nº 2. p. 206-208, 2009.

Ayres J. R. C. M.; Calazans, G. J.;Saletti Filho, H. C. \& França Júnior, I. Tratado de Saúde Coletiva: Risco de Vulnerabilidade e práticas de prevenção e promoção a saúde. - São Paulo: Hucitec; Rio de Janeiro: Ed. Fiocruz, 2006.

Bellato R, Araújo L.F.S; Faria A.P.S; Santos E.J.F; Castro P; Souza S.P.S. A história de vida focal $e$ suas potencialidades na pesquisa em saúde e em enfermagem. Enf.2008;10(3):849-56.

Brazil T.K.; Porto J.P. Os Escorpiões, EDUFBA, Salvador-BA, 2010.

Brasil, Manual de diagnóstico e tratamento de animais peçonhentos. Brasília: Funasa, 2001.

Brasil. Ministério da saúde. secretaria de Vigilância em saúde. Departamento de Vigilância epidemiológica. Manual de controle de escorpiões / Ministério da saúde, secretaria de Vigilância em saúde, Departamento de Vigilância epidemiológica. Brasília : Ministério da saúde, 2009.

Cabral A.L.L.V; Hemaez A.M; Andrade E.I.G; Cherchiglia M.L. Itinerários Terapêuticos: o estado da produção cientifica no Brasil. Ciênc. Saúde Coletiva Vol.16 nº.11 Rio de Janeiro, Nov.2011.

Chippaux J.P.; Goyffon M. Epidemiology of scorpionism: A global appraisal. ACTA TROPICA, V. 107. $n^{\circ}$ 2. p. 71-79, 2008.

Ciruffo P.D; Coutinho L.O; Boroni J.D; Diniz A.E.T; Diniz W.F. Escorpionismo: quadro clínico e manejo dos pacientes graves. Rev. Med Minais Gerais, 2012; 22 (supl 8): s1-s48. Belo Horizonte - MG.

Ciruffo PD; Coutinho LO; Coutinho JD; Diniz AET; Diniz WF. Escorpionismo: quadro clínico e manejo dos pacientes graves. RevMed Minas Gerais 2012; 22 (Supl 8): S1-S48

Costa L.S.O.C. Aspectos epidemiológicos do escorpionismo na região de Santarém, estado do Pará, Brasil. Revista Colombiana ciência animal. V. 4 nº 1. p. 59-68, 2012.

Cupo P. Clinical update on scorpion envenoming. Revista da Sociedade Brasileira de Medicina Tropical V.48. nº, 2015.

Dahlgren, G.; Whitehead, M..Policies and strategies to promote social equity in health.Arbetsrapport/Institutet för Framtidsstudier; 2007:14 
Mendes E. V. O cuidado das condições crônicas na atenção primária à saúde: o imperativo da consolidação da estratégia da saúde da família.Organização Pan-Americana da Saúde, 2012. 512 p.: il.

Fernando, A. A Religiosidade do cabloco na Amazônia. Diário do amazonas, AM, 05/01/2007, p.5.

Fundação Nacional de Saúde. Manual de Diagnósticos e Tratamento de Acidentes por animais Peçonhentos. $2^{\text {a }}$ Ed. - Brasília, 2009.

Gerhardt T.E. Itinerários Terapêuticos em situações de pobreza: diversidade e pluralidade. Caderno de saúde pública 22(11):2449/2463 - Rio de Janeiro, 2006.

Gomes M.A.; Pereira M.L.D. Família em situação de vulnerabilidade social: uma questão de políticas públicas. Artigo Article, Ciências \& Saúde Coletiva. V. 10. n². p. 357-363, 2005.

Horta F.M.B; Caldeira A.P; Soares J.A.S. Escorpionismo em crianças e adolescentes: aspectos clínicos e epidemiológicos de pacientes hospitalizados. Revista da Sociedade Brasileira de Medicina Tropical. 40(3):351-353 mai-jun, 2007.

Instituto Brasileiro de Geografia e Estatística - IBGE. http://cidades.ibge.gov.br/xtras/perfil.php?codmun=150680. Acessado em 30 de junho de 2016.

Instituto Butantan. Acidentes com animais peçonhentos. Revista saúde, São Paulo, V1, n 2015 .

Kleinmam.A.Concepts and a model for the comparison of medical systens a cultural systems.Soc. Sei \& Med. Vol. 12. pp 85 to 93. 1978. Printd in Grean Britain.

Lewinsohn T.M; Feitas A.V; Prado P.I. Conservação de i0nvertebrados terrestres e seus habitats no Brasil. Megadiversidade volume 1, $\mathrm{n}^{\circ} 1$, junho- 2005.

Lourenço, W.R.; Eickstedt, V. R. Escorpiões de Importância Médica. In: Brazil T.K.; Porto J.P. Os Escorpiões, EDUFBA, Salvador-BA, 2009.

Ministério da Saúde. Portal da Saúde. Sistema de Informação de Agravo de Notificação. Datasus. gov.br. acessado em 25/03/2016.

Nabão F.R.; Maruyana A.S. A experiência da enfermidade e o itinerário terapêutico vivenciado por uma pessoa com infarto.Revista Eletrônica de Enfermagem. Cuiabá-MT, 2006.

Neto A.M.; Guedes A.B.; Carmo S.F.; Chalkidis H.M.; Coelho J.S.; Pardal P.P.O. Aspectos do escorpionismo no estado do Pará-Brasil. Revista Brasileira de Medicina. V. 22. $\mathrm{n}^{\circ} 1$ Jan/mar, 2008.

Nichiata LYI, Bertolozzi MR, Takahashi RF, Fracolli LA. A utilização do conceito de "vulnerabilidade" pela enfermagem. Ver. Latinoam. Enfrm. 2008;16(5):129-35.

Oguisso, T. Amália - um gigante da Enfermagembrasileira. Enferm. Foco 2017; 7 (3/4): 8185 . 
Pardal, P.P.O.; Castro L.C.; Jenings E.; Pardal J.S.O. Monteiro M.RT.C.C. Aspectos epidemiológicos e clínicos do escorpionismo na região de Santarém, Estado do Pará, Brasil. Revista da Sociedade Brasileira de Medicina Tropical. V. 6 nº 3. p. 353, 2003.

Pardal, P.P.O.; Gadelha M.A.C.; Menezes M.M.G.O.; Malheiros R.S.; Ishikawa E.A.Y; Gabriel M.D.G. Envenenamento grave pelo escorpião TityusobscurusGervais, 1843. Revista Pan-Amaz Saúde, 2014.

Pereira, I. C; Oliveira, M. A. C. Atenção primária, promoção da saúde e o Sistema Único de Saúde: um diálogo necessário. -- São Paulo: Escola de Enfermagem da Universidade de São Paulo,2014.

Polis, G.A.The biology of Scorpions. Stanford: Stanford University Press, 1990a. 587p.

Quispe Torrez, P.P. Estudo clínico epidemiológico laboratorial e de vulnerabilidade dos acidentes escorpiônicos no Hospital Municipal de Santarém-Pará. São Paulo, 2016.

Rosa, L.M. da. El cuidado de enfermería enel itinerario terapêutico de la persona conel diagnóstico del cáncer. 2007. Florianópolis. 120 p. Disertación (Maestria em Ernfermería) Programa de Pós-Graduación em Enfermería, Universidad Federal de Santa Catarina.

Sánchez M.A.I.; Bertolozzi M.R. Pode o conceito de vulnerabilidade apoiar a construção do conhecimento em Saúde Coletiva? Ciências e Saúde Coletiva. V. 12. nº 2. p. 319-324, 2007.

Silva D.C; Schimith M.D; Rizzatti S.J; Simon B.S; Robaina M.L. Itinerário Terapêutico: tendência em teses e dissertações da enfermagem no Brasil. Saúde, Santa Maria vol.40, n.1, jan/jul, p.21-30, 2014.

Solegland, M.E; Azevedo, V. 2003.High level systematics and phylogeny of the extant scorpions (Scorpiones: Orthosterni). Eucorpius 11:1-175.

TorrezP.P.Q. ;Quiroga M.M.M. ; Abati P.A.M.; Mascheretti M.; Costa W.S.; Campos L.P.; França F.O.S. Acute cerebellar dysfunction with neuromuscular manifestation after scorpionism presemably caused by tityus obscurus in Santarém, Pará/ Brasil. Toxicon 96 (2015) 68-73. São Paulo-SP.

Velho, G. Projeto e Metamorfose: antropologia das sociedades complexas. Rio de Janeiro. Jorge Zahar, 1994.

Zocal, Karina Furiani. A peçonha do escorpião Tityusserralatus é reconhecida por receptores de reconhecimento padrão $e$ induz ativação celular e inflamação. Universidade de São Paulo: Faculdade de Ciências Farmacêuticas de Ribeirão Preto, 2014. 
APÊNDICES 


\section{APÊNDICE A \\ INSTRUMENTO DE COLETA DE DADOS}

\section{ITINERÁRIO TERAPÊUTICO DAS VÍTIMAS DO ESCORPIÔNISMO ATENDIDAS NO PRONTO MUNICIPAL DE SANTARÉM, PA.}

Entrevista realizada com o paciente? Se resposta negativa, quem

respondeu o questionário?

\section{IDENTIFICAÇÃO DO PACIENTE}

1.1.Número do prontuário no HMS: Data de internação

1.2. $\mathrm{N}^{\mathrm{o}}$ da entrevista:

1.3. Qual o nome do senhor (a )? (ou como o senhor (a) se chama?)

Nome (somente as iniciais):

1.4. Quando o senhor (a) nasceu? Data de Nascimento: ou Idade:

\subsection{Sexo1.Masc( )2.Fem( )}

1.6. Estado civil:solteiro( ) casado/amasiado( ) separado/divorciado( ) viúvo( )

1.7. Você tem alguma crença religiosa? ( ) sim Qual?. ( ) não

1.8. O senhor(a) mora prá onde? (ou onde o senhor(a) mora? Ou onde o senhor(a) reside?)

Procedência atual (colocar o nome e o número da rua em que mora, da comunidade, do município e ponto de referência próximo de sua casa):

1.9. O senhor(a) estudou? $\operatorname{Sim}($ ) Não( )

Em caso de resposta afirmativa: O senhor (a) estudou durante quantos anos?

Escolaridade/Anos de estudo concluídos: ( )nenhum ( ) Alfabetizado
( ) 1 a 3
( ) 4 a 7
( ) 8 a 11
( ) $12 \mathrm{e}+$
( )não sabe

1.10. Profissão:.

1.11. Local do Acidente (colocar o nome e o número da rua, ou o nome da comunidade, o nome do município e o ponto de referência mais próximo em que ocorreu o acidente):

Acidente Anterior: ( ) sim ( ) não

Local da Picada: ( ) mão ( ) pé ( ) dedos ( ) outro Qual

Data / hora Acidente:

Data / hora Início dos Síntomas:

Data / hora Admissão:

I_

Data da Alta Hospitalar: às

às
h

Trouxe Animal Para Identificação: ( ) $\overline{\operatorname{sim}}$ ( ) não

Descrição do Animal (cor):

Fotografou o animal ( ) e ou filmou o paciente ( ) Identificar com No do prontuário

Nome popular do animal:

2. Dados sócio-econômicos

2.1 Atualmente, o Sr.(a) trabalha fora de casa? 1.( ) sim 2.( ) não 
Em que o Sr.(a) trabalha?

Quantas horas por dia/semana o Sr.(a) trabalha?

O Sr.(a) tem carteira de trabalho assinada? 1. ( )sim 2.( ) não

O Sr.(a) está desempregado ? 1. ( ) sim 2. ( ) não

Há quanto tempo o Sr.(a) está desempregado?

Como o Sr.(a) se sustenta sem seu emprego?

( ) aposentado

2.2 Como e com quem o Sr.(a) vive:

( )sozinho(a) ( )albergue ( )na rua ( )com alguém.

Quantas pessoas moram com o Senhor(a)?

Sua casa é: ( )própria ( )alugada ( )financiada （ ) cedida

( ) instituição (asilar/abrigo) ( ) não tem moradia ( ) outro.....

( ) de alvenaria ( ) de madeira ( ) barraco

( ) outro

Tem quantos cômodos?

( ) 1 cômodo ( ) 2 cômodos ( )3 cômodos ( )4 cômodos ( )5 ou mais cômodos

Que benefícios tem a sua casa?
( ) luz elétrica
( ) asfalto
( ) poço
( ) água encanada
( ) rede de esgoto
( ) coleta de lixo.
vezes por semana

2.3 O Sr.(a) considera que o recurso financeiro que você ou sua família dispõe é:
( ) suficiente para morar
( ) insuficiente para morar
( ) suficiente para comer
( ) insuficiente para comer
( ) suficiente para transporte
( ) insuficiente para o transporte
( ) suficiente para o lazer
( ) insuficiente para o lazer
( ) suficiente para o vestuário
( ) insuficiente para o vestuário
( ) Por favor, explicar a sua resposta

2.4 Quando o Sr.(a) está doente, qual é o serviço de saúde que você mais procura:

( ) Serviço de saúde público. Qual (is)?.

( ) Serviço de saúde privado. Qual (is)?

\section{Qual é o meio de transporte que o Sr.(a) mais utiliza?}

( )ônibus ( ) carro próprio ( ) bicicleta ( ) moto ( ) barco

( ) lancha ( )outros.

\section{AVALIAÇÃO DO QUADRO CLÍNICO}

A avaliação do paciente será feita na admissão e diariamente, no período da manhã, até a remissão do quadro clínico

AVALIAÇÃO DA INTENSIDADE DA DOR NA ADMISSÃO ( 0 a 10), em criança avaliação através das cores.

1,Teve dor no local da picada: Sim ( ) Não ( ). Se sim quanto minutos após a picada?

0 a 15 minutos ( ) 16 a 30 minutos ( ) mais de 30 minutos ( ) mais de 1 hora ( ) 


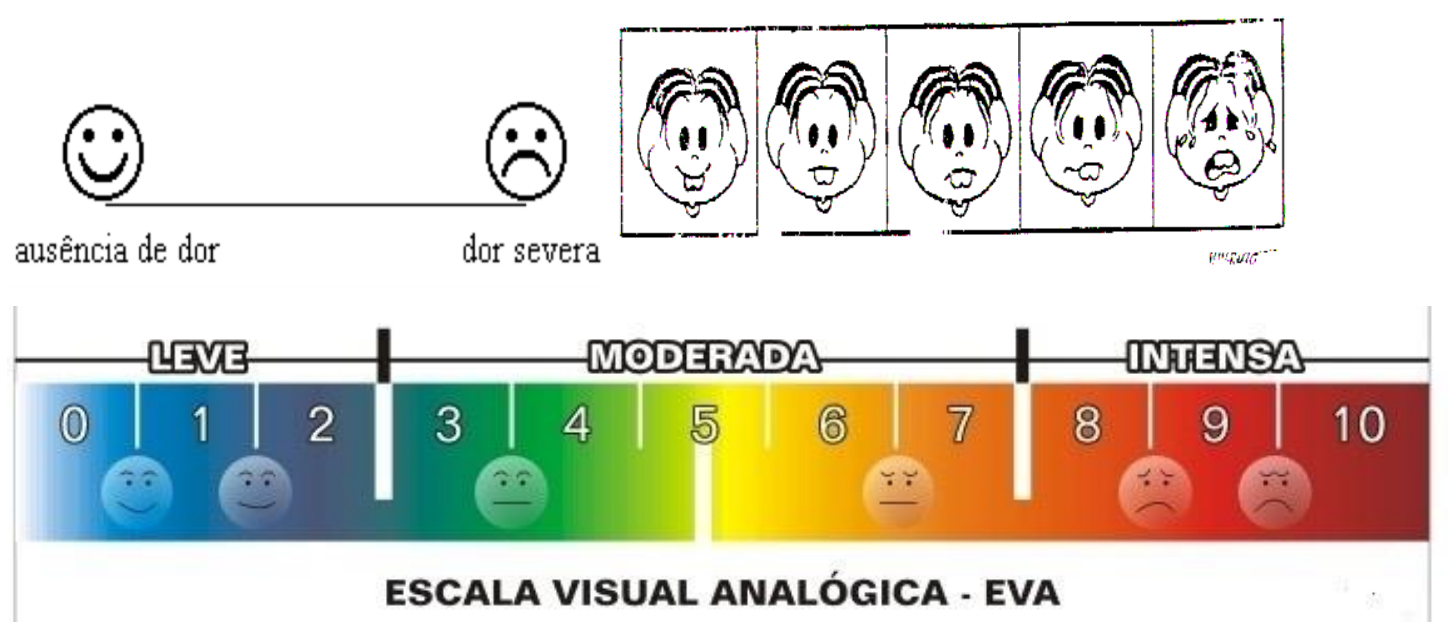

1. Teve "choques elétricos" pelo corpo: Sim ( ) Não ( ). Se sim quanto minutos após a picada?

1. - 15 minutos ( ) 16 - 30 minutos ( ) mais de 30 minutos ( ) mais de 1 hora ( )

2.Teve dificuldade para caminhar: Sim ( ) Não ( ). Se sim quantos minutos após a picada?

0 - 15 minutos ( ) 16 - 30 minutos ( ) mais de 30 minutos ( ) mais de 1 hora ( )

3.Teve dificuldade para falar (a língua ficou enrolada?): Sim ( ) Não ( ). Se sim quanto minutos após a picada?

1. -15 minutos ( ) 16- 30 minutos ( ) mais de 30 minutos ( ) mais de 1 hora ( )

\section{MANIFESTAÇÕES LOCAIS NA ADMISSAO:}

Dor ( ) sim ( ) não Edema ( ) sim ( ) não Eritema ( ) sim ( ) não $\quad$ Calor local ( ) $\operatorname{sim}$ ( ) não Piloereção ( ) sim ( ) não

Sudorose Local ( ) sim ( ) não Parestesia ( ) sim ( ) não

Dor na região proximal do membro picado ( ) sim ( ) não Outros ( ) sim ( ) não Qual

MANIFESTAÇÕES

Tremores ( ) sim ( ) não

Astenia ( ) sim ( ) não

\section{SISTÊMICAS}

Prostração ( ) sim ( ) não

Hipertermia ( ) sim ( ) não

MANIFESTAÇÕES CLÍNICAS (AUTONÔMICAS):

Taquicardia ( ) sim ( ) não Bradicardia ( ) sim ( ) não

Hipertensão ( ) sim ( ) não Hipotensão ( ) sim ( ) não

Sudorese ( ) sim ( ) não Náuseas ( ) sim ( ) não

Vômitos ( ) sim ( ) não

Diarréia ( ) sim ( ) não

Sialorreia ( ) sim ( ) não Priaprismo ( ) sim ( ) não

Eupneico ( ) sim ( ) não Acianotico ( ) sim ( ) não CONDIÇÕES DE ALTA HOSPITALAR : Cura ( ) óbito ( ) OBSERVAÇÃO: 


\section{APÊNDICE B \\ INSTRUMENTO DE COLETA DE DADOS \\ ENTREVISTA DA VÍTIMA DE ESCORPIONISMO ATENDIDA NO PRONTO SOCORRO MUNICIPAL DE SANTARÉM}

\section{Trajetória percorrida pela davítimado acidente escorpiônico.}

1. Soubemos que o Sr.(a) foi picado por um escorpião, poderia nos contar como aconteceu o acidente?

2. O que o Sr. (a) fez com o escorpião que lhe causou o acidente? Trouxe para o hospital? $\operatorname{Sim}($ ) Não( ) por que?

3. O Sr. (a) teve ajuda de alguém após a picada? $\operatorname{Sim}(\quad$ ) não( ). De quem?

4. O que foi feito no local da picada? Curou com algum medicamento natural ou tomou medicamento natural? Qual?

5.O que o Sr.(a) sentiu após a picada?

6. Encontrou dificuldade pra chegar até aqui? Sentiu medo? 


\section{APÊNDICE C \\ TERMO DE CONSENTIMENTO LIVRE E ESCLARECIDO (TCLE)}

Convido o senhor(a) a participar da pesquisa intitulada "Itinerário Terapêutico da vítima do escorpionismo atendido no Hospital Municipal de Santarém", que é coordenada pelo Profo. Dro. Francisco Oscar de Siqueira França, docente do Programa de Pós-Graduação da Escola de Enfermagem da USP. Meu nome é Erli Marta Reis da Silva, sou aluna do programa de pós-graduação em Mestrado Profissional em Enfermagem na Atenção Primária, da Escola de Enfermagem da Universidade do Estado de São Paulo, e sou a responsável pela pesquisa que será realizada.

O objetivo da pesquisa será identificar as dificuldades encontradas pela vítima de picada de escorpião, quando precisa procurar atendimento e tratamento, através da experiência do acidente, desde o momento da picada até o atendimento e tratamento oferecido. Os resultados do trabalho servirão para melhorar os serviços de saúde oferecidos a vítima de picada de escorpião no Município de Santarém-PA.

Para que a pesquisa seja realizada, solicito sua participação, caso o senhor(a) aceite, responderá dois questionários. O primeiro,será uma entrevista gravada, com perguntas sobre o acidente e quais foram as dificuldades encontradas na trajetória que o senhor(a) percorreu até seu atendimento e tratamento. A entrevista terá duração de 30 minutos e será realizada em um lugar reservado, para o senhor(a) se sentir mais a vontade. O outro questionário será um formulário, preenchido a caneta, pelo médico que examinar o senhor(a) acompanhado pela responsável da pesquisa, ou por um enfermeiro participante, enquanto estiver internado ou em observação, terá duração de 20 minutos, o senhor(a) responderá informações pessoais e o relato das reações que o acidente pode ter causado no seu corpo.

Se o senhor(a) permitir, também será registrado imagens através de fotografias, do momento da entrevista, do local da picada de escorpião e do próprio escorpião, caso tenha sido capturado e trazido para o hospital, para enriquecer os resultados da pesquisa.

Sua participação é voluntária, podendo recusar-se a responder quaisquer perguntas, e sua recusa não trará nenhuma penalidade ou prejuízo em sua relação com o pesquisador, nem com a equipe que estiver lhe atendendo. Informamos ainda que o Senhor(a) não terá nenhum custo ou qualquer compensação financeira em qualquer fase da pesquisa. Caso ocorra algum dano financeiro ou físico ao senhor (a) relacionado à pesquisa, o senhor (a) será ressarcido, ou seja, a responsável pela pesquisa arcará com as despesas. O beneficio relacionado à participação do senhor(a) será de aumentar o conhecimento dos profissionais de saúde que trabalham nas unidades básicas e hospitalares, e na melhoria do atendimento a vitima da picada do escorpião em nossa região, para diminuir as dificuldades encontradas pelo usuário na busca pelo atendimento. O possível risco será do senhor(a) não entender e se sentir constrangido em responderas perguntas que serão feitas, caso isso aconteça, poderá nos dizer e nós explicaremos de forma que o senhor entenda melhor e se sinta a vontade para falar.

O senhor(a) não será identificado, ou seja, seu nome não aparecerá em nenhum momento. Estamos a sua disposição, para esclarecer qualquer duvida. O senhor poderá me 
encontrar, na Universidade do Estado do Pará (UEPA) onde trabalho como professora, no curso de medicina, que fica localizada na Av: Plácido de Castro, $\mathrm{n}^{\circ}$ 1399, Aparecida, CEP: 68040-090, Fone:(93)3512-8000 ou pelo meu celular (93) 99190-2266 e email: erlimartareis@ hotmail.com.

Esta pesquisa atende todas as especificações da Resolução 466, de 12 de dezembro de 2012, que aprova as diretrizes e normas regulamentadoras de pesquisas envolvendo seres humanos.

Este projeto de pesquisa foi aprovado pelo Comitê de Ética em Pesquisa (CEP) Endereço - Av. Dr. Enéas de Carvalho Aguiar, 419 - Cerqueira Cesar - São Paulo/SP CEP 05403-000 Telefone- (11) 30618858 e-mail - cepee@usp.br. Caso o Sr.(a) tenha alguma dúvida ou queira algum esclarecimento sobre a ética da pesquisa, pode entrar em contato com o Comitê de Ética mencionado acima.

Santarém/Pará de de 2016

Assinatura do sujeito da pesquisa 


\section{APÊNDICE D \\ TERMO DE ASSENTIMENTO PARA MENORDE IDADE}

Você está sendo Convidado(a) a participar da pesquisa intitulada "Itinerário Terapêutico das vítimas do escorpionismo atendidas no Hospital Municipal de Santarém", seus pais permitiram que você participe, o estudo é coordenado pelo Prof. Dr. Francisco Oscar de Siqueira França, professor do Programa de Pós-Graduação da Escola de Enfermagem da USP. Meu nome é Erli Marta Reis da Silva, sou aluna do programa de pósgraduação em Mestrado Profissional em Enfermagem na Atenção Primária, da Escola de Enfermagem da Universidade de São Paulo, e sou a responsável pela pesquisa que será realizada.

O objetivo da pesquisa será de saberas dificuldades encontradas por pessoas que precisam procurar atendimento e tratamentoquando são picadas por escorpião, desde o momento do acidente até o atendimento e tratamento no hospital. Os resultados do trabalho servirão para melhorar os atendimentos às pessoas que sãopicadas por escorpião em Santarém-PA e comunidades vizinhas.

Todas as crianças que forem picadas por escorpião e atendidas aqui no hospital no período da pesquisa, serão convidadas a participar.Caso você aceite, os seus pais ou responsável, junto com você, responderão algumas perguntas. Será uma conversa gravada, com perguntas sobre o acidente e como foi o caminho quevocê e seus pais ou responsávelfizeram até chegarem aqui no hospital para serem atendidos. A entrevista terá duração de 30 minutos e será realizada em um lugar reservado, para você e seus pais ou acompanhante se sentirem mais a vontade.

$\mathrm{O}$ outro questionário será um formulário, preenchido à caneta, pelo médico que cuidará de você acompanhado pela responsável da pesquisa, ou por um enfermeiro participante, e terá duração de 20 minutos. Você, junto com seus pais ou acompanhantes, irão responder perguntas, como seu nome completo, onde você mora, se você sente ou sentiu algum mal-estar no seu corpo, por causa da picada do escorpião. Se você permitir, também serãoregistradas imagens com fotografias, do momento da entrevista, do local da picada do escorpião e do próprio escorpião, caso tenha sido capturado e trazido para o hospital, para enriquecer os resultados da pesquisa.

Você não precisa participar da pesquisa se não quiser, é um direito seu. Não terá nenhum problema se desistir, nem com o pesquisador, nem com os médicos, enfermeiros e outros profissionais que estiverem lhe atendendo.Você continuará sendo cuidado da mesma forma. Informamos ainda que você e seus pais ou responsável não terão que pagar nada e nem receberão nenhum benefício, como dinheiro por exemplo, para participar da pesquisa.

Caso ocorra algum dano financeiro ou físico a você relacionado à pesquisa, você será ressarcido, ou seja, a responsável pela pesquisa pagará as despesas.O benefício relacionado à sua participação será de aumentar o conhecimento dos profissionais de saúde que atendem nos postos e hospitais, e para que as pessoas que são picadas por escorpião sejam bem atendidas. As perguntas não serão difíceis de entender, mas pode ocorrer o risco de você e 
seus pais ou acompanhantes não entenderem ese sentirem constrangidos em responder as perguntas que serão feitas; caso isso aconteça poderá nos dizer e nós explicaremos de forma que você, seus pais ou acompanhantes entendam melhor e se sintam a vontade para falar.

Ninguém saberá que você participou da pesquisa, ou seja, seu nome não aparecerá em nenhum momento. Estamos àdisposição de você e seus pais ou acompanhantes, para esclarecer qualquer dúvida. Você e seus pais ou responsável poderão me encontrar na Universidade do Estado do Pará (UEPA), onde trabalho como professora, no curso de medicina, que fica localizada na Av: Plácido de Castro, no 1399, Aparecida, CEP: 68040-090, Fone:(93)3512-8000 ou pelo meu celular (93) 99190-2266 e email: erlimartareis@ hotmail.com.

Esta pesquisa atende todas as especificações da Resolução 466, de 12 de dezembro de 2012, que aprova as diretrizes e normas regulamentadoras de pesquisas envolvendo seres humanos.

Este projeto de pesquisa foi aprovado pelo Comitê de Ética em Pesquisa (CEP) Endereço - Av. Dr. Enéas de Carvalho Aguiar, 419 - Cerqueira Cesar - São Paulo/SP CEP 05403-000 Telefone- (11) 30618858 e-mail - cepee@usp.br. Caso você, seu seus pais ou responsável tenham alguma dúvida ou queiram algum esclarecimento sobre a ética da pesquisa, podem entrar em contato com o Comitê de Ética mencionado acima.

Santarém/Pará de de 2016

Assinatura do menor / sujeito da pesquisa

Assinatura do acompanhante / responsável

Assinatura do Pesquisador 


\section{APÊNDICE E}

$\mathrm{O}$ apêndice $\mathbf{E}$ corresponde às 18 entrevistas, transcritas na íntegra, e gravadas em 2 CDs anexados aos exemplares desta pesquisa. Foi preservada a expressão oral dos sujeitos, que é peculiar ao homem do campo da região local. 
ANEXOS 


\section{ANEXO A \\ CARTA DE ACEITE}

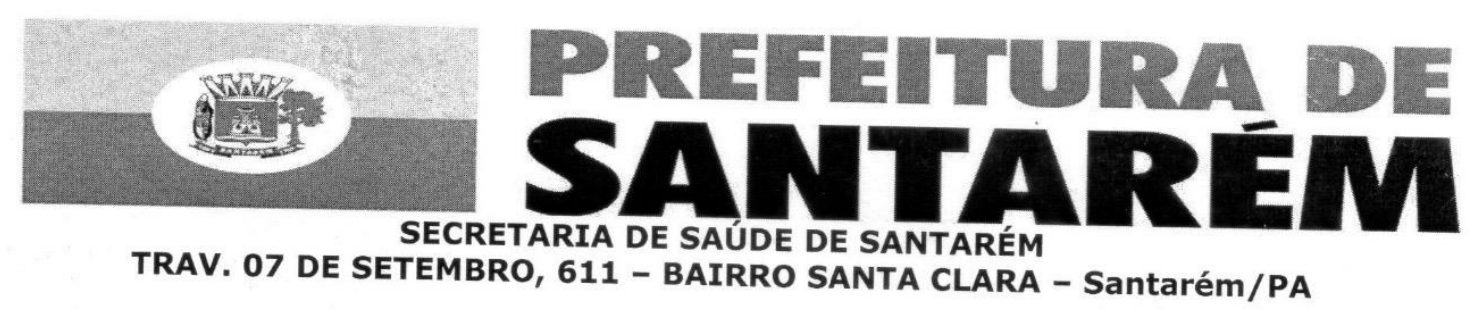

CARTA DE ACEITE

Em nome da Secretaria Municipal de Saúde, declaro ter conhecimento do projeto de pesquisa intitulado "ITINERÁRIO TERAPÊUTICO DAS VÍTIMAS DE ESCORPIONISMO ATENDIDAS NO HOSPITAL MUNICIPAL DE SANTARÉM (PARÁ)" de autoria da Docente da Universidade do Estado do Pará, e aluna do Programa de Pós Graduação em Mestrado Profissional da Escola de Enfermagem da Universidade de São Paulo- USP, Erli Marta Reis da Silva, dando-Ihe consentimento para realizar o trabalho nesta instituição/ Hospital Municipal de Santarém e coletar dados em nosso serviço, após a aprovação do projeto em questão ao Comitê de Ética, o qual é pré-requisito para o início da pesquisa.

Necessário, porém, se faz que antes da publicação dos resultados o trabalho seja apresentado a esta Secretaria Municipal de Saúde com o escopo de analisar e discutir os resultados obtidos, sendo obrigatório citar na publicação o nome da Universidade do Estado do Pará- UEPA e da Secretaria Municipal de Saúde, como locais de realização da pesquisa.

Santarém, 12 de Julho de 2016.

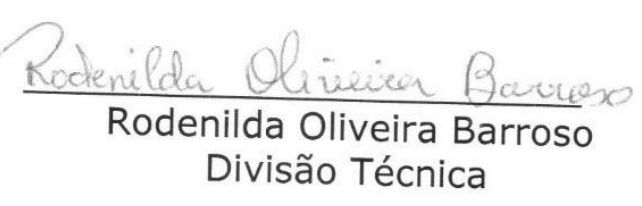




\section{ANEXOB \\ CARTA DE ACEITE}

HOSPITAL

MUNICIPAL

DE SANTARÉM
Av. Pres. Vargas, N. 1539 - Santa Clara - CEP 68005-110 CNPJ Q5.182.233/0001-76 Fone: 3523 - 2155 / Fax: 35232175 hmssemsa.stm国gmail.com

\section{CARTA DE ACEITE INSTITUCIONAL}

Em nome do Hospital Municipal de Santarém (HMS), declaro ter conhecimento do projeto de pesquisa intitulado "ITINERÁRIO TERAPÊUTICO DAS VÍTIMAS DE ESCORPIONISMO ATENDIDAS NO HOSPITAL MUNICIPAL DE SANTARÉM (PARÁ)", de autoria da pesquisadoraErli Marta Reis da Silva,pós-graduanda do curso de Mestrado Profissional em Enfermagem na Atenção Primária no Sistema Único de Saúde da Escola de Enfermagem da Universidade de São Paulo, dando-lhe consentimento para execução do projeto de pesquisa para fins de produção daDissertação de Mestrado, a coleta de dados consiste em entrevista compacientes vítimas de acidentes escorpiônicos e dados de aspectos clínico-epidemiológicos a partir um questionário aplicado aos pacientes, e informações contidas na ficha de notificação e prontuários de pacientesque aceitarem participar da pesquisa de livre vontade e assinarem o Termo de Consentimento Livre e Esclarecido (TCLE).As entrevistas e coleta de dados, poderão ser realizadas preferencialmente no horário de 7:00 as 22:00 horas, no período de $1^{\circ}$ de Novembro de 2016 a 28 de Fevereiro de 2017 , desde que acordadas previamente com as participantes da pesquisa, no tempo máximo de 30 min para que nãose tornem exaustivas.

Necessário, porém se faz, que antes da apresentação e ou publicação dos resultados, o trabalho final seja apresentado a esta Instituição Hospitalar com o escopo de analisar e discutir os resultados obtidos, ficando em caráter obrigatório a citação da Universidade de São Paulo e do Hospital Municipal de Santarém, como locais de realização da pesquisa.

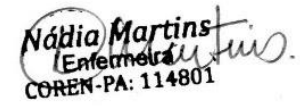

Enf. Msc. Nádia Vicência do Nascimento Martins (93) 991453053 -stm.martins@hotmail.com Setor de Educação Continuada

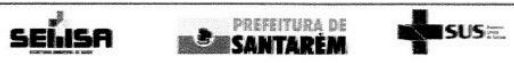

